Illinois State University

ISU ReD: Research and eData

Theses and Dissertations

$11-9-2021$

\title{
Say Her Name: The Narrative Afterlives of Breonna Taylor
}

Tyler S. Smith

Illinois State University, pocashea97@gmail.com

Follow this and additional works at: https://ir.library.illinoisstate.edu/etd

\section{Recommended Citation}

Smith, Tyler S., "Say Her Name: The Narrative Afterlives of Breonna Taylor" (2021). Theses and Dissertations. 1506.

https://ir.library.illinoisstate.edu/etd/1506

This Thesis is brought to you for free and open access by ISU ReD: Research and eData. It has been accepted for inclusion in Theses and Dissertations by an authorized administrator of ISU ReD: Research and eData. For more information, please contact ISUReD@ilstu.edu. 


\section{SAY HER NAME: THE NARRATIVE AFTERLIVES OF BREONNA TAYLOR}

\section{TYLER S. SMITH}

\section{Pages}

Within the growing literature and media coverage of police misconduct and brutality, Black women and girls are functionally invisible. Since the Black Lives Matter movement began the names of only two women have stood out among the Black male victims we know by name: Sandra Bland and Breonna Taylor. Here, I will explore through a Black feminist analytic framework, how the intersectionalities of gender and race contributed to a delay in awareness and accountability for the death of Breonna Taylor. This content analysis looked at the media coverage of Breonna Taylor for the one-year period (3/13/20-3/13/21) to uncover the reasons, implications, and usage of the resurrected story of Breonna Taylor following the death of George Floyd, to explain why her life and legacy only seems to matter because his did. The narrative afterlives of Breonna Taylor detail the implications of an empty activism; what happens when a name becomes the only thing we are saying? Secondarily, this thesis answers how and why she became the first Black woman martyred by the Black Lives Matter movement.

KEYWORDS: Breonna Taylor, Black feminism, decolonial theory, Black Lives Matter, Say Her Name 
SAY HER NAME: THE NARRATIVE AFTERLIVES OF BREONNA TAYLOR

TYLER S. SMITH

A Thesis Submitted in Partial

Fulfillment of the Requirements

for the Degree of

MASTER OF SCIENCE

Department of Criminal Justice Sciences

ILLINOIS STATE UNIVERSITY

2021 
(C) 2021 Tyler S. Smith 
SAY HER NAME: THE NARRATIVE AFTERLIVES OF BREONNA TAYLOR

TYLER S. SMITH

COMMITTEE MEMBERS:

Dawn Beichner, Chair

Jessie Krienert

Phill Mulvey 


\section{ACKNOWLEDGMENTS}

This thesis is dedicated to the memories of the women of color who senselessly suffered and lost their lives too soon due to the state's indifference to their lives through physical and political white supremacist violence and logics. Notably:

My beloved grandmother Tanh Chhay (1947-2018) whose eternal love and support in life gave me the courage and determination to be the first college graduate in the family, and

ultimately, pursue systemic change and this degree. And whose needlessly tragic death gave me the perspective that the only way I could meaningfully change the system was by applying pressure on it from the outside.

Breonna Taylor (1993-2020), whose death by police highlighted the perpetual insecurity being a Black woman places on your life, regardless of education and engagement in white respectability frameworks; inspiring millions around the world to speak up.

By no means curative on its own, this thesis is intended to restore some of the dignity that was taken from these victims by the state. It is my intent to use this thesis to exercise my privilege as a living Black woman to speak up and advocate for those who have faced victimization and lack a voice and the ability to secure justice on their own.

I'd like first to extend my thanks to my amazing thesis chair Dawn Beichner, who has inspired me and helped to shape my decision to go into this field of study, listening to me complain about the world around me since 2018 , I cannot begin to voice the ways in which you have shaped my conceptions of the world and its phenomena, nor my decision to pursue a career in criminal justice, I am eternally grateful and appreciative of you. To Drs. Jessie Krienert and Phill Mulvey who so graciously agreed to serve as committee members on this project. 
To the friends and family who were made to listen to my many rants and frustrations with this project, I sincerely thank you. My brother Jordan Smith for all the 4 a.m. phone calls when I was falling apart and did not believe I would ever finish this project. My father Duane Smith who endlessly talked shop with me about policing, answering all my questions and entertaining scenarios. My mother Amanda Dy for reminding me to practice self-care. My best friend Bethany Peppers, who has inspired and encouraged me every day for the past 10 years, by strengthening my convictions forcing me to defend such things as Black feminism over womanism.

And finally, to the amazing Black femme scholars, writers, and activists: Michelle Alexander, Christina Sharpe, Saidiya Hartman, Audre Lorde, Kimberlè Crenshaw, Andrea Ritchie, Carol Anderson, Sylvia Winter, Brittney Cooper, Tiffany Lethabo King, and Reni EddoLodge, to name a few, whose works haunted me intellectually, giving me no choice but to pursue a career in academia.

T.S.S. 


\section{CONTENTS}

Page

$\begin{array}{ll}\text { ACKNOWLEDGMENTS } & \text { i }\end{array}$

TABLES vii

FIGURES Viii

CHAPTER I: INTRODUCTION 1

Statement of the Problem 1

$\begin{array}{ll}\text { Description and Purpose of Study } & 7\end{array}$

CHAPTER II: LITERATURE REVIEW 12

*Knowing While Black 13

Decolonization: Towards the Radical Re-Imagining of The Victim/Offender Relation 15

A Brief History of Decolonial Ideas 15

$\begin{array}{lr}\text { The Decolonized Dialectic } & 18\end{array}$

$\begin{array}{ll}\text { A Decolonial Criminology } & 21\end{array}$

$\begin{array}{ll}\text { Black Feminism as Inquiry } & 24\end{array}$

$\begin{array}{ll}\text { Say Her Name } & 27\end{array}$

Gore Capitalism: The Aesthetic and Discursive Practices of State Anti-Blackness 29

$\begin{array}{ll}\text { Decolonizing The Past } & 30\end{array}$

Mortgaging Black Bodies: Race, Capital, Policing, And White Supremacy $\quad 31$

A Mandate to Kill? $\quad 34$

Carceral Capitalism and Mass Incarceration 36

Framing Mass Incarceration as State Anti-Blackness 38

$\begin{array}{ll}\text { Carceral Capitalism } & 39\end{array}$

The Faces of Carceral Capitalism and Mass Incarceration 40

$\begin{array}{ll}\text { The Drug War } & 40\end{array}$ 
Because He Was Scary-Police Violence Against Black Men

I Can't Breathe: An American Saga 48

The Double Death of The Black Body 50

Because She Was Scary—State Violence Against Black Women 52

Patterns Of Police Violence Against Black Women 53

$\begin{array}{ll}\text { Police Sexual Assault } & 53\end{array}$

Black Women Under Stop and Frisk $\quad 54$

Driving While Superhumanly Black $\quad 54$

Casualties of The Drug War: Black Women As “Collateral Damage” 55

"I Hate That She Had to Die to Be Great:” Breonna Taylor's Legacy as The First Black

$\begin{array}{ll}\text { Woman Martyr } & 55\end{array}$

$\begin{array}{ll}\text { CHAPTER III: METHODS } & 60\end{array}$

$\begin{array}{ll}\text { The Study } & 60\end{array}$

$\begin{array}{ll}\text { Content and Discourse Analyses } & 61\end{array}$

$\begin{array}{ll}\text { Research Question } & 62\end{array}$

$\begin{array}{ll}\text { Hypotheses } & 62\end{array}$

$\begin{array}{ll}\text { Hypothesis Testing and Measurement } & 62\end{array}$

$\begin{array}{ll}\text { Data } & 63\end{array}$

$\begin{array}{ll}\text { Methods and analysis } & 64\end{array}$

$\begin{array}{ll}\text { Reliability } & 66\end{array}$

CHAPTER IV: RESULTS: THE SEVEN NARRATIVE AFTERLIVES OF BREONNA

$\begin{array}{ll}\text { TAYLOR } & 68\end{array}$

Understanding the Killing of Breonna Taylor $\quad 69$

Framing Breonna: Unpacking the Media Narrative Afterlives of Breonna Taylor $\quad 73$ 
The Seven Narrative Afterlives of Breonna Taylor $\quad 76$

Afterlife 1: Breonna the Ideal Black Victim 78

$\begin{array}{ll}\text { Assigned Value } & 79\end{array}$

$\begin{array}{ll}\text { Innocence } & 80\end{array}$

Afterlife 2: Breonna the Victim of a Failed Police Raid 82

$\begin{array}{ll}\text { Afterlife 3: Breonna the Meme } & 85\end{array}$

Politician Activism, Celebrity Activism, and "Arrest the Cops" 86

Say Her Name, BLM, and References to Black Male Victims 88

Honoring Breonna $\quad 89$

Afterlife 4: \#(In)Justice for Breonna: Breonna the Victim of Injustice 90

Police Reform \& Accountability $\quad 91$

Nationwide Policing Practices $\quad 92$

Afterlife 5: Breonna the Catalyst of Retaliatory Violence 93

$\begin{array}{ll}\text { Retaliatory Violence I } & 93\end{array}$

Retaliatory Violence II $\quad 94$

$\begin{array}{ll}\text { Double Death } & 95\end{array}$

Afterlife 6: Breonna the Victim of Performative Justice 96

Lack of Police Accountability and LMPD Take No Responsibility 97

$\begin{array}{ll}\text { Systemic Failures } & 97\end{array}$

$\begin{array}{lr}\text { Larger Government Corruption } & 98\end{array}$

Performative Justice $\quad 99$

$\begin{array}{ll}\text { Afterlife 7: Breonna the Inspiration of Change } & 102\end{array}$

Summary of Results: Hypotheses Revisited 107

$\begin{array}{ll}\text { Hypothesis } 1(\mathrm{H} 1) & 107\end{array}$

$\begin{array}{ll}\text { Hypothesis } 2(\mathrm{H} 2) & 107\end{array}$

$\begin{array}{lr}\text { Summary } & 108\end{array}$ 
CHAPTER V: CONCLUSION: WHAT BRE LEFT BEHIND: THE LEGACY OF BREONNA

$\begin{array}{ll}\text { TAYLOR } & 110\end{array}$

$\begin{array}{ll}\text { The Seven Narrative Afterlives in Context } & 110\end{array}$

$\begin{array}{ll}\text { Aspiration } & 116\end{array}$

$\begin{array}{ll}\text { Future Studies } & 117\end{array}$

$\begin{array}{ll}\text { Policy Recommendations } & 117\end{array}$

$\begin{array}{ll}\text { Imagine } & 119\end{array}$

$\begin{array}{ll}\text { REFERENCES } & 122\end{array}$

$\begin{array}{ll}\text { APPENDIX A: CODES AND FREQUENCIES } & 165\end{array}$

APPENDIX B: BREONNA'S EMBEDDEDNESS IN THE NARRATIVE 167 


\section{TABLES}

Table

Page

1. Article Result Frequency and Date Dispersion 


\section{FIGURES}

Figure $\quad$ Page

$\begin{array}{ll}\text { 1. Concept Map } & 77\end{array}$

$\begin{array}{ll}\text { 2. Afterlife } 1 \text { Code Tree } & 78\end{array}$

3. Afterlife 2 Code Tree $\quad 82$

4. Afterlife 3 Code Tree 85

5. Afterlife 4 Code Tree 90

6. Afterlife 5 Code Tree 93

7. Afterlife 6 Code Tree 96

8. Afterlife 7 Code Tree 102 


\section{CHAPTER I: INTRODUCTION}

"When we revolt it's not for a particular culture. We revolt simply because, for many reasons, we can no longer breathe"

-Frantz Fanon ([[1970] 1994, 50] Sharpe, 2016; 111).

\section{Statement of the Problem}

Like countless others around the world, George Floyd also found himself unemployed due to the pandemic, without any material financial relief or assistance from the government, he was desperate and out of options. On May 25th, 2020, he used a counterfeit $\$ 20$ bill, and within 30 minutes he was publicly murdered by the police (BBC, 2020). He felt claustrophobic while being shoved in the back of the police car and stiffened, the officers claimed he was resisting arrest. Shoved on the ground face first, with his hands cuffed behind his back so he could not protect himself, he was still viewed as a threat. Bystanders began interfering, recording the events, and telling officers to get off him; his nose was bloody, and he could not breathe. For six minutes he struggled, pleading for them to let him live. Before he went limp, he remarked out loud that they were going to kill him; he cried out for his mother and for someone to tell his children he loved them. He lay face down silent and unresponsive for two additional minutes under Chauvin's knee before one of the other officers had the sense to check his pulse at the urging of a bystander, and could not find one (BBC, 2020).

In the ensuing hours and days, outrage built, and we grew restless, 140 cities big and small across the U.S. erupted in protest, the National Guard was called in at least 21 states to quell the flow of activism in the wake of the horror and indignation of such an egregious display 
of anti-Blackness (Taylor, 2021). Internationally, amid a pandemic, we took to the streets with signs proclaiming that: "we are all George Floyd," (Daragahi, 2020) vulnerable to the propensity of state violence without end. We realized we had been living our lives holding our breaths, waiting for the moment our name or that of a loved one could join his on the growing list of those we senselessly lost too soon for the simple offense of the color of one's skin.

Tens of thousands in Australia and England defied orders from the health ministry to join in the Black Lives Matter protests, already spanning from Paris to Berlin; in Japan, Sweden and Zimbabwe, Denmark, Italy, Syria, Brazil, Mexico, Canada, Ireland, New Zealand, and Poland all around the world — people left lockdown knowing they could face fines or other legal recourse, and threats to their own personal safety, for defying Covid restrictions in an international act of solidarity (Cave, Albeck-ripka \& Magra, 2020; Rahim \& Picheta, 2020). World leaders also took the opportunity to speak out against police brutality in the United States, Pope Francis himself spoke out in condemnation of the sin of racism in the United States (Povoledo, \& Hauser, 2020). Even autocratic world leaders, responsible for their own gross human rights abuses like Iran's Khamenei spoke up saying:

The fact that a policeman has cold-bloodedly pressed his knee on the throat of a black man until he died and that other policemen watched on without doing anything is nothing new... It is the true face of America, it's what it has always done all over the world... It is the normal course of action of the United States, it's the true face of their regime (CGTN, 2020).

With the eyes of the world on the United States, on the Minneapolis Police Department, material action against police brutality and police anti-Blackness actually had to be taken. Within a week of George Floyd's death, all four involved officers were fired, with the officer inflicting 
the fatal kneel facing murder charges (Taylor, 2021). Attention was then brought to two other deaths argued to also be the result of anti-Blackness that the state ${ }^{1}$ allowed to go unpunished that happened earlier in the spring: the brutal and unnecessary deaths of Ahmad Arbery on February 23, 2020, by vigilantes (Itkowitz, 2020) and Breonna Taylor on March 13, 2020, by the Louisville police (Haines, 2020; De la Cretaz, 2020).

Before the death of George Floyd, Breonna Taylor was just an unnamed "Louisville woman" who was killed during the attempted murder of a police officer (Wise \& Mattingly, 2020). This framing leads the reader to assume she was killed not by one of the brave officers but rather by the male suspect who tried to kill the officer, disregarding her life as well as those of the officers. It is a new spin on the Black-on-Black crime narrative. This story stands in stark contrast to the most mainstream narrative we know have of Breonna Taylor, that of the hero EMT who was killed during a failed raid of her home. This is the immense power of media framing, a form of colonial power this thesis aims to disrupt. This narrative discrepancy and the literature show us that Black ${ }^{2}$ women victims of police violence are invisible not because they are not killed by the police. Not because those killings represent a portion of police brutality cases that it is so nominal it does not merit mention, but because of how they are

\footnotetext{
${ }^{1}$ Here I use "the state" as shorthand in reference to the United States government and its institutions and actors.

${ }^{2}$ The use of "Black" here is in recognition of the forged trauma community necessitated by the horrors of chattel slavery; the legacy of brutal colonial violence that sought to force supplication through extreme vulnerability on the plantations through the shedding of their identities. Turning "Africa" into a cruel metaphor of a home that longer exists. Using Black instead of African American, in order to make visible the way those in the African diaspora, descended from chattel slaves live our lives in the intersection, in the negation and empty symbolism of being abstractly "African" and American in name only. This work takes a dialectical move away from the whitewashing of the history of Blackness in this country. Away from false reconciliation, Black is intended here not only as a typographical change but as a reclamation of the final 2/5ths of our humanity, no longer will we continue to live our lives in the lower case.

The author also chooses here to use "white" in the lowercase instead of in the uppercase in order to highlight the ways in which whiteness has never been a detriment to the pursuit of full citizenship and the rights to life and liberty in this country. Further, white persons have always had access to their heritage, to the ability to point to specific nations of ancestry in a way Black persons never have.
} 
(mis)represented and therefore definitionally excluded from our frameworks of justice and police violence. I, with this thesis intend to help fill in the systemic and institutional imbalances of care here.

Breonna Taylor was 26, an EMT with aspirations of becoming a nurse, yet it took two months for us to even hear about her death when her family filed a wrongful death suit in April, weeks before George Floyd was killed. Even then, her death did not spark the mass outrage and protest, that his inspired (De la Cretaz, 2020; Haines, 2020). It took until May 28th for us to begin saying her name when the first protest surrounding her death was held in Louisville (Flynn, 2020). Breonna Taylor was an invisible victim of the War on Drugs, she was killed as a result of a systematically flawed and problematic drug raid (Glover, et al., 2020). A no-knock search warrant was issued so that the police could just burst into her home unannounced, the goal being to catch the home occupants so off guard that there be no chance of anyone fleeing or destroying drug evidence. There were no drugs in her home. The police claimed they killed her because they feared for their lives after they burst into her home and her boyfriend Kenneth Walker began shooting, standing his ground, protecting his home. They shot blindly into her apartment shooting her at least eight times; killing her (Burke, 2020).

The relative invisibility of Black women victims is underscored here, the death of George Floyd, is where Breonna Taylor's story begins - two months after her death. Her story within our consciousness is inextricable from his, it is not standalone, while George Floyd's story and legacy can be viewed and discussed separate from Breonna Taylor. This is the problem that arises in the intersection of anti-Blackness and misogyny. We see Black women not for who they are but, in the service, or the shadow of Black men. When Black women are killed by the police it is often explained away that they were associated with the wrong men. She was most likely the 
one who opened the door to hostile officers who likely verbally abused and antagonized her, trying to gain access to a male suspect they believe is in the home. Black women are routinely shot out of fear or in the crossfire in their own homes, like Breonna Taylor and so many other unnamed and unrecognized victims of police violence. Black women are routinely not seen as victims because often she was not the primary objective or subject, she was simply collateral damage; forgettable and disposable (Crenshaw, et al., 2015; Ritchie, 2018; McKittrick, 2006). We never hear about these cases because they are framed in the media not as the instances of police brutality they are, but as instances of the police doing their jobs, heroically even, selfdefense.

It took ten months for only two of the officers involved in Breonna Taylor's murder to be fired, but they were not necessarily fired for killing her, it was not justice, it was symbolic and empty (Booker, 2021). Less than a year after what could only be framed as the brutal public execution of George Floyd, Derek Chauvin not only stood trial for his murder, he was also found guilty and sentenced to prison, while not a single officer has even been charged with personal or criminal responsibility in the death of Breonna Taylor (Hill, et al., 2020; Bogel-Burroughs, 2021). Instead, the city of Louisville, namely the taxpayers of Louisville, accepted civil and financial responsibility for the events that transpired when her family won the wrongful death suit filed in May awarding them $\$ 12$ million (Morales, et al., 2020). The extant literature suggests this is because police killings of Black people are, on balance, the result of statesanctioned violence not subject to due process. This is evidenced in the way that officers who kill unarmed Black persons rarely see their day in court due to qualified immunity and the rationale that policing is dangerous and therefore society owes its officers the benefit of the doubt (Cobbina, 2016). While we fail to personally charge officers with murder for these extra- 
legal executions, cities are quick to accept civil liability for police killings. Over the span of four years, ten American cities alone were responsible for paying out one billion dollars to settle police misconduct cases, all while refusing to acknowledge or accept any amount of wrongdoing on the part of the police officer (Cobbina, 2016). This is the modern face of being descended from property worth more dead than alive (Sharpe, 2016).

In 2012, the Malcolm X Grassroots Movement (MXGM) published a report called Operation Ghetto Storm that found police, security guards, and vigilantes killed 313 Black people that year; representing one Black person killed every 28 hours in the name of security (Crenshaw, et al., 2015). Despite recent activism against police misconduct and brutality, it was reported that as of August 11, 2021, the police had already killed 657 people (Mapping Police Violence, 2021). Every day in the United States nearly five people are killed in encounters with the police; there have only been nine days in 2021 when the police did not kill anyone (Mapping Police Violence, 2021). The actual figures are likely much higher, but because we are forced to rely solely on news, social media, and grassroots organizations for this information, rather than a central state agency, we are left with huge gaps in our understanding of the pervasive and insidious nature of this problem. The Deaths in Custody Reporting Act (2013) was meant to fill in some of this gap, however, it does not mandate a penalty or governing body to force police departments to comply (Mapping Police Violence, n.d.). Even if departments complied perfectly, it could still take several years for the data to be made public, but police brutality, racial profiling, and over militarization in policing represent core issues of the 21 st century and deserve our immediate attention (Simmons, 2014).

Rates of discrimination in stops, frisks, and arrests are nearly identical between Black men and women, yet "[t]he media's exclusive focus on police violence against Black men" 
makes locating information about the violence against Black women and girls more difficult, erasing us/them "from our demonstrations, our discourse, and our demands to broaden our vision of social justice” (Crenshaw et. al, 2015). Kimberlé Crenshaw and Andrea Ritchie’s Say Her Name report describe Black women and girls as marginalized within the field of Criminology as we/they are in everyday life; rendered invisible in our understanding of police and state violence (Crenshaw et. al, 2015). The startling reality is that since 2015, The Washington Post has identified 250 women that have been killed by the police, with Black women being killed at almost three times the rate of women of other races (Lati, Jenkins \& Brugal, 2020). As the fastest rising demographic in arrests and incarceration, the experiences of Black women and the police need to be seen and examined. This thesis aims to make more visible the violence we silently endure from the police, the media, and society every single day.

\section{Description and Purpose of Study}

Just about every person of color in this country can point to at least one moment when the world stood still, an event that marks the boundary of before and after, after innocence and into knowing. Knowing that as a racially marked being in this world we will never be fully safe, free, or worthy of a "positive peace" that requires the presence of justice (King Jr., 1963). No matter how perfect your command of the English language, your job, income, and education, your religiosity or your cooperation with authorities; you are Black and Brown and a threat to whiteness before you are any of these caveats of white respectability politics, we were raised to believe would protect us from the harm of white fear and anger. As current events show us, these facets of identity do not come into play until after the trigger has been pulled, after the irreversible and the inexcusable has happened. 
For me there are two moments that informed the urgency from which I arrived at a need to undertake this field of study and this project:

The first was 2013, when Trayvon Martin's murderer was found innocent by a jury. Now years later, he is a minor celebrity among racists, selling autographed packages of Skittles (Carey, 2019); the object he claimed was a gun making him fear for his life, justifying the killing of a Black child (Brice-Saddler \& Mettler, 2019). I then understood that the constitutional declaration of liberty and justice for all was at best illusory and at worst mockery in the face of atrocity. The second moment came last summer when we were repeatedly confronted with footage of George Floyd's final moments, his pleas for his life and with the whole world on lockdown, those already restless from being stuck at home had no other distractions and were forced to pay attention to what we had become as a nation, as a people (Cheung, 2020). Resultantly, the attention brought to the circumstances and system that led to George Floyd's death brought forward the narratively hidden death, also due to police violence, of Breonna Taylor months earlier (De la Cretaz, 2020). When we initially learned of Breonna Taylor, the story stood that she was an EMT shot and killed in bed while she slept. The impetus seeming, the story of her death was twisted to make her a more sympathetic victim, one completely innocent; a martyr, to help supercharge the anger George Floyd's death incited within us about police violence (Glover, et al., 2020).

Breonna's story underscores the intricacies of how anti-Blackness combined with misogyny work together to block the wheels of justice. Her story and its continued presence in the media are also important sites of inquiry to examine how and why her death had visibility in a way that all previous Black women victims of police violence never received (Hill, 2020). This thesis came together as I pondered why Breonna Taylor's life and death only seemed to find 
meaning and arouse societal concern in the wake of George Floyd's death. Prior to the public nature of George Floyd's death re-awakening a societal examination and discussion of police brutality, Taylor's death at the hands of police was framed under the lens of its resultant investigation: that of the attempted murder of a police officer and not how the structures and systems of policing failed to protect an innocent woman from being killed in her own home (The New York Times, 2021; Williams, et al., 2020; Mattingly \& Wise, 2020; Glover, et al., 2020). As time went on and the details of Breonna Taylor's life and death unfolded in the media, I saw that I was not George Floyd, I was Breonna Taylor; Black, femme, an EMT and essential healthcare worker during this pandemic, what separates what happened to her and what did not happen to me is luck. Here I stand a healthcare worker, a graduate student, an academic and as the literature will show you in the next chapter none of these things mean anything to ensure my safety because I am Black, and because I am also a woman it probably would not be newsworthy. Black women like me get killed, raped, and abused, we go missing and no one talks about it because no one knows to be concerned; the mainstream media disregards our lives every day.

Why do we say the name Breonna Taylor when we did not say the names of the nearly 250 other Black women who were also killed by the police since 2015 ? While we say the name Breonna Taylor now, it is unclear why we do so, what did it take for us to say her name? In broadly exploring the narrative afterlives of Breonna Taylor that existed in the media in the year following her murder, this study seeks to uncover "what happens when a name becomes the only thing people are saying?" (Romano, 2020). The story of Breonna Taylor "struck a particular chord with the public. In the past year since her death, Taylor's image has been revered, warped, and put back together-again" (Retta, 2021). 
This thesis aims at embodying Black feminism as a theoretical framework and analytic as well as a pedagogical change. Here I re-examine the U.S. issue of police violence and institutional anti-Blackness from the perspective of Black women victims. In so doing, I also adopt contemporary Black feminist pedagogy to performatively counter and disrupt "the violence of abstraction" (Sharpe, 2016; 8; Hartman, 2008; Mignolo, 2009, 2011). Like Saidiya Hartman (2008), Christina Sharpe (2016), Tiffany Lethabo King (2018), and Andrea Ritchie (2018) before me, I write in the first person to use the personal as a window through which the modern color and gender redacted forces of historical and social processes of anti-Blackness can be explored (Alexander, 2012; Ritchie, 2018). This study uses a media content analysis to understand the ways Breonna Taylor's story has been used and misused in the media, for what reason and what effect? What factors predicate the staying power of a Black woman victim of police violence within our consciousness?

Using Breonna Taylor as a case study, I will look at the media coverage of the one-year period following her death, March 13, 2020-March 13, 2021. Following a search of "Breonna Taylor" on NexisUni, a sample of 206 English language news articles was randomly selected and coded by type of narrative frame most often used to discuss her case. This study then, aims to uncover what kinds of stories or facts about her the media most often fixates on in the hopes of unpacking why we have continued to say her name for as longs as we have.

The case studies I bring forth are not isolated events perpetrated by bad apples who require our understanding. They are predictable, historic reproductions of a violence formed of a central thread; the exploitation of our planet's resources through the dispossession and genocide of individuals marked as other. For the offense of ancestral geography; barrier to the possibility of the expansion of European wealth and empire. 
While by no means exhaustive, this study highlights and brings voice, and memorialization to victims of state-sanctioned violence, those we know by name, those we do not, and those who as of the present have yet to fall victim to this violence without end, and are no less important in defining our histories, our present, and our futures.

This thesis is dedicated also in part to those who chose the sea, those who endured, fought, and resisted, who won and who lost. 


\section{CHAPTER II: LITERATURE REVIEW}

"What happens when instead of becoming enraged and shocked every time a Black person is killed in the United States, we recognize Black death as a predictable and constitutive aspect of this democracy? What will happen then if instead of demanding justice we recognize (or at least consider) that the very notion of justice...produces and requires Black exclusion and death as normative?"

-Joy James \& João Costa Vargas, 2012; 193.

Nearly a decade before the summer of 2020 led a global movement towards examining systemic racism through the lens of George Floyd's life and death (Washington Post Staff, 2020), came the 2011 vigilante murder of Trayvon Martin which for many of us is the story of our emerging consciousness to anti-Blackness in policing and justice. Joy James and João Costa Vargas (2012) ask us to think about Trayvon Martin's death as more than just a "tragedy or a media controversy but as a political marker of possibilities;" it is an artifact that allows us to finally come to awareness of the foundational truths this country and its justice system relies on (193). His death and the lack of justice for it, is indicative of the lack of Black social standing and life that began on the slave ship (Sharpe, 2016; Alexander, 2012; Anderson, 2017).

Last summer's Black Lives Matter activism was meant to notify the state that Black men and boys cannot keep getting murdered with impunity (Crenshaw, et al., 2015). It was a desperate plea to the state that largely fell on deaf ears as we continue to see this history unfold almost poetically, as ten miles away, on the day of the verdict in the George Floyd murder trial 20-year-old Daunte Wright was shot and killed by the police because he too was scary (Sharpe, 2016; The New York Times, 2021). The Black Lives Matter movement was responsible for showing us that police killings of Black persons are not aberrant but rather are normative, 
however largely missing from these frames, our activism, and academic study are the Black women victims of state and police violence (James \& Costa Vargas, 2012; Crenshaw, et al., 2015; Hill, 2020). Our comparative silence around the killings of Black women, girls and femmes has the optics of saying these deaths are "acceptable and do not merit repercussions" (Crenshaw, et al., 2015; 6). This thesis uses Breonna Taylor as a case study in order to explicate and explore the diminished social and legal standing Black women occupy in this country. This chapter seeks to chronical a brief history of the racial and gendered politics that have brought us to our present moment in racial (in)justice as well as to define the terms of our present, the final chapters outline how I imagine we can begin to move past these legacies.

In order to aid us in understanding the legal and historic frameworks that led us here, this chapter seeks first to extend the framework and rationale for the study that will guide us through a gender-inclusive reimagining of the New Jim Crow metaphor of mass incarceration first offered by Alexander (2012). This heightened understanding of mass incarceration as a mode of capitalist expansion functions as a basis for the explication of the processes and incentives that brought the state to Breonna Taylor's door and allowed the police to kill her with impunity. Next, I offer speculative pedagogical methodologies to counter the mentioned modes of police misconduct as state violence before delving into their critical implications and how they inconspicuously present themselves in the everyday. Finally, I end with a discussion of the consequences of repressive state violence against Black women.

\section{*Knowing While Black}

Mbembe (2017) argues, there exists no place for Black persons in America to legitimately articulate being vulnerable to systems and structures of white ${ }^{3}$ dominance. Being

\footnotetext{
${ }^{3}$ Here I use "white" in the lowercase with deliberateness because as Reni Eddo-Lodge (2017, x) argues white people never have to be conscious of what it means to be white in the same way a Black person understands
} 
Black or Brown is a life of "self-censorship" where "[your] options are: speak your truth and face the reprisal or bite your tongue and get ahead in life" (Eddo-Lodge, 2017; xii). To be Black or Brown and expose our humanity, to show frustration and anger in the face of someone's blatant refusal to recognize your humanity and attempt to understand your perspective, is to reinscribe within the white imaginary stereotypical Blackness. Instead of being perceived as an advocate, a source of knowing, we are re-framed, re-imagined as a bully, as a threat to their personal safety; nothing we say holds any persuasive power. The only method of enacting change available to people of color is disruption, active resistance. I offer the personal here, in continuation of the legacies and works of the Black feminist scholars that have come before me, to ground myself in this study and disrupt the normative academic research methods that draft us "into the service of a larger destructive force" (Saunders, 2008; 67) by doing violence to our "capacities to read, think and imagine," conditioning us to think through frameworks that "reinscribe our own annihilation" (Sharpe, 2016; 13).

To borrow the words of Christina Sharpe (2016), "every thought I have and speak is Black thought" (5), additionally, I experience my Blackness as a woman. I include the self here to underscore my personhood and experience as being inextricable to any knowledge I produce, what Tiffany Lethabo King (2018) would refer to as being in possession of a "dialect of conquest" (20) or speaking from the experience of a body occupied by the state (Fanon, 1963). This allows me "to tell a story capable of engaging and countering the violence of abstraction" (Hartman, 2008), it is but a single account "of what it means to forge life on landscapes meant to kill you" (King, 2018; xviii). We are said to be in need of a methodology for "encountering a past that is not yet past" (Sharpe, 2016) that allows us to gather and track the phenomena that

their Blackness; it is not visceral. Here I use "white" as interchangeable with "mainstream society," and European American. See also note 1 on "Black." 
overwhelmingly affect Black women. I offer here through this thesis a Black feminist rooted decolonizing discursive and pedagogical change to Criminology research that aims to make police reform more accessible to its Black femme ${ }^{4}$ victims and advocates. Because " $[\mathrm{t}] \mathrm{he}$ journey towards understanding structural racism still requires people of color to prioritize white feelings" $(2017, \mathrm{x})$, it is unproductive to begin dialogue from within this majority-white space about the dynamics of racism and repressive state violence by simply calling the police a white supremacist institution. Instead, I offer a framework, a differential vantage point, from which I guide us to reconceptualize and reimagine what it means to be policed and experience justice in this country as a racially marked being through the operationalization of decolonial theory as a pedagogical change.

\section{Decolonization: Towards the Radical Re-Imagining of the Victim/Offender Relation}

In 2021, it is no longer tenable to simply look at surface-level issues, it is imperative that we now interrogate the root cause arguments. We are at a unique moment in history where we have the consciousness to be able to talk about the ways colonialism still pervades everyday life for the marginalized. In order to unpack this, we must turn to decolonial theory. Decolonial theory posits that Black and Brown life is marked by suffocation by white projects of advancement and wealth generation (Mignolo, 2009, 2011; Valencia, 2018). It is praxis and active resistance to colonial designs.

\section{A Brief History of Decolonial Ideas}

Over the decades, scholars have posited multiple different cosmologies of the term and field of decolonization most notably it has been used to discuss revolution and colonized nations' aspirations for freedom. Decolonization as a verb emerged first within the context of Africa, and

\footnotetext{
${ }^{4}$ I use femme here to be inclusive of any female identifying or coded person.
} 
then the Caribbean when nations attempted to overthrow their European colonizers (Mignolo, 2009, 2011; Gazitambe-Fernández, 2014; O’Dowd \& Heckenberg, 2020). In the 1990s Patrick Wolf said in reference to colonization that "invasion is a structure not an event" (O'Dowd \& Heckenberg, 2020). Fanon (1963) says it is the land and its population colonization comes to occupy, and decolonization needs to originate not on the level of the land but rather within life itself (Clare, 2013). Colonization is so much more than just physical it is cultural and psychological also, it determines whose knowledge and ways of knowing are privileged and respected (O’Dowd \& Heckenberg, 2020; Mignolo, 2011).

Contemporarily, Tuck and Yang's influential 2012 article: "Decolonization is Not a Metaphor" counters this in saying decolonization is nothing more than the repatriation of Indigenous land. Using decolonization or decolonizing methods reduces the field to a metaphor, they posit that this is harmful to Indigenous life and aspirations for self-determination and autonomy. Garba and Sorrentino (2020) follow up this article with the academic equivalent of a diss track: "Slavery is a Metaphor: A Critical Commentary on Eve Tuck and K. Wayne Yang's Decolonization Is Not a Metaphor," positioning us through this to see anti-Blackness as colonization's a priori issue. They state that the ontological violence of the state has overtime sanitized and eroded the visceral imagery and legacy of slavery to the point where it has become lore, slavery is rhetorically reduced then to a metaphor. While Tuck and Yang (2012) concede that fundamental to violence under colonialism is the "triad structure of settler-native-slave," (1) their usage of rhetoric like "humans turned workers" (4) or those brought here due to "coerced immigration...from other colonial contexts" (7) pedagogically erases the slave from the triad through passive articulation of the slave as a "proto-settler" (Garba \& Sorrentino, 2020; 2). These are forms of "semantic displacement" (Garba \& Sorrentino, 2020; 11), "circumlocations" 
(Baptist, 2014; 11), or in Tuck and Yang's (2012) own words “a move to innocence” (17), representative of ontological/epistemic violence (Sharpe, 2016).

The slave is rendered as an abstraction through this kind of discourse in order to undermine the legacy of slavery and the uncomfortable truths of what Indigenous life and power looked like during slavery (Garba \& Sorrentino, 2020). During the Civil War, Indigenous slave owners fought on the side of the Confederacy, some tribes seceded from the union because they too felt compelled to preserve the system of enslavement and anti-Blackness that benefitted them as well (Abel, 1915). The descendants of Black people once enslaved by native tribes to this day are fighting for recognition, fighting for tribal citizenship (Healy, 2020), much in the same way Black persons within the wider context of the United States are fighting for an active and equal political voice and rights (Tighe, 2020). This occupies the same level of colonial violence as Jim Crow legislation, freedmen and their descendants are second-class citizens within tribes as well (Kelly \& Eltohamy, 2021).

Decolonization here, as a verb, functions as a means of subverting these falsified narratives about how the status quo works and how it came to be this way. Tuck and Yang's concept of decolonization then, robs it of action, it ceases to be indicative of active resistance, turning it into nothing more than an empty monument for progress lacking a mechanism for action (Sharpe, 2016). The right to rebel should be recognized as a fundamental human right, without the recognition by the state of the right to register dissent "society will remain a slave to the state" (Oriola, 2005; 105). This project contributes to the literature of decolonization by highlighting and extending the work of Garba and Sorrentino (2020) in underscoring that even in fields of study dedicated to social equality exists anti-Blackness whether it is conscious or not. Central to this thesis is the goal of equipping us with an increased "capacity to notice" and call 
out instances of codified anti-Blackness, this is the operationalization of my decolonized dialectic (King, 2018; 30).

\section{The Decolonized Dialectic}

Historian Edward Baptist (2014) shows us that beginning with the very inception of this nation, our framers and legislators have actively been in the commission of deceiving us. Slavery existed in an explicit, violent, and demeaning way but the state and its institutions were never forced to address it until after the Civil War and the Civil Rights amendments. The first time slavery is explicitly mentioned in the Constitution is in the 13th amendment that formally abolished it. Prior to this the words "slave" and "slavery" were never used, instead, it referred to those trapped into the institution of enslavement as a "person held to service or labor" (Baptist, 2014; 11). It relied on "circumlocations" to dis/re-place the capitalist necessitated white supremacist violence with more benevolent imagery in order to assuage the guilt of the very great framers, ashamed — though not enough to overlook its limitless profits—of the optics of slavery; it was the first of many rhetorical compromises (Baptist, 2014; 11).

While white indentured servants who chose to come to America for a better life, and the slaves formerly known as human, trafficked from Africa, both definitionally served and provided labor for the white elite, their experiences were unequal. The abstract language the state used allows a casual observer or denialist to miss the nuance and difference in experience within this powered system of the two different forms of laborers. This tactic to sidestep acknowledgment still carries ontological violence today when white people decry, they have no privilege; their Irish ancestors were enslaved too as indentured servants. What they neglect to grasp because of the erasure of the horrific nature of Black bondage for labor is the distinction between willful immigration and human trafficking; choice versus force. Terminable and ongoing still (Sharpe, 
2016). This ongoing colonial project is allowed to possess an "edgeless" violence because its terms and methods were never required to be made explicitly clear to us (King, 2018). The legacies of these types of legislation and rhetorical practices in law remain a visceral and devastating facet of Black contemporary life. They continue to give comfort to white America by enabling the belief that Black and Brown persons are deserving of the brutality and violence faced every day (Wang, 2018). Thus, using a phenomenological research method is most appropriate here to allow us to unpack the ways that "slavery and genocide linger in places we do not expect and cannot yet see or define" (King, 2018; x).

George Ciccariello-Maher says in his book Decolonizing Dialectics (2017), that we cannot continue to overlook the relationship between rhetoric, discourse, and colonization. What we need is to engage in a dialectical movement that locates, interrogates, and ultimately removes the harmful colonial frameworks that politely deprioritizes the voices and experiences of marginalized people (Ciccariello-Maher; 2017; 5). Scholars of gender and cultural studies have long advocated for academic writing, specifically scientific writing and discourses, that move away from an omniscient perspective towards one that allows the academic, or the knower, to "reflexively situate and resituate themselves with respect to the objects they are visualizing" (Ochs \& Capps, 1996; 20). Narrative and the self are inextricable. Personal narratives shape how we feel about and respond to events. Language, as a "core element in the epistemological organization of the world" (Valencia, 2018; 25) is extremely powerful as narrative is concurrently born out of and gives shape to those same experiences, it is universal and is one of the first things to emerge in communicative development (Ochs \& Capps, 1996). Thus, the way we talk about things is just as important in shaping reality as what we talk about. We "owe a debt to discourse...[and] its ideas and interpretations about the reality around us," it is no longer 
enough that we look at the shape of policing we must now take the next step towards understanding how that shape took its form through the colonially powered rhetoric and the norms they inspired (Valencia, 2018; 35). We are in need of a pedagogical change in discussing and representing victims and instances of police violence that is able to:

[address] the gratuitous violence that discourses of "settlement" often evade through euphemisms ... The directness of [terms like] "conquest," "genocide," and "murder" short-circuits and avoids the kinds of understatements proffered by theoretical and analytical frames parried by settler colonialism and postcolonial studies. "Conquest," "genocide," and "murder," though seemingly blunt terms, possess expansive lexicons, affects, sensations, and grammars that explicate power, violence, transformation, and shifts over time. The macro, spectacular, and bloody as well as micro, mundane, discursive, and "ephemeral” repertoires of genocide (King, 2018; 45-6).

Explicit stories of Black peoples struggle against the state are rarely depicted in our textbooks, the ones that contend that in the beginning white male colonizers, recoded as missionaries, found Black Africans in trees, living as savage beasts, but through Christ and enslavement they were able to turn those animals into 3/5ths of a man (Sharpe, 2016; Alexander, 2012). This was the first narrative to come out of the social sciences academy, the thought project that engendered criminal justice as an academic discipline and birthed modern policing and its norms rooted in anti-Blackness (Alexander, 2012; Oriola, 2005). These first social scientists conspired with the forces of colonialism to justify the state's crimes against their othered subjects (Oriola, 2005). This foundation of focusing on petty crimes committed by individuals works to conceal the "more atrocious, multidimensional and far more debilitating crimes committed under slavery, colonialism and the ceaseless neocolonialism" by the state and 
the corporations they protect (Oriola, 2005; 105). This is the hidden ontological register of state violence this project aims to further define and explicate to aid in the understanding of the large capacity policing seems to have for violence and misconduct. This reading of the cosmology of Blackness in the diaspora positions us to understand the phenomena of disparate rates of police violence, brutality, and murder against Black and other marginalized persons as aspects of ongoing colonial projects of capture (Sharpe, 2016), through the definitional "expulsion of [B]lackness from humanity itself” (Maynard, 2018; 31).

We need a comprehensive approach to address the police norms that engender the endemic nature of their violence. We are in need of a Criminology methodology capable of formally acknowledging the root causes of our present. This thesis presents a single approach towards engagement in a Black feminist decolonial Criminology.

\section{A Decolonial Criminology}

Criminology as it stands now, functions primarily as a tool of settler colonial domination, it operates in society as a technology of repression along with the police, prisons, and military who surveil, lock us up, and kill us with impunity. The decolonial Criminology I imagine involves an "attempt to counter the denial and normalization of state and corporate crimes, critique the structural and organizational forces that give rise to them, and create political or 'deliberative frames'...that can orient debate and/or produce progressive political action on these issues" (Kramer, 2016; 521). This paper brings us to re-examine the unrecognized blame-worthy harms of the state in the form of excessive police violence (Kramer, 2016). State harm here is defined by three characteristics: 1.) harm has been done to society as a result; 2.) the action in question is condemned by the public; and 3.) it is sanctioned by the state (Kramer, 2016). Police brutality then, falls definitionally into the realm of state crime as, 1.) unnecessary extra-legal 
summary executions occur regularly; 2.) mass international protests condemning U.S. police violence have occurred as a direct response; and 3.) it is endorsed by the state in giving police officers almost un-yielding protection under qualified immunity. In addition to immunity, the cities quick acceptance of civil liability on behalf of their enforcement agents for police beatings and killings through multi-million-dollar settlements to victim's families also points to its internalization (Cobbina, 2018). This is engagement in Kramer's (2016) "prophetic voice". This thesis is a project of public criminology and activism whereby I, in the capacity of a criminologist, attempt to work "directly with specific groups, organizations, social movements or state officials, engaging in dialogue or a process of mutual education that may or may not lead to specific political actions or policies related to the prevention or control of state crime" (521).

Much of the extant Criminology literature is focused on physical manifestations of violence, killings, and death. This study is concerned not with why or how police killings happen but rather is instead premised on police violence as an episteme. It is concerned with uncovering epistemic/ontological and structural violence through linguistic practices. Structural violence is defined here as social inequalities and hierarchies that are inscribed along lines of social categorization like class, race, gender, and sexuality (Holmes, 2013). Symbolic violence is epistemic violence against the self, it is the internalization of forms of structural violence through the unconscious consent of those being dominated by the power structures (Holmes, 2013; Sharpe, 2016). Everyday violence, to the uninitiated eye, is even more insidious and harder to mitigate. Holmes (2013) understands it to be the "bureaucratic dysfunction" of institutions like health care, education, and policing that while generally well-meaning, alienate and otherwise inflict harm on marginalized people by failing to address the different needs of those of other races, genders and economic status (109). These forms of violence produce, conceal, and 
legitimize each other (Holmes, 2013), so it is imperative to include them in our analysis of police misconduct.

Agozino (2003) argues that the projects and technologies of democracy, and law and order like the police are forms of "organized violence" as they have always been marked by “'executive lawlessness' perpetrated with impunity," that rely on the domination of racialized and gendered subjects (Oriola, 2005). Because of this, misconduct and brutality have always characterized policing (Olito, 2020). Ritchie (2017) takes this a step further in saying using terminology like "police brutality" is "meaningless, as violence is inherent to policing" (xv). Early police departments were ruled by politicians who were charged with the appointment of police captains and sergeants, which allowed the elite to use the police to harass and intimidate political opponents. This also meant that payoffs to overlook crimes were very common (Olito, 2020).

The 1929 Wickersham Commission sought to make policing more effective and less corrupt. The resultant reforms that included re-drawing the maps of police districts to no longer overlap with political wards in an effort to increase police professionalism, did not improve institutional legitimacy. As historian Samuel Walker (1983) shows us, these instead engendered police department norms that made them "look-inwards" and "isolate [themselves] from the public." However, accountability from the police requires departments "be answerable to the communities that they are designed to protect and serve" (Cobbina, 2018; 55). What we know as the "thin blue line", emerged as a failed ontological reform effort against police misconduct, that today conceals and normalizes their indiscretions under a code of silence. This study aims to better understand this ontological level of police violence and misconduct that replaced the old blatant forms of the past. To understand and reform the present, we must rupture the false 
narratives of the past that minimize the role state violence against Black communities plays in the maintenance of the status quo. In short, this thesis offers a philosophical investigation into the discursive practices of policing that work to conceal and legitimate the deaths of Black women.

\section{Black Feminism as Inquiry}

Mainstream (white) feminist scholarship mostly depicts the experiences of white women, portraying it as "normative;" the experiences of all other women become subsumed and thus erased by those narratives (Jacobs, 2017; 40). For decades, the race-inclusive feminist literature base concerning violence against women has falsely conflated the experiences of Black, Asian, Latinx, and Indigenous women under the banner of "women of color" (Jacobs, 2017; 40). This "masks the complexity of violence in each community" as "Black women have a very specific history with the state and law enforcement that is not replicated among other women's communities...the relationship between Black women and the state was birthed in violence through the establishment of slavery in the colonial world (Jacobs, 2017; 41). Since the first enslaved arrived on these shores, "Black woman" as a social identity has been an "epistemically disadvantaged" one (Dotson, 2011; 243). Disadvantaged due to the dependency a speaker has on an audience to recognize them as a knower (Dotson, 2011). Previous works of women of color refer to this as a "testimonial oppression," as Black women, systemically undervalued as knowers because society, our audience, is unable to see beyond the pervasive stereotypical imagery of Black women. This has the function of making the unfair treatment of Black women appear as "natural, normal, and inevitable parts of everyday life" (Collins, 2000). The stereotypical imagery of Black women leads to what Brittany Cooper (2018) articulates as "grow[ing] up in a world that only secondarily acknowledges our girlhood and our womanhood. 
We grow up being denied the protections of femininity that are always afforded to white women. And because anti-Blackness is so palpable, it's easy if you aren't paying attention to miss the very sexist ways that racism can present itself' (172). For the purposes of this study then, it is imperative that we examine and discuss state violence from the perspective of Black women.

"The Black woman had to endure the hypocrisies of oppression due to race and gender. She and White women carried many of the same burdens. However, an African heritage lay atop those gender burdens, the oppression of forced labor, physical abuse, and lack of legal recourse or protections" (Browne-Marshall, 2021; 30). So much so self-defense was once illegal for Black women, both from physical harm and in a court of law. It was illegal even "for her father, son or husband" to protect her (Browne-Marshall, 2021; 29). "She could not testify in a case involving White people" even if it meant the murderer of a prominent white man, George Wythe, a mentor to two of the founding fathers, would walk free without it (Browne-Marshall, 2021; 29). I mention this to underscore the depth to which Black women have always been excluded from the U.S. legal system and civic participation. This historic exclusion renders Black women and girls invisible in our conceptions of state and police violence. Because of this invisibility, it is assumed that they/we are shielded from this violence (Crenshaw, et al., 2015; Ritchie, 2017; Jacobs, 2017). The reality is the police kill more than just Black men. Since 2015, 250 women have been killed by the police, with Black women being killed at almost 3 times the rate of women of other races (Lati, Jenkins \& Brugal, 2020).

Kathrine McKittrick (2006) offers Black feminism as an important site of inquiry in order to create a more viable democracy. In engaging in a Black feminist framework, we disengage from the harmful normative patriarchal analyses of the past. Harmful in that they are only capable of producing work and knowledge with only partial explanatory power and because we 
live in a state ruled by heteropatriarchy this partial image of the realities of police misconduct and brutality as state violence is treated as neutral, as encompassing of experiences with police violence and extrajudicial killings (Hill, 2020). A Black feminist rooted decolonial approach asks the question of how Blackness and femininity, within specific historic and present contexts, uniquely collide to specifically engender a type of repressive state violence we have been conditioned to overlook. Requiring that we consider a Criminology that studies Black women not as stereotypic aggressors but as (in/un)visible victims of state violence (Jacobs, 2017; Ritchie, 2017; Oriola, 2005).

It is beyond the scope of this study to offer a quantitative way to measure state violence and repression against Black women or the efficacy of a Black feminist critique. Instead, it offers a theoretical approach to uncover the discursive practices of the state that overwhelmingly disadvantage Black women. This thesis brings forth a potential methodology that could allow for future studies and activism to utilize to better track police violence against Black women. Here it functions as a decolonial option, my praxis for resistance in order to produce work "at the border between hegemonic and dominant forms of knowledge... using the system but doing something else" (Mignolo, 2009; 6-7). It is the embodiment and performance of Black feminism as a disruption of the concealment and erasure of our experiences with the state. My Black feminist framework functions as a means to bring attention and analysis to the discursive patterns used by the state that subtly connect anti-Blackness and misogyny and how this is adopted by the media (Cooper, 2018; 172). This pedagogy is "an expansive analytic of disruption and becoming" (King, 2018; 25) that allows the ability to develop the "awareness and capacity to notice" institutional patterns of erasure of Black women killed by the police (King, 2018; 30). 
Say Her Name. On the growing list of Black people killed by the police we know by name, only two women stand out: Sandra Bland in 2015 and Breonna Taylor in 2020. There was not a five-year moratorium on the killing of Black women. Black women being killed by the police is not an aberration, despite popular discourses and narratives, it is equally as normative to the U.S. social order as the killings of Black men. Since starting to track police killings of women in 2015 The Washington Post has noted 247 women killed, 89 of them were killed at home like Breonna Taylor, 12 of these women were shot while officers were in the commission of a search or arrest. Forty-eight were Black and of those seven were unarmed. Twenty of the 247 women were said to have been killed as "collateral damage," with the police claiming 12 of those times, "the women killed were caught in crossfire or shot accidentally" (Lati, Jenkins \& Brugal, 2020).

The Say Her Name campaign illuminates Black women's unique experiences with police violence in order to un-redact gender and sexuality from racial justice efforts so that All Black Lives can matter equally (Crenshaw, et al., 2015; Hill, 2020). It is a critique and also pedagogical rupture of the prioritization and fixation of Black Lives Matter with Black cis-gendered heterosexual men as victims of police violence (Crenshaw, et al., 2015; Hill, 2020). The report shows us what it means when Black women's struggles with the state continue to be rendered invisible, saying that:

Families who lose Black women to police violence are not regularly invited to speak at rallies and do not receive the same level of community support or media and political attention as families who lose Black men. This leaves the families of Black women killed by the police not only to suffer the loss of their loved ones but also to confront the fact that no one seems to care. Yet the killings of Black women and girls are no less troubling 
than the killings of their male counterparts. Their families mourn no less for their lost loved ones, and they should not be left to suffer in solitude and silence (Crenshaw, et al., 2015).

Andrea Ritchie (2017) asks us to consider how vast a problem repressive state violence would look like if we recognize that along with racial control, gender, sexuality, disability, and nation are also under attack. It is impossible, she says, to challenge in order to eradicate racist violence without also the interrogation and transformation of the social and political contexts that produced it. We have no emergent narratives or dialogues about how femmes are profiled by the police because of their race and sex. We lack the consciousness that after the heavily covered excessive force, sexual abuse and assault are the next most reported form of police misconduct (Bennet, 2018).

Marc Lamont Hill (2020) states that while "Black women have fought to free all of us, we have continued to fight for a world that prioritizes the lives of cisgendered heterosexual Black men" (87). There has been no point in our history of activism where we have "been able to find inspiration for collective resistance in the harmed body of a Black woman, girl, or femme" (Hill, 2020; 90). The deaths of Black men by the police cannot be ignored, but it can also no longer be the only story of police and state violence and brutality that we tell, that registers in our consciousness as wrong. Centering the experiences of Black women within the context of state crime, violence, and misconduct is engagement in my decolonial Criminology. The rest of this chapter aims to illustrate the triad structure of relations that supports the anti-Blackness and misogyny of police violence through the speculative meeting place between colonialism, capitalism, and heteropatriarchy known as "gore capitalism" (Valencia, 2018). 


\section{Gore Capitalism: The Aesthetic and Discursive Practices of State Anti-Blackness}

Gore capitalism, coined by Sayak Valencia (2018), emerges as a critique and conceptualization of the world, it states that the world we live in is marked by "ultraviolent forms of capital accumulation" (20). She theorizes that this be the preeminent model for analyzing Black reality. The point of violence in a gore capitalist society is the destruction of the human body as a service and as a commodity as "death has become the most profitable business in existence" (Valencia, 2018; 20). The white elite are said to be monetarily empowered through the direct and indirect support of Black death through slavery and segregation in what is known as "necroempowerment" (Valencia, 2018; 20). Reading our present moment in racial justice through gore capitalism allows us to understand the role of police violence as a function of state projects of advancement and settlement as our police are said to be "violence specialists" hired by the state (Valencia, 2018; 65) to preserve the capitalist world order. Fanon (1963) allows us to explicate this further in saying that the police and military are the "spokesman of the settler and his rule of oppression" these "agents of the government speak the language of pure force...with the clear conscience of an upholder of the peace; yet he is the bringer of violence into the home and into the mind of the native" (Fanon, 1963; 38). The U.S. government developed a police force "that views the public not as a customer or body to protect but an entity that is hostile" the streets here are viewed as no different as those of a warzone (Murray, 2016; para. 5). Valencia (2018) equates police officers, soldiers, and guards with gangs and thugs as their collective usage of "violence as an everyday, guilt-free practice means that this extra-state sovereignty complicates the relation between violence and the economy" (90).

This conceptualization of the world allows us to understand the role of police violence as a function of state projects of advancement and settlement. Understanding our world in terms of 
gore capitalism also allows us the tools to move past "hegemonic femin[ist]" critiques of violence by prioritizing self-reflexivity and interrogating the inextricable role gender and race play in capitalism and colonialism (Valencia, 2018). Gore capitalism allows us to more completely frame the Black present, as a contemporary history based on the "vast numbers of the dead" rather than "the experiences of survivors" (Valencia, 2018; 28). Through the processes of gore capitalism Blackness is framed around death and dying; it is a project of mourning (Sharpe, 2016; Valencia, 2018).

\section{Decolonizing the Past}

The first Black Africans brought to the United States in 1619 were twice stolen. First by the Portuguese from their indigenous lands in Angola, and again by English pirates in the Gulf of Mexico on route to Veracruz's slave auctions. These first enslaved people faced yet another long journey to get to the colonies, chained to the walls and each other "covered in vomit, menses, and feces" (Browne-Marshall, 2021; 5). I mention the minutia here to underscore the magnitude and layers of violation and dispossession faced by Black persons in this country, I mention this to make explicit that Black subjugation and bondage is built into the framework of this land and economic system. Nearly a year before the great American origin story arrived with The Mayflower, before even democracy, existed the chattel slave (Browne-Marshall, 2021).

Ours is a history marred by greed, accumulation, and dispossession, from our homes, humanity, bodily autonomy, and our capacities to be and to think (McKittrick, 2006; King, 2018). There is no single era, presidential administration, or policy that has brought us to the present moment, this is the ground we have always tread in regard to race, the distinction now being we have a new lens, consciousness, from which to view this violence in Critical Race Theory (CRT) (Crenshaw, 1988; Ladson-Billings, 1998). Anti-Blackness as a legal doctrine 
began on the shores of what is now Senegal in 1441 when Portuguese sailors in search of gold returned home instead with Black human cargo and an idea for a new exploitative form of economy in chattel slavery (Browne-Marshall, 2021).

The history books like to pretend legalized racism and discrimination in the United States ended with the abolishment of slavery in 1865 but this could not be further from the truth. The conclusion of the Civil War brought an in-name only end to the official and explicit system of enslavement and "200 years of law normalizing violence towards Black men and women" (Jacobs, 2017; 45). This self-professed Christian nation made necessary the need to justify the normative rape, mutilation, and murder of Black women and men on the plantations during slavery (Jacobs, 2017). To accomplish this, the state and elites relied on dehumanization through stereotypes, Black men were coded as violent animals and Black women were wild sexual creatures lacking morality in need of being tamed (Jacobs, 2017).

\section{Mortgaging Black Bodies: Race, Capital, Policing and White Supremacy}

The first cohort of 20 enslaved Black Africans in the United States were brought to the Jamestown colony, where their skills in agriculture, animal domestication, and metalwork were in great demand as the European settlers struggled to survive in this new hostile environment (Browne-Marshall, 2021). At the time of their arrival, the colony was struggling, by its first summer of settlement half of its people had died of heatstroke, starvation, pneumonia, and attack from displaced Indigenous nations like the Powhatan (Browne-Marshall, 2021). At this same time, the Southern colonies were also dying until cotton became more time effective to harvest and process with the invention of the cotton gin (Baptist, 2014; Alexander, 2012). Cotton, tobacco, and Black bodies would eventually go on to become the benefactors of the Southern states, the cotton/textile industry alone would soon amount to forty-two percent of the entire U.S. 
economy; planting, watering, cultivating, and harvesting crops meant an explosion in demand for land and bodies to work it (Browne-Marshall, 2021; Baptist, 2014; Alexander, 2012). Maintaining this economy necessitated Native genocide and perpetual Black bondage.

The early period of U.S. history was marked by a mass of poor white and Black servants, not yet the chattel slaves as we conceive of them now, occupying the same economic and social class. Both were met with equal disrepute and unprotection from the plantation owners and most importantly, lawmakers (Alexander, 2012; Browne-Marshall, 2021). These poor white and Black persons coexisted peacefully, working side-by-side, even relaxing together when not toiling in the fields until a series of slave revolts threatened the social and economic order set in place by the ruling elite (Alexander, 2012). Bacon's rebellion, 1675, so shocked and terrified the ruling elite when a white man armed and formally united these poor Black and white workers with the goal of overthrowing them. Though this rebellion was eventually snuffed, many like it soon followed and the fear that the tenuous balance that the white ruling class had over everyone else would soon collapse, saw the workforce shift in composition to rely heavily on slave labor rather than cheap paid labor (Alexander, 2012). Native or Indigenous peoples were not suitable to be slaves because they were in a position to fight back, so much so, many would go on to enter the institution of slavery as masters instead through the conquest of white settlers and their property (Alexander, 2012; Baptist, 2014). Poor whites were also not preferred as slaves because it would interfere with U.S. expansion by tempering voluntary immigration from Europe (Alexander, 2012). Importing the slave class from Africa ensured that slaves would be too weak to fight the bonds of slavery and the U.S. economy could continue to flourish for years to come (Alexander, 2012). The racial bribe of white supremacy relied on two things to function: accumulation and dehumanization. 
Psychologist David Livingstone-Smith (2011) remarks that "[i]n dehumanizing others, we exclude them from the circle of moral obligation. We can then kill, oppress, and enslave them with impunity. Taking the life of a dehumanized person becomes of no greater consequence than crushing an insect under one's boot" (para. 8). Slavery facilitated the creation of race in order to justify previously unimaginable acts of violence by removing the personhood from the victim. Instead of feeling shame, derision, and anger at the prospect of slaughtering entire communities solely out of greed, or ripping people from their autonomy, homes, and humanity; white colonial subjects could instead feel good if those subjected to the atrocities of repressive state violence were instead of human, animals. The Black slave, as the first racialized subject was the product of two impulses: the possibility of violence without limits and as a symbol of vulnerability without a safety net (Mbembe, 2017). These Black bodies were encoded as less than human chattel, "natural machines," sites of commodity production, with reduced capacities for pain and death; an unkillable monster (Maynard, 2018; 30).

Slavery is the basis of the economy we are entrenched in today; long before there was a stock market or cryptocurrencies with the potential to explode the wealth of investors overnight, came the buying and selling of Black humans. Black bodies were the first sure thing investment; an insurable property (Sharpe, 2016). Loans, mortgages, credit, and credit history emerged specifically to increase access to the American dream, it made wealth for white people yearning for a new beginning and a better life accessible (Baptist, 2014). Once you owned a slave you could have greater credit extended to you to buy land and the necessary things to plant it. Everyone descended from the initial investment would also be yours to extract labor from or sell for additional profit, they were property that could be inherited, that birthed more property. Land and property ownership, central to wealth building, made the maintenance of race-based slavery 
through segregation and discrimination to the direct benefit of white persons, this is the bribe, the privilege afforded to white skin. White supremacy was created to form the boundary between white and Black; it was a racial bribe to quell the intra-class solidarity that threatened to dismantle their newly thriving systems of control and profit. White servants on the plantation were given elevated status over their equally poor and disenfranchised Black counterparts while white persons off the plantation were given greater access to newly conquered native territories and the ability to police slaves and freed Black men through slave patrols and militias (Alexander, 2012).

The pull yourself up by the bootstraps, rags to riches story of the U.S. began with the dehumanization, torture, buying, and selling of Black humans. Wealth has always been wrapped in the legacy of race and racism, and stereotypes of dispossession (captivity, lost homelands, evictions, joblessness, criminality, and incarceration) Black life then, is translated as being ungeographic, or that which has no place (McKittrick, 2006). Under this framework, all acts committed by Black persons would automatically arouse white suspicion and fear, as Blackness within the context of this land has always been associated with guilt and criminality (Wang, 2018). White fear as anti-Blackness becomes the very framework this nation and its major institutions are built on. It was the fear that ending slavery would crush the economies of the Southern States, and influxes of the wrong kind of immigrant would bring crime, disease, and poverty that necessitated the creation and maintenance of policing (Waxman, 2017; Olito, 2017).

\section{A Mandate to Kill?}

The first charge of policing was to protect white persons and wealth by any means necessary. In the slave-free states of the north, businessmen found they could "save money by transferring the cost to maintain a police force to citizens by arguing that it was for the 
'collective good" encoded as law and order (Waxman, 2017). It was easy to get the public in agreement with this, as the large waves of new immigrants who practiced Catholicism from Ireland and Italy, as well as those hailing from Germany, and Eastern Europe (Waxman, 2017) were said to be ruining society; crime rates rose, among them "mobs, public lewdness, disorderly conduct and prostitution" (Olito, 2017). These first police departments were often also charged with the protection of white property from Native savages, like that of St. Louis. Killing an Indigenous person would not become a crime until well into the $18^{\text {th }}$ century (Ritchie, 2017). As major sources of wealth building and maintenance, it made sense that the dispossession of Black and Indigenous beings through (re)capture and genocide would present the basis of nearly all legal doctrines at the time. The return of runaway slaves is the origin of policing models in the southern states, these departments began with slave patrols and militias of groups of men on horseback carrying whips, guns, and rope, in order to chase and hunt escaped slaves, terrorizing slave communities to suppress riots and even to keep plantation owners in line (Olito, 2020). Killing an escaped slave in the commission of this return process was completely legal, a dead body here meant an insurance payout for the plantation owner; dead or alive the Black body was and is very profitable (Baptist, 2014; Alexander, 2012; Sharpe, 2016). Following the abolishment of slavery these slave patrols transformed, eventually becoming the first police departments and the Ku Klux Klan (Olito, 2020). The average southern police officer was said to be "a promoted poor white with a legal sanction to use a weapon" and "his social heritage taught him to despise the negro" (Myrdal, 1944; 540-1; Chaney \& Robertson, 2013; 483). The impact of this statement being "probably no group of Whites in America have a lower opinion of the Negro people and are more fixed in their views than Southern policeman" (Myrdal, 1944; 540-1; Chaney \& Robertson, 2013; 483). Following the formal end of slavery 
came seven years of Reconstruction which was brought to an abrupt end by unmitigated antiBlack violence, ushering in 100 years of legalized Jim Crow segregation undoing all Black gains (Jacobs, 2017; Anderson, 2017; Alexander, 2012). Scholars contend that Jim Crow segregation continues in the present, but it is now implicit. Black skin was pathologized and slavery reemerged under the logics of "carceral capitalism" (Wang, 2018).

\section{Carceral Capitalism and Mass Incarceration}

Carol Anderson boldly asserts that following Emancipation:

Southern courts transferred full control of black people from the plantation owner to a carceral state. The instrument of re-enslavement was a brutal deployment of sheriffs, judges, and hard labor punishments for black-only offenses such as carrying a firearm, making an insulting gesture, or stealing a pig. African Americans were then swept into the prison system to have their labor fill the coffers of the state and line the pockets of the plantation, mine, and lumber mill owners $(2017,28)$.

Black persons without a job were charged with vagrancy and put back on the auction blocks so that their labor and bodies could once again be sold off to the highest bidder (Anderson, 2017). Being Black and self-sufficient was made illegal, the only legal employment allowed was domestic work, mainly for women and laboring/agricultural jobs for men. These laws even outlawed hunting and fishing, denying Black persons the right to not starve (Anderson, 2017). In short, these Reconstruction Era laws governing Blackness criminalized the very reflex to stay alive and they were the beginning of mass incarceration.

The passage of the 13th amendment marked the first wave of mass incarceration, for while it formally ended slavery, it did so with the addendum forced labor was now only permissible as punishment for a crime (Alexander, 2012), "justice, however...was never on the 
docket" (Anderson, 2017; 28). The 13th amendment is the loophole that allowed the southern states to rebuild following the Civil War, it also provided a means to calm the fears of poor working-class white Americans terrified of increased economic competition from the newly freed slaves. It solidified white solidarity as supremacy (Duvernay \& Moran, 2016). Legislation favors the framer, that is, the primary beneficiary of law and the definition of order it seeks to preserve are the white people who created it (Bell, 2020). Mass incarceration is defined here as a political campaign to quell white fears surrounding Black integration into white middle-class America through the historic and systematic and "moral" recapturing of Black people under the framework of being "tough on crime" by imposing a post-carceral civic death (Alexander, 2012).

Once the economic conditions of the south became untenable and World War I provided the prospect of high wages up north, the Black Codes allowed police to stop the trains headed towards a better life and to arrest those whose only crime was leaving the state (Anderson, 2017). The further gains to the Black community through the Civil Rights Movement brought with it another wave of white resentment—rage — that further undermined the power of Brown, the Voting Rights Act, made higher education less attainable, and brought crack cocaine into the inner cities which led the way for more Black men to be imprisoned than even Apartheid South Africa (Anderson, 2017). The Civil Rights Movement led to a legislative shift to being tough on problems associated with minority communities, once white people saw that the equality promised by the movement would actually require that they make sacrifices. White persons felt aggrieved insisting that Black persons were asking for too much too fast, which in turn allowed politicians an opening to exploit the growing resentments of poor working-class whites (Alexander, 2012). This new political era of appealing to white swing voters is best exemplified by looking at Clinton's legislative contributions to being tough on crime, that are responsible for 
the greatest increase in federal and state prisoners than any other president in U.S. history (Alexander, 2012).

\section{Framing Mass Incarceration as State Anti-Blackness}

In her eye-opening work, The New Jim Crow, civil rights lawyer Michelle Alexander (2012) guides us to acknowledge post-civil rights America as being far from an ideal space for Black and Brown bodies. The everyday violence and violation we experience from the state was just moved off the screen once it became "unfashionable" to be racist, the impulse to dominate Blacks did not change, the racial undertones of legislative intent were hidden; made colorblind through the mass incarceration of Black and Brown bodies (Alexander, 2012). Christina Sharpe (2016) notes mass incarceration as the legitimate face of the "ongoingness of Black capture" in which she takes a step further and extends by describing anti-Blackness as being as pervasive as the weather; it is the climate in which we live (Sharpe, 2017). Sharpe (2016) guides us to consider that the absence of a national museum of slavery is discursive proof via erasure that enslavement in America has not yet met its conclusion. The museum, like the memorial, represents a form of reparation, to spur reconciliation through the acceptance that wrongdoing has occurred. The absence of a national museum of chattel slavery is perhaps a pedagogical concession of sort that slavery continues under new names and frameworks (Sharpe, 2016; 20).

Carol Anderson (2017) frames the present as one rooted in "white rage," the response to Black advancement. It is not just the presence of Black persons that spur the creation of "colorblind" implicitly racist and discriminatory legislation (Alexander, 2012); it is instead born

of the impulse against "[Blackness] with ambition...with demands for full and equal citizenship" (Anderson, 2017; 3). White rage claims a monopoly on morality, it is the mentality that chastises Blackness through narratives of poverty, criminality, and lack of family values (Anderson, 
2017). "This unmoral, unethical anger has the full support of the state. It is the only anger that the state recognizes; the only anger not criminalized or met with deadly brutal force" (Sharpe, 2016; para. 8). The rage born out of white supremacy is something we are told to understand and make room for, when white supremacist Dylan Roof shot and killed nine Black persons at the Emanuel African Methodist Episcopal in South Carolina, officers took him alive and out of sympathy took him to a drive-thru on the way to the police station because he said he was tired and hungry (Sharpe, 2016). Black people of all ages and gender presentations and identities, suspected of far lesser crimes, are rarely "the beneficiary of such restraint" (Jacobs, 2017; 57). White rage is also seen through politicians both Black and white calling on Black persons to just step up and be fathers, as Obama did, to fix their own communities and to stop using the police as scapegoats for issues plaguing Black neighborhoods as opposed to addressing the forces that formed the present (Anderson, 2017; Alexander, 2012).

\section{Carceral Capitalism}

When we first think of policing, often what comes to mind are the charismatic men in blue who work tirelessly to keep our communities safe and solve crimes. If they have to dangle a few people over ledges or shoot them in the foot to get lifesaving information out of suspects so be it. These are among the most readily available images of police use of force in possession by the U.S. American imaginary. Michelle Alexander (2012) equates this programming to old movies like Gone with the Wind that portray "happy slaves" effectually glorifying slavery through its romanticization (Zakaria, 2016), placing a "fictional gloss" over "a brutal system of racialized oppression and control" (Alexander, 2012; 59). This glorification naturalizes state and police violence, allowing the majority of U.S. Americans to never have to confront the notion of police legitimacy because these shows, like the evening news, are told from the perspective of 
law enforcement. What we rarely see is the truth, the predatory policing practices that extend from the plantation, and Jim Crow era to civically exclude persons of color for further white profit and gain (Alexander, 2012; Anderson, 2017).

Jackie Wang (2018) illustrates in Carceral Capitalism that today states and local governments run on an "offender-funded policing and punishment" model that is marked by "the hyper-exploitation of residents by the police" (21). At face value, the U.S. operates on a "fiat currency system" which allows for government spending at immense deficits without the need to raise money as the state assumes a monopoly on the issuance of their currency (Wang, 2018; 15). This is the way federal government spending works but it does not apply to state and local governments who instead must issue bonds and make payments on their debt, or they must find a way to make money because unlike individuals and corporations, state governments cannot declare bankruptcy (Wang, 2018). The government will have you believe that their primary method of earning money is through taxation and bonds, but studies point to a more insidious and predatory mode of budget-balancing that operates through the economics of incarceration. Policing is a for-profit institution, it uses fines and fees to "squeeze money out of [the] people who come into contact with [them]" (Wang, 2018; 21). States "use the police power and court system to loot residents" (Wang, 2018; 22).

\section{The Faces of Carceral Capitalism and Mass Incarceration}

The Drug War. David Simon says in the documentary The House That I Live In, "' $[\mathrm{t}] \mathrm{he}$ drug war is a holocaust in slow motion' It's identifying a group, ghettoising that group, confiscating their rights and concentrating them in prisons, and exploiting them for financial gain" (Clements, 2013). Marijuana, opium, coca, and psychedelics were legal for thousands of years, they were used for medicinal and spiritual/religious purposes (Drug Policy Alliance, 
2020). In the late 1800 s, marijuana was prescribed to treat migraines, rheumatism, and insomnia and cocaine was used to treat sinusitis, hay fever, and chronic fatigue. They were also used recreationally, cocaine was a common ingredient in wines and soda (ACLU, n.d.). Once the white elite began to take issue with the large numbers of people immigrating from China, the first laws limiting the use of opium were made in the 1870s due to the drug's association with this perceived out group. The early 20th century brought forth legislation banning the use of cocaine as it began to be associated with Black people in the south. The 1910s and 1920s saw laws ending the legal use of marijuana in order to target Mexican Americans and Mexican migrant workers (Drug Policy Alliance, 2020). The Harrison Act (1914) banned opiates and cocaine and not long after that came alcohol prohibition (ACLU, n.d.). By the 1960's drugs had become emblematic of youthful rebellion, social upheaval, and political dissent, and a decade later in 1971 then President Nixon announced a "war on drugs." Top Nixon aide John Ehrlichman would later publicly admit the administration had two enemies: anti-war liberals and Black people. They knew it would be impossible to make being Black or anti-war illegal, so they pathologized both groups linking marijuana to anti-war hippies and heroin with Blacks. Both drugs were then heavily criminalized so that their leaders could then be arrested, and their homes raided "night after night on the evening news" in order to vilify them; to disrupt, delegitimize, and silence the political agendas of both groups (Drug Policy Alliance, 2020). Might we understand then, the war on drugs as the face of a war on the poor and non-white; wars on crime are the easiest way to warehouse Black men to disenfranchise and force into perpetual historic bondage and free labor (Oriola, 2005).

When high crime rates are framed as an issue of the Black community as opposed to an issue of the nature of corrections as an instrument of control over Black persons, beginning with 
fugitive slave laws and now as the War on Drugs, the stigma and criticism falls on the person as opposed to the power dynamics and laws that discriminately contribute to oppression (Anderson, 2016; Alexander, 2012). The Drug War is key for exploding the incarceration rate of Black and Brown men and redistributing wealth and resources from historically marginalized communities to white ones (Alexander, 2012). The Drug War allowed a colorblind reason to disinvest in Black communities, mounting felonies meant fewer people qualified for government-subsidized housing, this money was then reallocated to building new prisons to house these new prisoners. These prisons were built in small white rural communities for several reasons 1.) building prisons meant jobs for mostly white construction workers, 2.) once completed, these prisons would be the primary employer of those towns, and 3.) prisoners would count towards the town's population, meaning greater federal funding and most importantly greater political representation (Wang, 2018; Alexander, 2012). As you can see the racial bribe continues well into the present, once again Black bodies ensured greater white political power while exercising very little of our own.

Clinton's Drug War also allowed the police to confiscate all money and possessions they consider to be from drug activity, including cars and homes under Civil Asset Forfeiture (Alexander, 2012). They do not have to provide proof, just reasonable (to them) suspicion of illegal drug activity, and they can seize the property without a warrant, notice, or hearing. Even if the person is innocent, 80 percent of these forfeitures are uncontested because most caught up in this system are poor and Black and Brown without the means to get legal counsel to prove the "innocence" of the property (Alexander, 2012; 79). Once confiscated this property becomes the that of the Police Department that took it. In addition to receiving federal funding for each person arrested under the drug war mandate, police departments were also allowed to keep all 
suspected drug-related property and assets to do with as they pleased, they auction off these cars and homes for profit or they can keep them for whatever purposes they see fit. A Department of Justice report showed that between 1988 and 1992, drug task forces seized over $\$ 1$ billion under this program (Alexander, 2012).

1994 is the most important contemporary date for the explosion of mass incarceration, it saw the implementation of the "three strikes law" and "zero tolerance policies" which will be examined further in the next section under the framework of education (Alexander, 2012). Life sentences became mandatory for those on their third offense, the majority of whom caught under this mandate were Black men arrested for non-violent drug crimes. Clinton is charged also with the creation of the current racial caste system, that greatly increased the extra-legal penalties for drug crimes, taking away the ability for Black persons swept up in Drug War arrests from properly re-integrating into society, by disqualifying them from public assistance in housing, food stamps, and financial aid almost ensuring recidivism will happen (Alexander, 2012).

School to Prison Pipeline. Instead of being a site for learning, development, and safety, the schools are said to function for Black people as a holding cell on the route to greater criminality and prison; they are a front in the war against Black advancement (Anderson, 2017). The carceral pipeline this creates highlights the role of the school as a "microcosm" of our antiBlack society (Bell, 2020). Black students are dehumanized, reduced to a physical or moral threat to whiteness through educational policy that follows a "colorblind" framework that decontextualizes the life experiences of students in order to push them out of schools (Alexander, 2012; Bell, 2020).

Following the Civil War, the formerly enslaved celebrated their victory by working to establish financial independence. Central to this meant pooling what little money was available 
to them to build schools, the newly freed sought high-quality education as a means to "break the generational chains of enforced ignorance and subjugation" of slavery (Anderson, 2017; 7). This forward motion was impeded by military order and Supreme Court decisions that tossed Black persons off the forty acres promised to them as reparation for slavery so they could not create wealth and sustain their communities, and destroying the protections given by the 13th, 14th, and 15th amendments. Brown v. Board of Education (1954) was brought to the Supreme Court because the scholastic achievement differential between Black and white students was so egregious it was called a "critical social problem" (Bell, 2020). At face value the outcome of the court's decision once again gave Black children the opportunity to have a decent education, but many white people saw desegregation and Black children as a threat to the racial hierarchy, beginning the momentum to close public schools to divert funding to private schools. This is a facet of white flight and had the effect of "leaving millions of citizens in educational rot, [whites were] willing even to undermine national security...to ensure that [Blacks] did not advance" (Anderson, 2017; 5).

Bill Clinton's policies draw a direct line from the school-to-prison-pipeline and Black "hyper-incarceration" (Bell, 2020; Alexander, 2012). The Gun Free Schools Act (1994) was an extension of the "tough on crime" stance that led to the "three strikes law," it sought to make schools safer by taking a "zero tolerance" approach to weapons on school grounds (Bell, 2020). The greatest issue with this act was the paradigm shift it caused in school punishment that extended to any acts considered violent. The impetus of the previous statement is the subjective nature of what is coded as violent, the literature shows us that Black life has always relied on resistance, revolt; fighting against the chains we were born into but the framework of innocence in this country fetishizes passivity (Wang, 2018). Under this logic where the color of our skin 
imposes a "discursive and political impasse" Black persons are positioned always as antithetical to innocence (Wang, 2018; 14). Any act meant to counter the status quo and the white imaginary's association of Blackness with guilt and criminality, like achievement and advancement, will always be framed as violence (Anderson, 2017; Ciccariello-Maher, 2016; Wang, 2018).

This assignment of guilt begins at birth, there is no big distinction in rates of arrest, or violence between Black men and boys or women and girls (Crenshaw, et al., 2015). Black skin elicits fear without regard to age, gender, wealth, or education. The historic context shows Black girls are 19 times more likely to be arrested than white girls due to stereotypes of Black female deviance and hypersexuality that lead to Black girls normatively facing suspension for dress code violations (Ritchie, 2017; 30-1). Black girls are more likely to face punishment for insubordination and dress code violations, while Black boys are more likely to be targeted for their physical size and engaging in self-defense. Both demographics, however, share a propensity to be targeted for having natural hairstyles like braids or dreadlocks (Bell, 2020). These infractions share a similar theme — professionalism—which I posit as code for respect, for tradition, and therefore authority. Respect seems to be a recurrent theme when it comes to the justification by police officers and teachers for why violence against Black persons was warranted (Cobbina, 2018; Bell, 2020).

\section{Because He Was Scary_Police Violence Against Black Men}

Early policing was a very informal for-profit institution that relied on volunteers to perform "night watch" in order to look out for people engaging in prostitution and gambling (Waxman, 2017). This system became useless once communities exploded in size, but its legacy remains with us today. It is seen most explicitly in Citizen's Arrest and Stand Your Ground 
Laws; they provided the legislative mandate and call to action that compelled George Zimmerman to murder Trayvon Martin in the name of maintaining law and order. They were also said to have been the impetus for Ahmad Arbery to be pursued to his death like an animal by armed white men claiming they believed him to be a burglary suspect (CBS/AP, 2021). Citizen's Arrest Laws were adopted to facilitate the roundup and return of runaway slaves, and later in the post-Civil War era helped to justify the lynching of Blacks (CBS/AP, 2021). The extant literature on police shootings shows that unarmed Black people are shot by the police at significantly higher rates than armed white people (Weitzer, 2015).

Mass media's portrayal of Black men has been instrumental in shaping the role of Black people in society as super predators/criminals, the more Afrocentric one's facial features are the more likely they are perceived to be socially deviant and violent (Chaney \& Robertson, 2013). These media portrayals do not create stereotypes, they work by activating pre-existing ones. It is infantilizing to say that society is shackled to these ideas presented in the media with no agency in engendering and putting into action these forms of discrimination (Chaney \& Robertson, 2013). We have the ability to challenge these images by reframing and illustrating the root causes and implications of stereotypical Blackness. The repeated images of Black men killed and beaten by the police: Rodney King, Trayvon Martin, Freddie Gray, Michael Brown, Oscar Grant, the predominately minority victims of natural disasters, and now George Floyd, were meant to pose a wakeup call to the country, to provide a call to action (Hill; 2020; Sharpe, 2016; Butler, 2017c). But instead of leading to non-Black spectators picking up the mantle for civil and human rights, it confirms the status, location, and already held notions about Blackness within dominant white ideology. The meanings/ meaningfulness of Black life goes unchanged. The repetition of the visual, discursive cruelty of state violence on Black bodies does not lead to an end of the 
violence, nor does it transform notions of morality and bring sympathy. It numbs consciousness over Black death and suffering over time, it is another form of state violence, it positions Black death as normative and unworthy of moral concern (Sharpe, 2016; James \& Costa Vargas, 2012). It makes continuous the colonial project of violence. These images in the media are antithetical to morality; they are intrinsically unethical as state violence transforms into more than just a tool of repression, it turns "social justice" into "decorative" merchandise in the service of "dystopian empowerment" (Valencia, 2018; 135). Sharing these images and videos on social media is not enough to free us from the bondage of white supremacist violence, we must take it a step further and interrogate them. In order to free us, we must liberate these images from controlling state and police narratives that frame the deaths of Black people as merited and justifiable because these officers genuinely feared for their lives.

\section{Stop and Frisk}

As the preeminent crime control policy of the land, Stop and Frisk has been referred to as the "most visceral manifestation of the state" in the lives of Black men; "threat to democratic values" (Butler, 2017c; 83). It is the brutal deployment of police dominance onto communities of color, expressing to Black men "they are objects of disdain by the state" illustrated through "sexual harassment [which] bleeds into torture. Torture [that] bleeds into terrorism" (Butler, 2017c; 84). Stop and Frisk as a framework allows us to unpack hidden dimensions and connections between racism and sadism. As history illustrates, the abuse of Black men via lynching and police interactions often have a sexual component (Butler, 2017c).

\footnotetext{
${ }^{5}$ I use Black men here in this section not in continuation of the erasure of the experiences of Black women victims of police violence, but in keeping with the norms set forth by the mainstream narratives presented in the media as well as the academic literature that locates these forms of violence as a Black male affliction. I offer it as a stark reminder how prevalent the practice remains. The next section deconstructs, in order to reconstruct, the story of state violence by detailing the way it unfolds onto the bodies of Black women.
} 
While no one has died as a direct result of this search and seizure, the police are permitted to, and often do, use deadly force in the commission of these stops once they determine the suspect is non-compliant and presents a risk to the life of the officer(s) (Butler, 2017a, 2017c).

\section{Can't Breathe: An American Saga}

Demonstrations against police brutality are far from a modern construct, many of the major civil rights flashpoints are centered around instances of police brutality. Suspects claiming not to be able to breathe is a historic reproduction, claims of Black inferiority have been based on lung capacity since the Civil War. The Civil War study, in which the dead bodies of Blacks killed in the war were dissected and studied, led Thomas Jefferson to conclude there was a dysfunction in the lung function of the Black people. This was scientific physiological proof that Black bodies were fundamentally different than white bodies. To him, this signified that Black bodies were fit only for physical labor and toiling in the fields. What was this physiologic flaw? Having a lower lung capacity than whites. Meaning, because white people had evolved to develop a greater lung capacity as they migrated further north where the altitude was higher and the air thinner this somehow made them superior and thus too good for agricultural work (Sharpe, 2016). Slavery based on this logic of inferiority gave purpose to a people with a flawed physiology; it kept Black bodies alive (Sharpe, 2016; Braun \& Shaban, 2014).

In 1982 civil rights advocates became inflamed when LA police chief Daryl Gates very publicly stated: "Blacks are more likely to die from chokeholds because their arteries don't open as fast as arteries do in "normal people"' (Sharpe, 2016; 109). Under this logic, when Black suspects complain about not being able to breathe, the police and state imaginary reframe it as a problem in a flawed human being, not the systematic flaw in aggressive policing. Seven years 
later in 1991, activist Rodney King was almost beaten to death by LA police. This event was a major flashpoint that led to the LA riots, I posit here as analogous to the protests that emerged in the wake of the police killing of George Floyd. The images and sheer brutality of the beating left the public speechless, in shock that he survived 56 vicious strikes. The police used footage of this brutality not to begin conversations of major reform or to take responsibility and mark a move to restorative justice with the Black community, no, it was used to convince the public that the chokehold which had been banned in policing for 20 years was humane in comparison and they should bring it back (Sharpe, 2016). When Eric Garner was killed in 2014, suffocated to death at the hands of police, questions on whether the chokehold was humane were brought back to the surface. He calls out 11 times that he could not breathe. The problem here is that while the NYC medical examiner charged that his death was the result of homicidal asphyxiation, the NYPD said that their officer did not use a chokehold, removing the ability to critique and reform policing practices once more (Sharpe, 2016; 110).

After George Floyd was murdered two autopsies were ordered and completed, one by the state and the other undertaken by a private coroner hired by his family. Both concluded Floyd's death was a result of homicidal violence. The county medical examiner's office said he succumbed to cardiac arrest secondary to law enforcement restraint, the compression of his neck in order to subdue him. However, the state also claimed that Floyd suffered from heart disease and was high on fentanyl at the time of his death (Taylor, 2021). The county ME office admits Chauvin's knee on his neck ultimately killed him but feels the need to also say he was high on opiates and had an underlying heart problem. This has two effects: 1.) paints Floyd as a criminal drug user and 2.) positions us to consider the remote chance his death was the result of his own flawed physiology; a normal human would have been able to survive what was done to him. The 
second autopsy reached a different conclusion supported by his medical history, that he had no underlying medical conditions that could have complicated or contributed to his death (Taylor, 2021). He died from the injuries sustained to his neck; there is no room for reasonable doubt. This is the kind of ontological violence inflicted by the state, what I like to refer to as the double death of the Black body or retroactive (in)justice.

The Double Death of The Black Body. "One of the most sacred principles" in U.S. criminal law is that the defendant is innocent until proven guilty (Cornell Law School, n.d.). In the instance that the defendant is respectable, like a police officer, the moral character of the victim becomes the object of the trial (Hill, 2020). The defense must present a logical "calculus, a way of sorting oneself and others into categories of those who must be protected and those who are, or soon will be, expendable" (Sharpe, 2017; para. 3). This impact calculus weighs on one hand the fear/stress reaction of an upholder of the peace, and on the other a "villain with supernatural powers who had to be terminated," with a reduced capacity for pain and death (Cobbina, 2018; 79; Maynard, 2018). Fanon (1967) relates this as a function of living while Black where everyday life is a "perpetual insecurity" because you are "inhabited by death," (65) through living "partial progressive deaths" of exclusion and the invisibility of being hypervisible (Fanon, 1969; 12; Cobbina, 2018).

Writer Yawo Brown (2015) contributes to our understanding of the ontologically violent nature of the U.S. Criminal Justice System in linking it as a function of "polite white supremacy" which mars the present with a "Casual American Caste System, Delicate Apartheid, Gentle Oppression, or... after a few drinks: Chad Crow, the super chill grandson of Jim Crow" (para. 1). Brown (2015) shows that beyond physical explicit mandates like the drug war, police rhetoric and framing also play a large and insidiously silent role in mass incarceration and by extension 
police violence in Black and Brown communities. The police and state are submerged in narratives, they rely on the "usage of disingenuous and misleading terminology with subtle double standards" when discussing white suspects and offenders versus Black ones that "continue to permeate stereotypes within news, film, education and music" (Brown, 2015; paras. 17-18). Subtleties in phrasing like "resisting arrest" create cause, mostly false, to inflict violence upon and arrest and imprison Black men. "[W]hen an arm is twisted by surprise at specific angles by a burly officer (or several), any person's involuntary muscular reaction is to correct the pain they're feeling. This is called 'resisting'. What regular person can lie perfectly still as their arm is being broken? Who can pretend to not be in pain?" (Brown, 2015; para. 19). Thus, we can see that every act of violence against a Black body can be easily justified after the fact by criminalizing the very impulses and reflexes to stay alive (Fanon, 1967). First the state kills, then they scramble to justify it using stereotypes; it is a system of retroactive (in)justice. This thesis contributes to this literature by greatly expanding on the analysis of the narrative distancing techniques used by the police Brown (2015) first touches on in The Subtle Linguistics of Polite White Supremacy. While Brown's project was concerned with the experiences of Black men and the police, my project focuses on the subtleties in police rhetoric used in an attempt to conceal and retroactively justify the killings of Black women, using Breonna Taylor as a case study. In order to do so, it is imperative we understand the intricacies of policing, policy, and U.S. settler society that allowed an innocent young Black woman to be executed by the police in her own home so violently her boyfriend remarked later that "it was probably what war sounds like" and it was met with zero legal recourse (Burke, 2020). 


\section{Because She Was Scary-State Violence Against Black Women}

Black women have always represented the greatest ontological threat to whiteness because she was said to be capable of ending the institution of slavery (Jacobs, 2017). Through her womb and English laws of inheritance, any child fathered by Englishmen would have the same rights to inherit land and wealth, they could buy their freedom and that of their family members and friends; slavery would have died out quickly (Browne-Marshall, 2021). Antimiscegenation laws, or those prohibiting interracial unions, arose to preserve the economic system. The Black womb became the first engine of mass incarceration once it became law that any child she had would also be condemned to enslavement (Browne-Marshall, 2021; Ritchie, 2017; Sharpe, 2016).

During the early days of the colonies the fine Christian men who came here for religious freedom were not unmotivated by sexual desires. In the absence of white women, the preAmerican colonial era was marked by the rape and sexual exploitation of Black African women held to bondage (Browne-Marshall, 2021; Ritchie, 2018). Black women have been encoded as "unrapeable," it was not a crime to sexually brutalize an enslaved woman, the first rape legislation defined white women as the only victims (Ritchie, 2018; Jacobs, 2017). Up on auction blocks, Black women were often stripped naked, for the consumption of prospective white male masters (Ritchie, 2018). Once the Transatlantic Slave Trade was banned in 1807 raping Black women was not only legal it "became an economic necessity" (Jacobs, 2017; 44). Throughout the entire history of this nation, we have been subject to the highest propensity of violence, and yet as a society we rarely discuss it because it is barely visible (Ritchie, 2017; Jacobs, 2017). 


\section{Patterns of Police Violence Against Black Women}

Police Sexual Assault. Rates of sexual assault perpetrated by police officers are significantly higher than those committed by the general public, a 6-year period of study showed 1000 officers lost their badges due to sexual abuse (Butler, 2018). The rate of sexual assault committed by police officers is significantly higher than that of the general public. While Black feminist scholars like Andrea Ritchie (2017) have documented police sexual assault against Black women, it took the 2016 conviction of ex-Oklahoma police officer Daniel Holtzclaw for the rape of thirteen Black women for this kind of widespread abuse of power to reach national consciousness (Jacobs, 2017). He targeted only Black women because he knew they were vulnerable; he was betting on the fact that his word as a white police officer would be believed over a Black woman in police custody. This is not an isolated incident, it is normative, there is no region in this country where the police do not sexually abuse and violate women and girls. Officers in the District of Columbia were charged with the rape and prostituting of young girls, all of whom also happened to be Black and vulnerable to a system intent on excluding them (Jacobs, 2017). Often Black women and girls neglect to report sexual assault, in the rare instance that they do report it to the police it can be met with further alienation through criminalization. In 2015 an eleven-year-old Black girl was arrested for filing a false police report for rape, even though she displayed signs of having been sexually assault (Jacobs, 2017).

An Associated Press investigation found that over a six-year time span, there were one thousand police officers who lost their jobs due to sexual abuse (Butler, 2018). This is troubling because there are several states that do not decertify officers for sexual assault. The National Decertification Index arose as a police reform tool, a database intended to name the officers fired for misconduct to help hiring police departments filter out the bad apples from applicants. The 
reason this specific reform has failed women lies in the fact sexual misconduct by officers is largely not framed as a concern. It is not summarily condemned within police culture; it is not required to be disclosed. It is instead framed as personal, with officers claiming the sexual assaults committed against the women in their custody were consensual (Butler, 2018; Jacobs, 2017). What we need is a deeper understanding of the issues in policing that are exclusive to women and other female-presenting people.

Black Women Under Stop and Frisk. Largely absent from the literature until recently is a discussion of Black women as victims of stop and frisk and how it opens them up to unique forms of sexual violence and humiliation that are rarely discussed in the mainstream (Butler, 2018). Black women are often subject to non-consensual cavity searches, often the result of routine traffic stops, that are often conducted roadside in full view of passing traffic (Butler, 2018). Due to this invisibility, no one thinks to prioritize these things in our discussion of police reform. We focus mostly on material violence mainly attributed to Black male victims of police violence, not the psychological or sexual violence that women are more likely to suffer (Butler, 2018). Under stop and frisk, Black women are regularly strip-searched out in the open and given nonconsensual vaginal and anal cavity searches in the name of recovering drug evidence (Jacobs, 2017).

Driving While Superhumanly Black. Black women experience racial profiling in the same way Black men do, pulled over for minor traffic violations as pretext for criminal investigations. These stops always have the potential to be deadly as racial stereotypes of the inherently dangerous and "superhuman" Black body lead officers to choose deadly force as default (Crenshaw, et al., 2015). This is the frame that would cost Sandra Bland her life, she was pulled over for failing to use a turn signal and because the officer felt she had an attitude; she 
was verbally aggressive, he ordered her out of her car and beat her before arresting her. She never came back out of the county jail alive (Davis \& Heilbroner, 2018).

Casualties of The Drug War: Black Women as "Collateral Damage." This pattern emerges and becomes increasingly prominent the further we get into the Drug War mandate; it includes the police interactions with Black women suspected of using their bodies or homes as vessels for drugs. In the latter case, their homes are conceived of as "drug factories or dens of danger and violence" (Crenshaw, et al., 2015). This concept of Black women as the drug mules of Black men has accounted for police shootings that have taken the lives of Black women as young as seven and as old as 92. The "Collateral Damage" frame here allows the police to sidestep responsibility on a second dimension, if a jury fails to buy into the narrative of fear, then at the very least the officer has the ability to say they did not intend to kill her. She died because of her association with a criminal element; a Black male suspect (Crenshaw, et al., 2015). This is the frame that rendered Breonna Taylor's murder by the police invisible for nearly three months (Sloan, 2020). This is the frame I will focus on measuring and understanding through my methodology in the next chapter.

\section{“I Hate That She Had to Die to Be Great:” Breonna Taylor's Legacy as the First Black Woman Martyr}

We say her name, Breonna Taylor, and tell her story now to unabstract the many layers of violence perpetrated against her by the state. In death she became an American symbol. Her mother remarked: "I hate that she had to die to be great," in order for us to see that Black women get killed by the police too (Sloan, 2020). The fluidity and ease the state had in presenting the details surrounding Breonna Taylor's death in order to sidestep any responsibility for it shows us that this ontological violence could not have been aberrant, it was constitutive of systemic 
erasure (Ritchie, 2017). Despite how her death was framed, this kind of negligent violence is not novel like the Coronavirus that also devastated 2020, it is historic and multiplicative and must be addressed and seen as such. This is what the police and the state do and allow to be done to Black women, since the first slave vessel harboring trafficked Africans arrived on these stolen shores. The media is infested with stories and imagery of Black death and violence; it is said that the pervasiveness of these images do not lend themselves to justice or empathy, but rather apathy through desensitization (Stratton, 2018; Sharpe, 2018). What is able to rupture and breach this apathy are images of our bringers of peace slaughtering defenseless citizens.

For Black men, erasure from the state looks like violent physical and political elimination either by death or incarceration, which Alexander (2012) equates to as a "civic death." For Black women, like Breonna, whose contact with the police tend to take place in the private sphere, “away from public view — and cameras — such as homes, clinics and public hospitals, welfare offices, [and] public housing;"' there is simply no documented or eyewitness record of the violence and violation that transpires behind those closed doors (Ritchie, 2017; 234). She is largely invisible because state discursive practices degrade and deny us the ability to notice the endemic and widespread nature of violence against Black women (Ritchie, 2017; King, 2018).

A normative frame to address what happened to Breonna Taylor would be premised on the aesthetic practices of Black women that contribute to their/our deaths, who we associate with; what were we doing/wearing? This is the investigative approach taken by the police after Breonna Taylor was killed. The police shot eight bullets into Breonna; let her lay on the ground unattended until she bled out and died from those injuries. They feigned innocence about their role in her murder when they asked her mother if she and her boyfriend had any known enemies (Taguchi, et al., 2020). As if they arrived on the scene in response to the shooting that resulted in 
her death, rather than created and participated in it. This is how they get away with murder. This is the ontological violence this thesis aims to unabstract.

Under a decolonial approach to discursive and content analysis, this study aims to show that nothing "went wrong" the night she was murdered by the police, this is how the system was always intended to work. To kill Black and Brown people indiscriminately, check box a. or b. describe it as fear-induced or accidental, then they get away with murder. This study looks at how the police are able to "legitimately" claim to murder accidentally by taking the case of Breonna Taylor as a lens to explore the discourses explaining away the police's role in what happened to her. In Breonna Taylor's case, it was said that if the facts and evidence of the case were presented properly there would have absolutely been an indictment made by the grand jury. Charges and personal responsibility would have been placed on the involved officers (Sloan, 2020). This is a very key statement and observation for this study: how did the state and the police present/misrepresent the events that led to Breonna Taylor's murder, in order to sidestep criminal responsibility?

Since violent death requires a sense of reciprocity, the state's ability to dislocate the violent and graphic nature from the act of killing, allows it to avoid a response from the people (Stratton, 2018; 9). This thesis aims to overturn every narrative abstraction, red herring, and "settler move to innocence" (Tuck \& Yang, 2012), used in the Breonna Taylor case, in order to decommission and expose them for what they are: tools of white supremacy. In removing the colonial-powered language, I hope to lay bare how the state managed to avoid taking concrete responsibility for the actions of its agents which led to the brutal and unnatural murder of Breonna Taylor. Breonna Taylor's story broke the mold, and despite the rhetorical practices of 
concealment, a response from the people happened. Breonna Taylor became the face of a new movement, a symbol that change is needed. She became a martyr.

The intent of this thesis is to make explicit the ongoing project of enslavement as it manifests itself in the police killings of Black women without recourse (Sharpe, 2016; Crenshaw, et al., 2015). I rely on news and social media in order to lay bare the hidden dimensions of state violence on the bodies of Black women so that "new meanings and appreciations can be developed to inform, or even re-orient, how we understand [this] experience" (Neubauer, Witkop \& Varpio, 2019; 92). For in the absence of state mechanisms and institutions tasked with tracking and naming police violence and misconduct that is far from exhaustive nor inclusive of the experiences of women, we must turn to the grassroots level and take it upon ourselves the relentless work of unveiling how the colonial matrix of power operates through the police on Black femme bodies. So that we might quantify and name the instances of Black female death and exclusion from humanity when we see it, with the intent of publicly shaming our institutions, politicians, and state actors to stop killing us with impunity. Karl Marx (1843) defines shame as "a kind of anger which is turned inward;" it is an internal revolution.

In all major movements towards equality, life, and joy: women's suffrage, Civil Rights, Pride (queer rights), and Black Lives Matter, Black women were central to the negotiations (Hill, 2020). I stand on the shoulders of giants, pioneers of freedoms they were never entitled to experience. Who toiled, fought, and resisted so Black men and later white women could vote before them. So white men could be gay and proud. For society to recognize police killings of Black men as systematic rather than aberrant. Today, we owe it to the Black women who silently endure the genocide of coloniality, the rape and murders no one is ever charged for because it is invisible. We owe it to Black women to try to create societies where they can live justly and 
freely, with the security of knowing there is a material recourse when we are harmed. This is the presentation of a positive world peace. When Black women's lives are affirmed it signals the end of the road to our fight, it means Black men and white women have already been liberated. By speaking these long-held silences into consciousness, I intend this work to help us build this long-denied dialogue. 


\section{CHAPTER III: METHODS}

For nearly two months Breonna Taylor's death was relatively invisible, suddenly in May of 2020, there was a spike in media coverage and concern. In this visibility, Breonna Taylor received what I coin here as a narrative afterlife. Afterlife being "a period of continued or renewed use, existence, or popularity beyond what is normal, primary, or expected" in our justice and reform discourses (Merriam-Webster, (n.d.)). This study used both qualitative and quantitative forms of content analysis to uncover Breonna Taylor's narrative afterlives, their uses and misuses, and significance. To do this, I employed a content analysis of the media coverage of Breonna Taylor over a one-year period, starting on the day of her death March $13^{\text {th }}, 2020$, through the one-year anniversary, March $13^{\text {th }}, 2021$. Secondarily this study aims to illuminate the contexts, key factors, and events, that worked to conceal what happened to her and those that worked to uncover and bring visibility to her case. The following sections discuss the study design, research question and hypotheses, sampling, and data analysis. This chapter ends with a consideration of the relative strengths and weaknesses of the study design and methodology.

\section{The Study}

In the wake of institutional and systemic silences and erasures, this study uses a phenomenological approach to understand how the police killing of Breonna Taylor managed to capture international attention and concern when all other Black women victims barely managed to receive local attention. Phenomenology, developed by Edmund Husserl, is a philosophical methodology for the investigation of consciousness (Wertz, et al., 2011). It relies on understanding the way language and symbols are used to construct aspects of society through what is known as "symbolic interactionalism" (Wertz, et al., 2011). This thesis also uses grounded theory to unpack the phenomenological. Grounded theory is a comparative 
methodology of data analysis in sociological theory, that allows social processes to be explained by analyzing society as a set of social constructs (Wertz, et al., 2011). I chose the news media as my unit of measurement as its focus on the spectacular will allow an investigation into the kinds of spectacles/events it took for Breonna Taylor to be recognized as a victim of state violence in need of justice. As stated in the last chapter, language emerges from experience and also gives shape to them; bringing subjective meaning (Valencia, 2018; Wertz, et al., 2011). This study embodies these methods by using a content and discursive analysis as part of a narrative inquiry that focuses on "the performative aspects of language;" to unpack how stories about Breonna Taylor have been used and for what purpose (Wertz, et al., 2011; 62). It is not enough that we understand what is being said about Breonna Taylor, we must also consider how her story is framed and the contexts that produced them that are presented within the news. This study attempts to understand the narrative afterlives of Breonna Taylor by conducting a media content and discursive analysis of the news media coverage of her to understand how the media created the first Black woman martyr.

\section{Content and Discourse Analyses}

Lasswell (1948: 117) says that a content analysis allows us to explore "who says what through which channel to whom with what effect." This methodology allows me to understand the meaning or cultural/political impact Breonna Taylor's murder has had on society within the context of the symbols and attitudes presented about her in the media (Krippendorf, 1989; Saraisky, 2015). This study uses media as the content of analysis for a few key reasons: first, because media has been historically instrumental in the dissemination of stereotypical and dehumanizing imagery of Black people in this country (Alexander, 2012), second, its role in interpreting and communicating ideas about public policy, and third, its role in gatekeeping who 
and to what extent individuals can comment on and proffer solutions to social issues (Saraisky, 2015).

\section{Research Question}

What are the narrative afterlives of Breonna Taylor?

\section{Hypotheses}

Hypothesis $1(\mathrm{H} 1)$ : Breonna Taylor's revival in the media following the death of George Floyd was a narrative tool to make police killings and brutality against Black Americans more palatable and important to white moderate audiences.

Hypothesis 2 (H2): Some media used framing to make us question whether Breonna Taylor was a legitimate victim of police violence to undermine the Black Lives Matter protests and activism.

\section{Hypothesis Testing and Measurement}

J. Brendan Shaw’s (2019) "Sandy Still Speaks: The Digital Afterlives of Sandra Bland" offers a way to assess the "liberatory potential of Say Her Name" (8) by understanding the prevalence of narrative framing of Bland's story that had the intent of securing white empathy for the sake of political neutrality. The study sought to examine the "visual remains of Bland" in order to see how her "digital afterlife is constantly [being] curated" (Shaw, 2019; 3). These ideas helped me to conceptualize what and how I intended to measure the media coverage of Breonna Taylor. This study used the headlines of articles written about Breonna Taylor, as a stand-in for article content (Bhatia et al., 2013), to quantify and qualify the kinds of narrative frames that attempted to make what happened to Breonna Taylor more palatable for moderate white audiences. That is, how was Breonna's life and legacy watered down for her to meet white respectability frameworks? Conversely, this study also sought to understand the inverse, by 
looking at what kinds of frames and the extent that they were utilized in the media to disqualify her as a victim of state violence. Specifically, here, what kind of framing was used to shift the blame of what happened to her that night from the police.

\section{Data}

An advanced "news" field search on NexisUni for "Breonna Taylor" within the "headline and lead paragraph" between the date range of March 13, 2020-March 13, 2021, was run. The search was further filtered by "English language only" and the following publication types: "newswires and press releases," "newspapers," and "web-based publications." From this initial exploratory search, I yielded over 10,000 results. To narrow down these results to create a manageable and inclusive sample size the year long period of study was broken down into 12 one-month periods (see table 1 below) so that the sample could equally represent each month. This also highlights Breonna's visibility and our concern.

\begin{tabular}{|c|c|}
\hline \multicolumn{2}{|c|}{ Article Dispersion } \\
\hline Date Range & Frequency \\
\hline $3 / 13 / 20-4 / 12 / 20$ & 1 \\
\hline $4 / 13 / 20-5 / 12 / 20$ & 4 \\
\hline $5 / 13 / 20-6 / 12 / 20$ & 1816 \\
\hline $6 / 13 / 20-7 / 12 / 20$ & 1197 \\
\hline $7 / 13 / 20-8 / 12 / 20$ & 535 \\
\hline $8 / 13 / 20-9 / 12 / 20$ & 766 \\
\hline $9 / 13 / 20-10 / 12 / 20$ & 3564 \\
\hline $10 / 13 / 20-11 / 12 / 20$ & 518 \\
\hline $11 / 13 / 20-12 / 12 / 21$ & 200 \\
\hline $12 / 13 / 21-1 / 12 / 21$ & 303 \\
\hline $1 / 13 / 21-2 / 12 / 21$ & 168 \\
\hline $2 / 13 / 21-3 / 13 / 21$ & 332 \\
\hline
\end{tabular}

Table 1. Article Results Frequency and Date Dispersion

Each search's results were further sorted by "relevance," as a simple method of randomization, and the first 30 articles were drawn from each period to serve as the study 
sample. Since the preliminary investigatory search showed only a single news article about Breonna Taylor prior to May 2020, I chose to add "blogs" to this search parameter to see if civilian/grassroots journalism would have given Breonna news coverage when the larger national publications overlooked her and found no additional results. So to supplement this and ensure I had a more representative sample I also used the local newspaper The Louisville CourierJournal's early coverage of the case. Following this I had a sample size of $310(\mathrm{~N}=305$ NexisUni articles +5 supplemental). However, from those 305 randomly chosen articles I knew I would need to remove duplicate articles, those that were news briefs and summaries and those that were not actually centered on Breonna Taylor, which not come to light until the coding process. In all, 104 articles were removed from the initial sample giving a final sample size $\mathrm{N}=206$. Previous similar news media content analyses used sample sizes between 140 and 250, showing that my sample size was adequate and in line with the literature base (Bhatia, et al., 2013; Habel, Liddon, \& Stryker, 2009).

\section{Methods and Analysis}

The units of analysis for this study were the headlines of the Breonna Taylor centric articles, as well as the lead paragraph (if she is introduced by name in the body of the article rather than its headline), the introductory statement that introduces the reader to Breonna's case (if separate), and the thesis statement within each article. These pieces of information were chosen to fully "assess the tone and motive of the article" (Bhatia et al., 2013; 589; Krippendorf, 2004; Hsieh \& Shannon, 2005). The content analysis was conducted through electronic coding using the Nvivo software. There were three initial predetermined coding categories: Assigned Value, Innocence, and Retaliatory Violence/Police Are Under Attack frames. The Assigned Value frame can be operationalized as any narrative/frame meant to qualify to the audience why 
they should care about Breonna Taylor, these include references to her job as an EMT, the fact that she was an aspiring nurse and a frontline essential worker in this pandemic. Innocence frames here are defined as those with the intent of neutralizing her, these include those that claim she was sleeping, or in her own home at the time of her murder. Finally, the Retaliatory Violence frame includes those that attempt to demonize the protests that emerged following visibility of her case by equivocating new instances of violence against police officers as a direct result of our awareness of her case.

These three initial narrative frames are not meant to be exhaustive but rather a means of combining both directive and summative content analysis types. A directive approach uses theory or the literature about a phenomenon as a baseline for study to expand our understanding of it (Hsieh \& Shannon, 2005). Summative content analysis works by "identifying and quantifying certain words or content in text with the purpose of understanding the contextual use of the words or content," to explore usage and prevalence rather than to infer meaning (Hsieh \& Shannon, 2005; 1283). This allows for the identification of alternative frames or subcategories/codes to examine the contexts that produced certain framing devices and language usage. As previously stated for the purposes of this study, the theoretical foundation of this study is based in Black feminism as an analytic conscious to explore the historic and still present issue of Black women's definitional exclusion from the frameworks and structures of justice (Jacobs, 2017). This will help focus the research question and afford us predictions about the variables in question, this also increases reliability by not being over limiting, to capture a fuller picture of possible narrative frames (Hsieh \& Shannon, 2005). In addition to studying the initial frames I hypothesize to be the most prolific in discussing Breonna Taylor, new themes/frames were added to the list of codes after the fact if they were found to be in use at least four times. 
Quantitatively, this study looks at change over time by first noting the number of articles that appear in the Nexis Uni search results by each date range. This offers the simplest way of understanding what events/factors seemed to have brought the greatest visibility to Breonna Taylor's case and circumstance. This quantitative part of the data is meant to measure the way Breonna Taylor was initially rendered invisible and the forces and events that allowed us to finally see her. Of interest here is the difference in coverage of George Floyd and other male victims of police brutality versus Breonna Taylor and other female victims of police brutality, as well as the prevalence of my initial frames compared to any new frames that emerged over the course of the study. This study separately tracked every mention of George Floyd, Ahmad Arbery and other male victims of police brutality that appeared throughout the sample, as well as the Black women victims like Sandra Bland, illuminated by the Black Lives Matter movement. This frequency tracking shows the great disparities in visibility as well as their staying power in our consciousness as reference points of racial injustice between Black male and women victims.

The supporting and non-supporting evidence of my theory will be presented in the next chapter using the settled upon codes and examples and descriptive evidence of them. Following this, in the final chapter I will use my previously stated theoretical foundations to guide discussion of my findings. All of the above analysis was then combined in order to definitively tell the story of the forces that coalesced to bring the police to Breonna's door, force their way inside and kill her and not face any criminal consequences or personal liability.

\section{Reliability}

Content analysis is a cheap and flexible way to analyze textual data in order to offer a descriptive method of the phenomenon of study from which inferences can be made. There is the possibility that in taking a directive approach to content analysis a potential overemphasis on the 
theoretical considerations "can blind researchers to contextual aspects of the phenomenon" (Hsieh \& Shannon, 2005; 1283). In taking a mixed approach to content analysis I hope to better avoid researcher bias due to my informed status and theoretical understanding behind the research questions. Using fewer predetermined codes, three rather than the more normative five to seven within the literature base, I hope to avoid my internal confirmation bias that could lead to finding subtle justifications that present the evidence as largely being supportive of the hypotheses rather than unsupportive, by taking a looser more exploratory approach.

As a project with a single researcher, issues of reliability from reproducibility arise, as there is no way to ensure all coders would assign the same meaning to the same excerpts (Columbia Public Health, (n.d.)). Scholars have argued about the reliability of performing content analyses with the goal of assessing media frames (Matthes \& Kohring, 2008). This is due to the nebulousness of what a frame actually is; they are difficult to identify and code in particular. As such it is difficult to neutralize the impact of the researcher (Matthes \& Kohring, 2008). However, reproducibility, if also conducted using this study's Black feminist framework allows the space for self-reflexivity to intersectionaly view the importance of specific framing devices. Simply, it is expected that someone of a different background from me would not always find significance in the same facets as I would. This is due to the fact I might, as a Black woman based on my past experiences and the vicarious experiences of those in my social circle, make me sensitive to less explicit forms of silencing and diminishing of Black women that a white man or woman or even Black man may be completely oblivious to. 


\section{CHAPTER IV: RESULTS: THE SEVEN NARRATIVE AFTERLIVES OF BREONNA}

\section{TAYLOR}

Since May of 2020, millions around the world have been saying the name Breonna Taylor and demanding justice for her. For the right to sleep while Black without the fear of being killed by the police. The Say Her Name campaign that began in 2015 was initially used by Breonna's family in the wake of the lack of publicity, transparency, and justice that came out of what happened to her (Crenshaw, et al., 2015; Romano, 2020). In order to process and channel her grief, Breonna's sister, Ju'Niyah Palmer, began the \#Justice4Bre social media movement to raise awareness and humanize Breonna, to fight for her sister in a way the mainstream Black Lives Matter movement never would (Romano, 2020; de la Cretaz, 2020; Crenshaw, et al., 2015). Gender bias and anti-Blackness in justice, combined with the newly unfolding (at the time) Coronavirus pandemic worked together to render the murder of Breonna Taylor invisible (de la Cretaz, 2020; AP Newswire, 2021). The death of George Floyd in Minnesota months later followed by the release of boyfriend Kenneth Walker's "chilling 9-1-1 call" three days after that would prove to be what it took to bring interest to Breonna's case (AP Newswire, 2021).

Despite the visibility Breonna's family sought to raise about what happened to her, the first narrative most of us heard about the police killing of Breonna Taylor was still false. The first widely-circulated narrative of Breonna's death emerged in the wake of George Floyd's death, it was presented as if anti-Blackness in policing was so surface level that even her sleeping form elicited enough fear for the police to execute her on sight. As such, the protests that emerged in her name did not begin until May 28, 2020, three days after the death of George Floyd -three months after she was killed (Costello, et al., 2020). This study began to solidify as I pondered how and why the misinformation about the Breonna Taylor case began. The question 
this thesis aims to answer through exploration of the media narrative afterlives of Breonna Taylor is what kinds of depictions of her persist, who is propagating them, and for what audience? That is, what are some possible reasons for her posthumous popularity? To do this, I looked to the news media to better understand the predominant depictions that existed of Breonna Taylor within the universe of English language news coverage. This chapter is not meant to provide a literature review of the media coverage of Breonna Taylor. It is, instead, a critical analysis of how the media (whether intentional or not) frames and leads us to perceive Black women victims of police violence, explored through the lens of the evolving news coverage/framing of Breonna Taylor.

This chapter seeks first to orient the reader, to the best of my ability, to the events that led the police to Breonna's door to ultimately kill her, leaving a family, community, and sense of justice irrevocably shattered. Following this, I offer an overview and descriptive/quantitaive summary of the data before moving onto the qualitative analysis of the data through the exploration of the seven most prolific narrative afterlives of Breonna Taylor. The last section offers a discussion of the study results as they compare to my hypotheses.

\section{Understanding the Killing of Breonna Taylor}

The story of Breonna Taylor's final moments has been dubbed "a tale of two points of view from either side of the same door" (Sloan, 2020). Due to this, I find it imperative this chapter formally begin with the carefully curated story I composed of what happened to Breonna Taylor. This is the sequence of events this thesis used as a baseline from which the collected data narratives were compared to in order to assess the accuracy and potential bias of the media coverage. This story seeks to chart the entire linear path of Breonna's entanglement with the 
Louisville police, beginning with how they would come to know the name: Breonna Taylor. A year before her death in March 2020, the Louisville Metro Police Department (LMPD) found itself in the spotlight for racial bias when a video depicting the police stop of a Black male high school student went viral (Barbaro, et al., 2020a). To combat the negative image of the department following this incident, the LMPD's chief reached out to a policing expert to usher them into a new era, past anti-Blackness in policing. The University of Cincinnati professor suggested that Louisville adopt the use of Geographic Information System (GIS) crime mapping to find micro locations of high crime to target rather than continue to over police entire Black and Brown neighborhoods. The area that proved to stand apart from the rest was the 2400 block of Elliot Ave., specifically one house, a drug house operated by Jamarcus Glover, Breonna Taylor's ex-boyfriend. It is this incomplete performative/counter frame reform effort that would set into motion the events that brought the LMPD to Breonna's front door to ultimately kill her (Barbaro, et al., 2020a).

Breonna is formally brought into the police's crosshairs once Jamarcus Glover pulled up to the heavily surveilled drug house on Elliot Ave. in her car. At this point the LMPD's investigation into Glover's activities expands to include Taylor as well. For the year leading up to her murder, the police watched Breonna; following her to gather intelligence for the raid that would result in her death. The LMPD had ample evidence Breonna would be unarmed and nonviolent, yet they still asked for that fateful no-knock search warrant anyway, and a judge signed off on it. Hours before the warrant on her home was executed a police briefing was held, during this meeting the no-knock warrant issued for Taylor's apartment was amended to a knock and announce (Barbaro, et al., 2020a). 
An hour after Breonna Taylor and her boyfriend Kenneth Walker arrived home from a date on March 12, 2020, at around 22006 (10 p.m.) the LMPD arrived at Taylor's home for some last-minute surveilling. The police saw through the window Breonna was at home watching tv. The police also thought Breonna was home alone and still they chose to carry out the raid as if they believed Glover was in the home (Barbaro, et al., 2020b). At around 0035 (12:35 a.m.) three plainclothes officers lined up at Taylor's door. Officer Hankinson is said to have broken from that formation seeking a different angle. He walked around the home and to the back patio facing the sliding glass door. Five minutes later at 0040 (12:40 a.m.), the two officers who remained at the front door, Mattingly and Cosgrove, began knocking aggressively.

Breonna, half asleep, is said to have repeatedly yelled "who is it?" and after receiving no answer Breonna and Kenny began to panic, assuming that Glover is on the other side of the door. Months prior, Breonna's ex, Jamarcus Glover, arrived at her home to harass her, aggressively banging on the door and not giving a response when asked who it was. Kenny, who is so disoriented he puts on Breonna's pants instead of his own grabbed his gun before he and Taylor began walking to the front door. On the other side of that front door the police began using the battering ram and three short blows later the police breach the apartment to reveal a terrified Walker and Taylor at the end of the hall. Afraid, Kenny lets off a warning shot with his gun, Mattingly is hit in the leg by the bullet. Mattingly notes that at this point he quickly began firing shots of his own as does Cosgrove (Sloan, 2020). Hankinson, still out on the patio cannot see what is happening inside due to the blinds but upon hearing the gunshots from within the apartment he too began shooting — blindly_through the covered glass door. After firing 32

\footnotetext{
${ }^{6}$ Here I defer to the use of military time for two reasons: first, to avoid confusion as the events that unfolded happened over the course of two separate days and to highlight for the sake of the narrative the militarized nature of this particular policing practice that left a woman dead.
} 
rounds into the apartment, the officers stopped shooting and delivered aid to Mattingly. The officers called for an ambulance, before Cosgrove leads Mattingly outside the apartment to the ambulance. Kenneth Walker and Breonna Taylor were left alone and unattended inside the apartment, none of the three officers checked to see what became of the two inhabitants of the home, whether either of them needed medical attention as well (Barbaro, et al., 2020a).

Confused and in shock, Kenny called his mother at 0046 (12:46 a.m.) for assistance, she advised him to call 9-1-1. At 0047 (12:47 a.m.) Walker called 9-1-1 for help because unknown intruders came in and shot his girlfriend Breonna Taylor. This phone call was the first-time the police were made aware that a woman in the house was injured. After hanging up on 9-1-1, Kenny called Breonna's mother Tamika Palmer to tell her what happened. While on the phone with Ms. Palmer, Kenny hears voices outside, he thought the police had arrived to help not frame him. Kenny then tried to walk outside to let the first responders in and was greeted by guns pointed in his face (King, 2020). The police yell at Walker to walk backwards to the police car, it is that moment he remarks realizing the "intruders" were the police (Barbaro, et al., 2020b). As Kenny followed orders to walk outside, he recounts that an officer asked if he had been hit by a bullet, when Walker replied "no" the officer responded that that was unfortunate (King, 2020). Kenneth Walker was then dragged out to the waiting police car. It was cold and wet, and Kenny was barefoot, his feet were getting sliced up by the gravel and no one would tell him anything. Shortly after getting off the phone with Kenny, Breonna's mother Tamika Palmer got dressed and drove over to Breonna's apartment to find out what was going on (Haines, 2020). The police gave her no answers. Instead the LMPD send her to the hospital with false hope, that daughter would be there, alive. In reality, Breonna was still inside the apartment, dead. After finding that Breonna is not at the hospital, Ms. Palmer went back to the apartment for 
information, but the police still would not tell her much of anything. At this time the police started asking Palmer questions: whether Breonna had any enemies or if she was having issues with her boyfriend, present tense, before the police finally told Ms. Palmer that her daughter was dead (Haines, 2020). At around 0500-0600 (5-6 a.m.) the LMPD told Walker he was being charged with the attempted murder of a police officer; they did not tell him anything about Breonna. Kenny recounts how later that morning in his cell he overheard a news report playing on a nearby tv that Breonna had died (King, 2020).

When viewed as part of a whole, rather than an isolated event, it is clear that contrary to what the LMPD claim, what happened to Breonna Taylor was a race thing, and it was also a woman thing (Sloan, 2020; Crenshaw, et al., 2015). Kenneth Walker fired a single shot in warning to stand his ground and protect his home, the police fire 32 shots in return. Kenny's instinct was to crouch and hide, not return any shots, yet he is still shown no humanity or care as he is dragged to a police car like an animal. These events and actions will prove to be important as we delve deeper into this chapter and in the data analysis of conflicting narratives.

\section{Framing Breonna: Unpacking the Media Narrative Afterlives of Breonna Taylor}

The initial coverage of Breonna focused on her almost secondarily; her death is treated like an afterthought to that of George Floyd or the high-profile celebrities demanding justice for her. Due to this, I tracked what paragraph in the articles Breonna is first mentioned, see table 2. While the vast majority of news articles mention Breonna Taylor in the first paragraph, and it is not of statistical significance, it was worth noting that in 14 out of 206 articles that feature the name Breonna Taylor in the headline, she is not centered in the story itself, almost as if her name is being used as clickbait. It took until September, when Breonna's family won the wrongful 
death lawsuit and the Grand Jury proceedings occurred, that there begins to be storytelling that is actually centered on Breonna Taylor the individual.

As stated previously, this thesis utilized a directive approach to content analysis meaning I began coding with the three predetermined codes: assigned value, innocence, and retaliatory violence as drawn from my two hypotheses (Hsieh \& Shannon, 2005). Hypothesis 1 (H1): Breonna Taylor's revival in the media following the death of George Floyd was a narrative tool to make police killings and brutality against Black Americans more palatable and important to white moderate audiences. Hypothesis $2(\mathrm{H} 2)$ : Some media used framing to make us question whether Breonna Taylor was a legitimate victim of police violence to undermine the Black Lives Matter protests and activism. With these hypotheses in mind, I set out to systematically electronically code all 206 articles in my data sample using NVivo. I discovered 23 other codes for a grand total of 26, depicted and described in detail in table 2.

Two codes "references to Black male victims," and "inaccurate info" were excluded from the concept map I developed in order to reveal the seven narrative afterlives of Breonna Taylor because they but did not help to answer my research question. Throughout the entire sample of news articles $(\mathrm{N}=206)$, there were 218 references made to other Black male victims of police brutality and anti-Blackness in U.S. justice, the most prolific names being George Floyd, Ahmaud Arbery, Trayvon Martin and Rayshard Brooks. There were three instances when inaccurate facts were stated, of note is that the articles within the sample that presented inaccurate data, all were from U.K. based publications. Two articles falsely naming the date of Breonna's murder as having occurred on March 16 and March 26 respectively (Stern, 2020; de Menezes, 2020). One article published in September 2020 goes as far to state "Ms. Taylor died two months after the death of George Floyd" (Higham, 2020). 
These inaccuracies can likely be attributed to the huge delay in attention her case received initially. Under my search parameters in NexisUni, there were only five total articles featuring "Breonna Taylor" in the headline and/or lead section from 3/13/20-5/12/20. The first article this sampling method yielded was published April 13, 2020, a month after she was killed, it had the headline: "LMPD officers criticize judge for releasing man who initiated shootout that caused woman's death; suspect's lawyer has different story to narrate" (Legal Monitor Worldwide, 2020). The next four headlines come from articles published a month after that on May 11, 2020, and May 12, 2020, respectively, their headlines as follows, save for one, equally conceal Breonna's identity and humanity:

Breonna Taylor: Black healthcare worker 'shot at least eight times by police' in own home, lawsuit says; Police claimed they were executing a drug warrant when shooting took place (Hall, 2020).

A Kentucky EMT was shot and killed during a police raid of her home. The family is suing for wrongful death (Jones, et al., 2020).

Attorney for Ahmaud Arbery's Father Now Represents Family of EMT Killed in Allegedly Botched Raid (Luperon, 2020).

Family of black EMT, 26, sues police after she was shot 'at least EIGHT times' in the middle of the night in her Kentucky apartment during 'botched' drugs raid for man who was already in custody (Fruen, 2020).

By looking at the early framing of Breonna's story within the sample, it is easy to see the way she is essentially erased from her own narrative; she is not a tangible formerly living woman but her role. We can also see how the framing and oversimplification of the story deviates tonally from the full story of what happened. It can be concluded that the abstraction and distortion of Breonna Taylor in this early coverage, in relation to when the coverage becomes widespread, following the killing of George Floyd, provides the perfect stage for this kind of misinformation to proliferate within the news. 


\section{The Seven Narrative Afterlives of Breonna Taylor}

The first four codes I encountered emerged together in the early coverage: "assigned value," "references to Black male victims," "innocence," and "failed raid." These codes encompass four of the top six largest codes in terms of frequency, indicating that these frames persist through the entirety of the news coverage of Breonna Taylor. The next major era of media coverage began in June, these codes were oriented around raising the profile of Breonna's case through efforts to increase awareness of it and apply pressure on the state to take concrete action against the individuals for what happened to her. These codes included "celebrity activism," "BLM," "Say Her Name," "delayed justice," "lack of accountability," and "retaliatory violence 1." After this the coverage starts to become more thematic and investigative rather than episodic, they look toward the bigger picture instead of just events. This phase in framing the Breonna Taylor case shows a linear story of evolving news consciousness, it begins with episodic reporting as traced through the "police reform/accountability" code which is later explored in greater depth through the exploration of "nationwide policing practices." Once the Grand Jury decision not to hold the involved officers personally or criminally responsible for Breonna's murder is revealed, the following exploratory codes start appearing: "lack of police accountability," "larger government corruption," and "systemic failures." The codes "LMPD take no responsibility" and "retaliatory violence 2 " lead directly to coverage that held allusions to the fact U.S. justice is empty tracked through the "performative justice" code. The last major code to emerge is "Breonna's legacy," reporting under this frame is oriented around exploring her impact on the criminal justice system and its legitimacy as well as societal consciousness. 


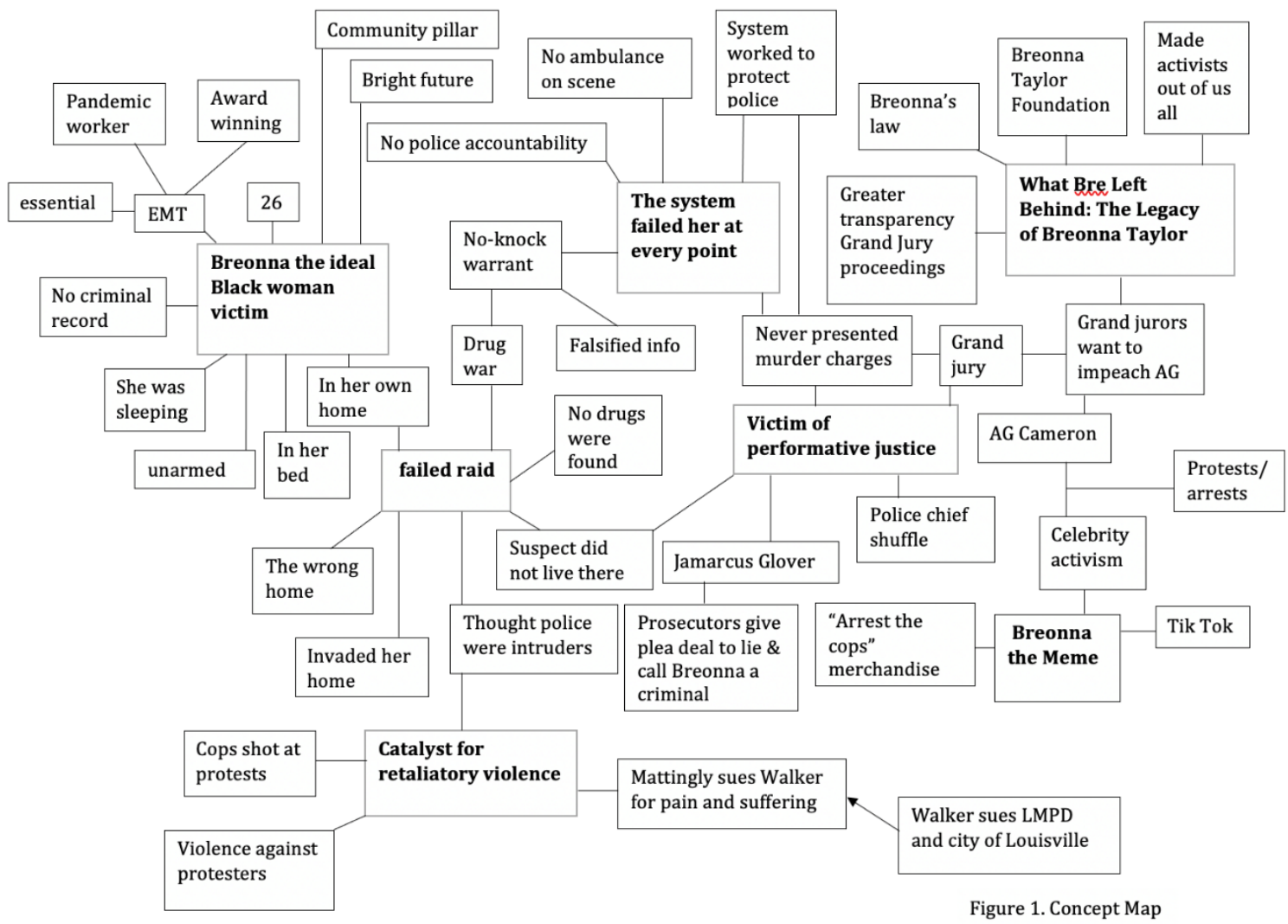

Following the coding process, I developed a concept map, see figure 1., connecting the many stories the news article sample depicted which illustrated seven main micro narratives ${ }^{7}$ about Breonna Taylor. The codes (see table 1 in appendix) were then sorted and divvied out amongst the seven narrative frames identified in the previous step (see figures 2-8). The seven narrative afterlives of Breonna Taylor are as follows: 1.) Breonna the Ideal Black Victim; 2.) Breonna the Victim of a Failed Raid; 3.) Breonna the Meme; 4.) Breonna the Victim of (In)Justice; 5.) Breonna the Catalyst of Retaliatory Violence; 6.) Breonna the Posthumous Victim of Performative Justice; and 7.) Breonna the Inspiration for Change. These seven micro narratives will be presented not in the order of size/prevalence but rather how they

\footnotetext{
${ }^{7}$ This thesis employs the term micro narrative to describe the way in which Breonna Taylor's life and death was narratively broken into pieces by the media to position us to view her in a specific way.
} 
chronologically emerged as time went on. This method was chosen to depict the evolution of our fixation on Breonna Taylor, specifically what facets of how Breonna lived and died stood out first then over time and reflection, what other things became important or came to light?

\section{Afterlife 1: Breonna the Ideal Black Victim}

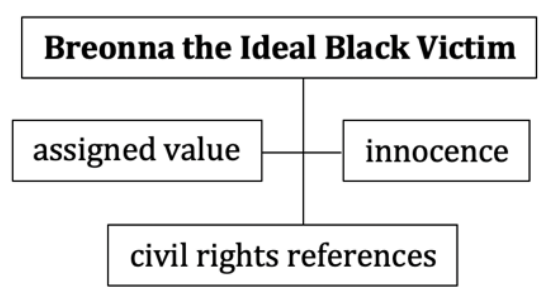

Figure 2. Afterlife 1 Code Tree

The first afterlife to emerge was this one, it is rooted in the historical context and composed of three codes: "assigned value," "innocence," and "civil rights references." This afterlife focuses on the positive attributes of her identity/background as well as her actions that night. It seeks to qualify to the reader why they should care about the death of a woman in Louisville, Kentucky; setting the stage to position her as a martyr in this new civil rights movement. Rosa Parks was far from the first Black woman to refuse to give up her seat to a white person on a bus, yet her act of defiance would prove to be a major flashpoint for a social movement (Alexander, 2012). Alexander (2012) guides us to understand Rosa Parks' significance in the history of Black liberatory activism is not for what she did but rather who she was when she did it. Rosa Parks stood out to be the public face because she played into white respectability frameworks. This afterlife draws on the role of Rosa Parks as an ideal plaintiff for challenging segregation as theory or historic precedent for Breonna Taylor's positioning as a martyr for the Black Lives Matter movement. This frame will illustrate that Taylor's prominence in the media is largely due to the need to only tell "stories of racial injustice that will evoke sympathy among whites" (Alexander, 2012; 227). There were five references to the 1960s Civil Rights Movement, note 
that of the five mentions to the Civil Rights Movement all referenced Black male leaders specifically Martin Luther King Jr. and Malcom X and no Black women.

Assigned Value. The assigned value code appeared 116 times, it sought to introduce the reader to Breonna. The top recurring qualifications used mainly focused on her job, as if her career in healthcare should have had the ability to transcend her Blackness and ultimately save her life. The references to Breonna Taylor under this code repeatedly refer to her as a "26-yearold EMT," “essential worker” and “aspiring nurse” (Hall, 2020; Jones, et al., 2020; Higham, 2020; Mamo, 2020; Vibe, 2020; Lovan, 2020; Mystal, 2020; Hansen, 2020; Paybarah, 2020; Leishman, 2020; Ruiz, 2020; Chudzinski, 2020; Sommerlad, 2021; Steiner, 2021). This play on respectability politics informs us how deeply entrenched anti-Blackness is institutionally. This code sought to explain why, under this framework, she should still be alive today, meeting my first hypothesis. There are only two other codes that appear more frequently, the failed raid and comparisons/references to Black male victims of systemic anti-Blackness. References to her role in her community included the following:

A decorated Emergency Medical Technician (EMT) was repeatedly shot and killed in her own home by Louisville police officers...the aspiring nurse... had been working as an EMT in Louisville amidst the coronavirus pandemic as an essential worker, helping to save lives during the public health crisis (Hall, 2020).

Taylor - who had no criminal record and worked for two local hospitals - was killed after police fired at least 20 rounds into the home (Fruen, 2020).

She worked for us during the covid pandemic (Kaufman, 2020).

A pillar of her Kentucky community (Bunch, 2020).

The murdered Black first responder (Rowley, 2020).

Breonna Taylor was a young woman with a bright future... planned to have a long and fulfilling career in healthcare after working as an EMT; She wished to become a nurse, buy a home, and start her very own family (Young, 2020). 
She had plans. Plans for a future filled with responsibility and work and friends and laughter (Perano, 2020).

An innocent woman being killed by the name of Breonna Taylor. A woman who had a bright future (Amatulli, 2020).

[Breonna Taylor was a] healthcare worker from Kentucky, who spent her life caring for others (Blue Virginia, 2020).

An EMT, who risked her life every day on the frontlines of the COVID-19 pandemic (Targeted News Service, 2021).

These references to Breonna, particularly those mentioning her role in the then emerging Covid19 pandemic, seem to indirectly highlight that ironically the state did not give Breonna the same level of care she extended to members of her community.

Innocence. The innocence code appeared 71 times, it included phrasing with the effect of neutralizing Breonna and her actions that night, to reiterate to the audience that she absolutely should not have died that night. This code traced themes like "in the sanctity of her own home," (Vibe, 2020) making sure to remind us that she was unarmed and had no criminal record like if she was in possession of any of these things as well as consciousness the police would have room to justify their actions.

Many articles, like the following, relied on the idea that she was shot as she slept in bed for the crime of being born of Black skin, larger excerpts include:

Breonna Taylor Was Murdered for Sleeping While Black (Mystal, 2020). HL

Cops were shooting at a sleeping Breonna (Waddell, 2020).

Taylor, 26, and her boyfriend Kenneth Walker, 27, were in bed at the time and thought they were the victims of a home invasion (Dillon, 2020).

She was asleep and unarmed (Iasimone, 2020).

In her own bedroom (Kaufman, 2020). 
It is hard to sleep at night knowing that Brett Hankison is comfortable in his own bed, in his own home - four months after his bullets killed Breonna Taylor while she tried to do the same (Bunch, 2020).

fatally shot while asleep (Rowley, 2020).

while she was at home in bed (Alexander, 2020).

who was sleeping in her bed when cops raided her home and shot her multiple times, Taylor died for quite literally no reason... Black woman can't even sleep in her own home innocently without the fear of police shooting her dead? (Leishman, 2020).

while she was asleep in her home (Young, 2020).

shot eight times while sleeping in her bed (MaGee, 2020).

Breonna Taylor was killed in her own bed by police (Targeted News Service, 2021).

Many more articles qualify Breonna's sense of place when she was killed there were 27

references made throughout the sample qualifying that Breonna was killed "in her Kentucky apartment," or "inside her own home" (Fruen, 2020; Bunch, 2020; Hair, 2020). Some articles took this qualification of Breonna's space/place further to overemphasize to the reader that Breonna in no way provoked what happened to her. These depictions assert things like:

Taylor was killed on March 13 when officers burst into her apartment in the early morning hours. She had been asleep moments before her death (Mulraney, 2020).

They barged into her home without knocking and shot her in her sleep... she was an innocent civilian (Kaufman, 2020).

She was not a primary suspect, nor were there any drugs recovered from her home (Targeted News Service, 2020).

'Breonna Taylor's life was taken while she was in the comfort of her own home, through the use of a no-knock warrant. While Taylor was not the subject of the warrant, her life was mercilessly ended through no fault of her own (Holmes, 2021). 


\section{Afterlife 2: Breonna the Victim of a Failed Police Raid}

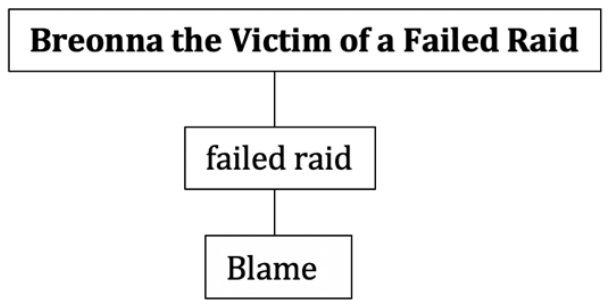

Figure 3. Afterlife 2 Code Tree

The widest used narrative is that of the "failed raid" it appeared 194 times. The failed raid frame is largely how the media has chosen to explicate why the police were even at Breonna's home that night to kill her and damage the property of her neighbors. This code traced the frequency of the use of failed, mistaken, or botched raid or any similar iteration. Upon reading the full narrative of the events that led up to the police's murder of Breonna it becomes clear, the raid was calculated and no part of it was accidental, save for the fact it ended in a death and an officer being shot. Over time a subcode was identified, "blame," this code expanded on the failed raid narrative by characterizing why the raid failed. For example, "She was murdered by police in what they're calling a "clerical error," this code allows blame for what happened to be deflected (Kaufman, 2020). While not one of the original codes predicted by theory, the occurrence of this afterlife supports Alexander's (2012) assertion that the media centers the perspective of the police.

The larger narratives that emerged to qualify the police's actions that night are as follows:

Breonna Taylor was fatally shot in the March 13 raid as the Louisville Metro Police Department officers tried to execute a search warrant at an alleged drug dealer's residence (Legal Monitor Worldwide, 2020).

Police were allegedly searching the complex for a man who did not reside there (Hall, 2020). 
[T]he 26-year-old EMT was shot to death by Kentucky police officers who raided the wrong home (Vibe, 2020).

Hankison and the other two officers - Jon Mattingly and Myles Cosgrove - were serving the no-knock warrant in a narcotics case involving a suspect who allegedly received packages at Taylor's address years earlier (Dillon, 2020).

[A]n EMT who was killed more than two months ago when three plain-clothes officers serving a no-knock warrant in an attempted drug raid on the wrong apartment shot her eight times (Kaufman, 2020).

serving a no-knock warrant for someone else (Bernucca, 2020).

Taylor has become a symbol of racist police brutality after being fatally shot when police officers burst into her Louisville apartment using a no-knock warrant during a narcotics investigation. The warrant to search her home was in connection with a suspect who did not live there and no drugs were found (Raskin, 2020).

$[\mathrm{H}]$ er murder was a result of a botched drug warrant after cops were believed to be looking for Breonna's ex, Jamarcus Glover (Bird, 2020).

Three Louisville police officers executed a no-knock raid on her apartment in search of a criminal suspect who, as it turned out, had already been arrested (Panetta, 2020).

A search warrant revealed cops believed Glover was hiding drugs or money at Taylor's home. At the time of the raid, Glover was already in police custody 10 miles away. No drugs or cash were found at Taylor's home...the raid was linked to plans to gentrify Taylor's neighborhood. Lawyers say police would 'target' homes on Elliott Ave, where her ex lived, to make way for a real estate project. A warrant was issued for her home to implicate him (MaGee, 2020).

For the purposes of my analysis the "blame" code is not a standalone one, it is viewed here as a subcode of the "failed raid," representing how the narrative of the failed raid evolved to begin questioning itself. This code also tracked narratives that positioned blame for Taylor's death to a specific person(s) or practices. The following excerpts come from the "blame" code: Walker is the man who police say initiated the shootout that caused Taylor's death and sent an officer to the hospital (Legal Monitor Worldwide, 2020).

Sgt. Jonathan Mattingly said Taylor, a 26-year-old emergency medical worker who was roused from her bed by police serving a narcotics warrant, "didn't do anything to deserve a death sentence"...He said he and his fellow officers had gone to Taylor's apartment to 
serve a warrant in a drug case that targeted her ex-boyfriend, and had to defend themselves once they were fired upon (AP Newswire, 2020).

Mattingly admitted the drug raid had gone awry but said he did not believe Breonna was killed 'due to lack of judgment' or 'incompetence' by police. Instead, he blamed Walker and Breonna's convicted drug dealer ex Jamarcus Glover, who was the intended target of the drug investigation (Ruiz, 2020).

Breonna Taylor would be alive if Louisville police had executed a no-knock warrant at her apartment, Sgt. Jonathan Mattingly, one of the officers involved in the botched drug raid (McLaughlin, 2020).

[A] police unit had "deliberately misled" narcotics officers to believe their warrants were focused around dealing with a major drugs hotspot...the five warrants issued on March 12, including on Taylor's apartment, were all part of efforts targeting Glover and others in his building to clear the way for the redevelopment (Jankowicz, 2020).

Within this frame it is interesting to note the misinformation that was disseminated among U.K. based publications specifically MailOnline and The Independent, their reporting included things like:

Louisville police went through with a warrant search on Breonna Taylor's apartment despite it being previously called off... the drug suspect linked with Taylor had been located elsewhere earlier that night, resulting in the end of the need for the warrant... They claim, however, that officers continued to carry out the deadly raid, looking for suspects who had no connection to Taylor (Mulraney, 2020).

In truth, the warrant was not called off, it was merely amended; that amendment was ignored.

The LMPD was aware Glover would not be in the home, but still wanted the warrant on Taylor's home to be executed. Breonna did know Glover, the suspect in question was her ex-boyfriend.

However, some articles broke the mold and corrected the existing failed/botched raid narratives, as seen in the following excerpt:

Jaynes was responsible for falsifying the search warrant application that led to the botched raid Taylor's home last March. He was fired on Tuesday for 'failing to complete a Search Warrant Operations Plan form', CNN reported. Cosgrove was fired for use of deadly force for firing 16 rounds into Taylor's home and failing to activate his body camera (MaGee, 2021). 
Towards the end of the one-year coverage period of this study, the failed raid frame expands to allow exploration of the forces that led to the raid:

The botched raid was linked to a plan to clear out Louisville neighborhoods so a $\$ 30$ million gentrification project could move forward (Mulraney, 2020).

[T] his nation's 50-yearlong so-called War on Drugs, from the faulty premises for the raid in the first place to the ability to enter that home with a "no knock warrant" and a battering ram, triggering the chaos that preceded the killing. We are seeing the ways in which the kind of systemic oppression that ended Taylor's life is inextricably linked to the outrageous dictates of late-stage capitalism, as highlighted in the report that the botched drug raid that killed her was tied to political efforts to clear out her street for a large-scale real estate development (Bunch, 2020).

\section{Afterlife 3: Breonna the Meme}

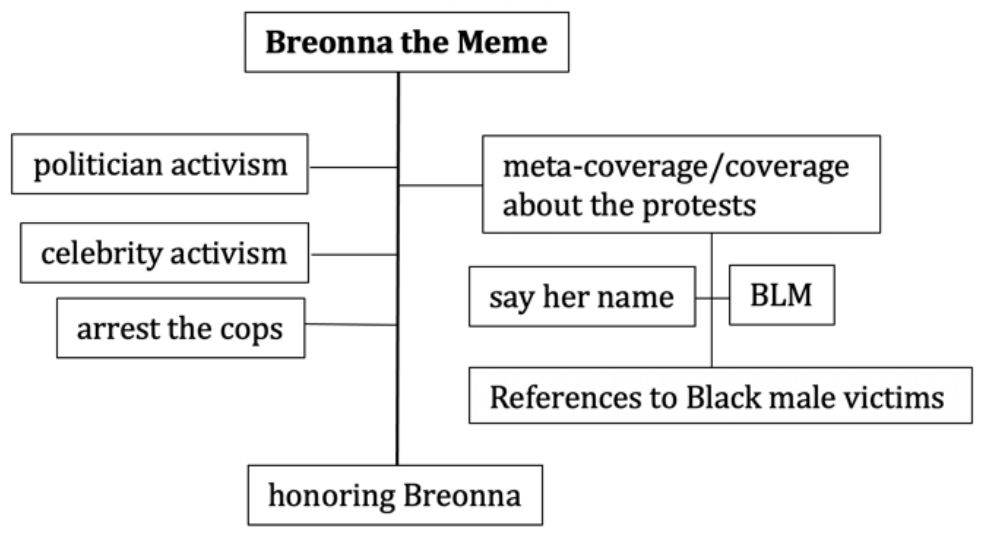

Figure 4. Afterlife 3 Code Tree

This afterlife depicts the many different activism narratives and consists of seven codes: "politician activism," "celebrity activism," "arrest the cops," "meta-coverage/coverage about the protests," "say her name," "BLM," and "honoring Breonna." This narrative afterlife got its name from the biggest, unexpected implication of the \#justice4Bre activism, the memeification of Breonna Taylor. On social media Breonna becomes a meme when the repeated circulation of messages like "arrest the cops who killed Breonna Taylor" and "it's a great day to arrest the cops who killed Breonna Taylor" turn the pursuit of justice into a punchline (Romano, 2020). This 
particular afterlife then, shows us what happens when the only accurate or helpful thing we are disseminating about her online is her name Breonna Taylor. That is, this is the story of how “catchphrases and memes based around Breonna Taylor's name rapidly eclipsed all discussion of the alarming and disturbing circumstances surrounding Taylor's death" (Romano, 2020).

Politician Activism, Celebrity Activism, and "Arrest the Cops." Among the first public figures to demand justice for Breonna were politicians, the first of which came May 14, 2020, from the governor of Kentucky, Breonna's home state. Governor Beshear noted publicly:

Ms. Taylor's death "troubling" and said the public deserved to know everything about the March raid. He asked the state attorney general, the local prosecutor and the federal prosecutor assigned to the region to review the results of the Louisville police's initial investigation "to ensure justice is done at a time when many are concerned that justice is not blind” (Bogel-Burroughs, 2020).

Towards the end of May of 2020, just a few days before the public murder of George Floyd, national politicians including the now Vice President Kamala Harris, began making public justice demands including the following:

Assistant Attorney General Eric S. Dreiband launch an independent investigation into the killing of Breonna Taylor, and into whether the Louisville Police Department has engaged in a pattern or practice of constitutional violations (Congressional Documents and Publications, 2020).

These initial acts of public activism did not lend themselves to bringing Breonna to national attention, it was not until major celebrities took up the mantle of justice that we began to say the name Breonna Taylor. The first week of June 2020, saw a sharp increase in Google searches for "Breonna Taylor," after a celebrity awareness campaign launched in celebration of what should have been Breonna's $27^{\text {th }}$ birthday (Romano, 2020). The "arrest the cops" slogan launched by celebrities, the most prolific being professional athletes, musicians, and Oprah "became a clarion call, divorced from Taylor's life and image — the newest virtue signal of choice" (Romano, 2020). Headlines during this time included: 
Solange, Demi Lovato, Lizzo, Selena Gomez \& More Demand Justice For Breonna Taylor on Her Birthday (Kaufman, 2020).

Alicia Keys Leads All-Star Call for Justice for Breonna Taylor in Powerful PSA (Mamo, 2020).

Beyonce Demands 'Justice' for Breonna Taylor on Her 27th Birthday (Aniftos, 2020).

Demi Lovato Encourages Fans to Send Cards to Kentucky Attorney General on Breonna Taylor's Birthday (Kaufman, 2020).

While Hollywood superstars made social media statements like those depicted above, professional athletes took on a more physical and performative tact to bring awareness and justice for Breonna as illustrated in the following excerpts:

WNBA players announced they would pay homage to women who have been killed by police and in episodes of racial violence (Amatulli, 2020).

US Open Day 1: Naomi Osaka wears 'Breonna Taylor' face mask (The National, 2020).

LeBron James and the Los Angeles Lakers are licking their wounds after Tuesday's playoff loss against the Portland Trail Blazers, the team also managed to cause a stir with hats the players wore that demanded justice for Breonna Taylor before the game. At first glance, the red hats might appear to be MAGA hats used to support President Donald Trump, but they read 'Make America Great Again Arrest The Cops Who Killed Breonna Taylor.' (International Business Times News, 2020).

When Oprah began her campaign of justice for Breonna, it received wide public and media attention including the following coverage:

Oprah Winfrey gave up her usual place on the cover of O magazine to Breonna Taylor (London Free Press, 2020).

Oprah Winfrey demands justice for Breonna Taylor in series of Louisville billboard buys (Perano, 2020).

Oprah Winfrey Demands Justice For Breonna Taylor With 26 Kentucky Billboards (Amatulli, 2020).

Oprah Winfrey puts her Breonna Taylor O Magazine cover on 26 BILLBOARDS across Louisville (Stern, 2020). 
As time continued celebrity activism brought forth a merchandise as their activism began to center around props. This ultra-performative appeal to justice focused on the following kinds of actions:

Celebrities Wear 'Arrest The Cops Who Killed Breonna Taylor' Shirts To Raise Awareness (International Business Times, 2020).

Stranger Things actress Priah Ferguson wrote 'we got you Miss Breonna,' alongside a photo in the shirt. Other celebrities who shared photos for the campaign include Ruby Rose, Sarah Paulson, Regina King, Nikki Reed and Diane Guerrero (Chudzinski, 2020).

Once celebrities began posting photos of them in regalia dedicated to achieving justice for Breonna, everyday people took up the mantle of the "arrest the cops" campaign as well with the effect of:

For profit merchandise exploiting Taylor's name...one store sold Breonna Taylor and BLM face masks alongside Blue Lives Matter masks without any acknowledgment of their ideological contradictions (Romano, 2020).

The internet can take the words and experiences of Black people and turn them into a static form of emotional currency... This phenomena is known as digital [B]lackface...the pain and suffering of a Black woman is given backseat to the humor people extract from their circumstances (Coco, 2020).

Instead of making people more aware of what's happening, they're oversaturating people's timelines...leading to people being desensitized to something so heinous...we need to treat Breonna Taylor's death with the same respect that we treat [B]lack men who have been victims of police brutality (Holiner, n.d.).

We haven't seen this kind of memeification when it comes to [B]lack men who are victims of police brutality, only women. We need to ask ourselves why that is. Is it because we take the death of [B]lack women less seriously?" (Holiner, n.d.).

Say Her Name, BLM, and References to Black Male Victims. The Say Her Name and BLM activism emerged following the success of the celebrity led "arrest the cops" campaign. Within the "Say Her Name" code I tracked 14 mentions of the names of other Black women victims of police brutality, comparatively, there were 218 mentions of the names of Black male 
victims of police brutality. This massive disparity in coverage really underscores and supports the need of a campaign like Say Her Name (Crenshaw, et al., 2015; Ritchie, 2018). This code develops this idea further including the reporting that explicitly states:

The \#sayhername hashtag has been corrupted and co-opted to include everyone else but the people it was originally intended for (Coco, 2020).

Even the hashtag \#SayHerName itself was subsequently overlooked after its initial creation, as it became co-opted into broader ongoing social media trends like \#SayHisName and \#SayTheirNames" (Romano, 2020).

Perhaps stories about her killing were lost in the noise of a world seemingly collapsing. Or perhaps we are conditioned to de-prioritize the brutality faced by Black women in America (Hubbard, 2021).

The "BLM" code is composed of narratives that seek to legitimate why people are protesting against police brutality and to qualify why people have chosen to participate. Unlike the "Say Her Name" code, these narratives feature Breonna Taylor and what happened to her but they do not center her. Excerpts that characterize this code are as follows:

The lives of George Floyd, Ahmaud Arbery, Tony McDade, Breonna Taylor and so many more mattered. Black lives matter (Better Georgia, 2020).

Taylor's death prompted major protests during a moment of heightened racial tensions across the country, in part sparked by the numerous police-shootings of black people that have been witnessed in videos that drew national media attention throughout the summer (Riotta, 2020).

Honoring Breonna. This code explores the narratives of why people have expressed a need to engage in activism to ensure that there is justice for the death of Breonna Taylor. This micro narrative began with the celebrity birthday campaign as expressed here:

Today is Breonna Taylor's birthday. To truly honor her, we can't just pursue the cops who shot her; Reform or a handful of prosecutions isn't the answer to Breonna Taylor's death it's nowhere near enough (Gagliardo-Silver, 2020).

These narratives show that in honoring Breonna through the appropriate handling of her murder through the justice system, society could be altered in the following ways: 
[T] he power and the responsibility to bring justice to Breonna Taylor, [would] demonstrate the value of a Black woman's life [in the eyes of the justice system] (Iasimone, 2020).

Outraged at the atrocity of the officers' actions, the people of Louisville, and eventually the rest of the country, took to the streets to protest in her honor (Young, 2020).

Oprah writes of the decision to replace herself on the cover of O magazine that:

“'Breonna Taylor had plans. Breonna Taylor had dreams,' she wrote. 'They all died with her the night five bullets shattered her body and her future" (Stern, 2020).

What I know for sure: We can't be silent. We have to use whatever megaphone we have to cry for justice... Breonna Taylor deserves so much more than the cover of a magazine. She deserves to be alive as do so many others killed at the hands of the police (Leishman, 2020).

Honoring Breonna appears to be society's consolation for her no longer being alive.

\section{Afterlife 4: \#(In)Justice for Breonna: Breonna the Victim of Injustice}

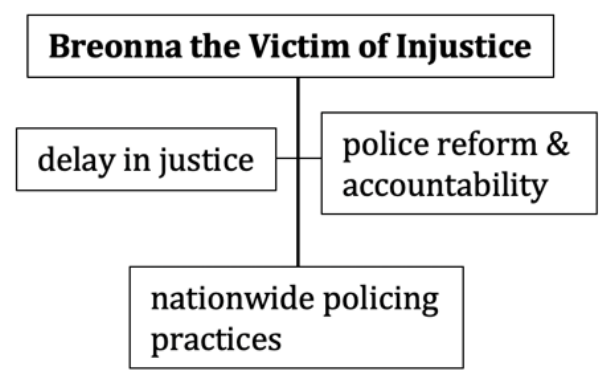

Figure 5. Afterlife 4 Code Tree

This afterlife focuses on the elusiveness of justice for Breonna, how the justice system offers refuge to the officers who killed her rather than hold them accountable. It consists of three different codes: "delay in justice," "police reform \& accountability," and "nationwide policing practices." Depicted here is the beginning of news reporting that examines the United States' justice system through the framework of Breonna Taylor's life and death. The "delay in justice" code is the smallest of this afterlife; it orients the reader to the passage of time from Breonna's murder to the present moment in which the article was written. This code serves as an introduction to the (in)justice that was served. It depicts the following ideas: 
'Three months have passed - and zero arrests have been made, and no officers have been fired.' 'Three months have passed - and Breonna Taylor's family still waits for justice. Ms. Taylor's family has not been able to take time to process and grieve. Instead, they have been working tirelessly to rally the support of friends, their community, and the country,' Beyoncé said (Iasimone, 2020).

We are seeing the total rot that has corrupted the political system of Kentucky, where it took three months for local police brass to finally fire the unrestrained shooter Hankison ... Nor did Hankison's long-overdue firing explain why he still had a badge, after years of allegations of both sexual and official misconduct (Bunch, 2020).

Where is the idea of 'justice' when it has been nearly five months, and still, the police who shot Breonna Taylor walk free? (Leishman, 2020).

Daniel Cameron, the attorney general of Kentucky who is now in charge of the case, had time to speak at the Republican National Convention last week, but he has not found the time to bring to justice the three cops who shot Taylor in her own apartment. What have the authorities been doing for the past five and a half months? (Mystal, 2020).

Police reform \& Accountability. Following the questioning of the timeliness of justice, those covering the developments in the Breonna Taylor case began discussion of the lukewarm initial moves the state took in holding its officers accountable. Early excerpts from this code are as follows:

F.B.I. to Investigate Shooting of Breonna Taylor by Louisville Police (Gross, 2020).

Louisville bans 'no-knocks' after Breonna Taylor's death (Lovan, 2020).

[O]pening an internal investigation into the shooting and had placed the three involved officers on administrative leave (Targeted News Service, 2020).

A Kentucky prosecutor is moving to dismiss an attempted murder charge against the boyfriend of Breonna Taylor, who shot a police officer as they entered Taylor's home... Louisville's police chief announced his retirement and the mayor changed some police warrant search policies (Lovan, 2020).

One of the three police officers involved in the fatal shooting of Breonna Taylor is being terminated for "blindly" firing 10 rounds into her apartment (Dillon, 2020).

Louisville May Become Latest City to Declare Racism a Public Health Crisis... One Louisville officer was terminated in June; two other officers have been placed on administrative reassignment (Paybarah, 2020). 
'The FBI and a special Kentucky prosecutor are investigating Breonna's killing and whether charges can be brought against the officers' (Salon, 2020).

(LMPD) major who oversaw officers involved in the March 13 shooting death of 26year-old Black woman Breonna Taylor, has been demoted to lieutenant after allegedly defying an order from her commanding officer not to question departmental investigators looking into her department's behavior in the raid that led to Taylor's death (Villarreal, 2021).

Many reform measures have already [been] taken, the mayor said. They include Breonna's Law, which bans no-knock warrants and mandates the use of body cameras for officers serving search warrants. It also encourages officers to volunteer in the neighborhoods they serve (Kallingal \& Romine, 2021).

Some articles break from a stance of neutrality and position the reader to be disillusioned

with the state of our justice system like the following article:

Breonna was denied the ability to turn 27 because a police force that plays judge, jury, and executioner with black bodies pumped eight bullets into her when they broke into her home with no warning during a failed drug sting.

Had the police not opened fire when they broke down the door, then maybe she would be planning on meeting her friends at a bar, just like you would (Gagliardo-Silver, 2020).

Nationwide Policing Practices. This code takes a deeper look into policing

practices/policies on a national rather than local level. It includes the subsequent quote:

'As Prison Industrial Complex (PIC) abolitionists, we want far more than what the system that killed Breonna Taylor can offer - because the system that killed her is not set up to provide justice for her family and loved ones...

Since 2005 there have only been 110 prosecutions of police officers who shot people, while police have killed 1000 people a year on average since $2014 \ldots$

police officers who use excessive force are given every benefit of the doubt in the U.S., many African-Americans are guilty until proven innocent under the country's criminal justice system...

if past experience is any indicator -the law will once again provide [the police] with cover for killing another black person. Meanwhile, countless black women and trans people who act in self-defense when police fail to protect them languish in prison.' (Salon, 2020). 


\section{Afterlife 5: Breonna the Catalyst of Retaliatory Violence}

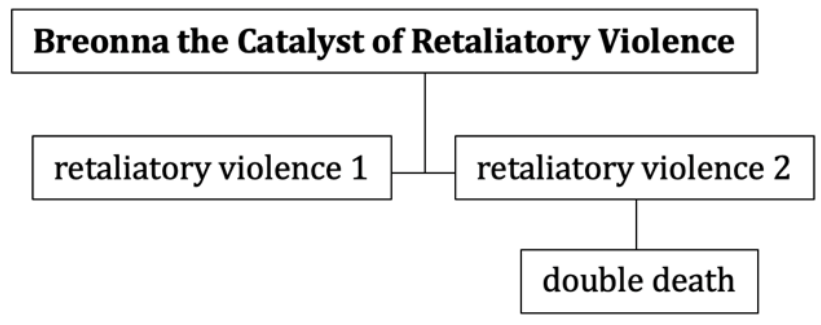

Figure 6. Afterlife 5 Code Tree

This afterlife was perhaps the most interesting, it consisted of two main codes:

"retaliatory violence" and "double death." This afterlife took several unexpected turns, and as such the retaliatory violence code was split into two parts. The original story this afterlife set out to track was based on my theoretical assumptions within my second hypothesis (H2) which postulated that some reporting would attempt to link the protests to a spike in violence against police officers. As time went on this afterlife proved to depict a narrative battle in the media.

Retaliatory Violence I. The first micro narrative of this code was in keeping with $\mathrm{H} 2$, it focused on protest violence and tense demonstrations in the city like the following:

Seven people were shot Thursday night, with one in critical condition, during a protest in Louisville, Kentucky over the death of Breonna Taylor (Hansen, 2020).

Shooting rampage in US as 'gunman opens fire' at protest crowd over death of black woman (Mcfadden, 2020).

Breonna Taylor decision: two officers shot in Louisville as protests erupt across US... A riot was declare[d] in Portland, Oregon, where police shared a video which appeared to show them being attacked with a Molotov cocktail (Belam, 2020).

Anger continues to simmer across the country as no officers have been charged in Taylor's death despite national protests and demands for charges (Tanno, 2020).

Kentucky man accused of shooting two police officers during demonstrations over the killing of Breonna Taylor has been indicted on 35 charges... after a grand jury process led by State Attorney General Daniel Cameron produced no charges involving the shooting of Taylor by police (AP news wire, 2020). 
Retaliatory Violence II. As time went on the code moved on physical violence to political/legal violence. Around October comes a major shift to almost exclusively covering political/epistemic retaliatory violence of the involved police officers. After Kenny Walker files a lawsuit against the city of Louisville and the LMPD about the terrible way he was treated at every step, officer Mattingly, who was shot in the leg during the raid, filed a counter lawsuit against Walker this narrative is shown here:

The officer's lawsuit states the incident caused Mattingly 'severe trauma, mental anguish, and emotional distress'. 'Walker's conduct in shooting Mattingly is outrageous, intolerable, and offends all accepted standards of decency and morality,' the suit reads (Kenton, 2020).

As a white man, Mattingly uses the legal system to attempt to punish a Black man, because the retaliation is not a form of physical violence, it is viewed as more legitimate retaliation. None of the articles break from neutrality in covering this event, none position the reader to think our legal system is flawed for allowing a police officer to sue a civilian for exercising their right to self-defense.

This narrative of retaliatory violence is further developed through coverage of other public officials reacting to public appeals for justice for Breonna. It constitutes both political and rhetorical responsive violence seen here through the following coverage:

The sheriff in charge of protecting the Tampa Bay Rays has said he may withdraw his officers from their work with the baseball team, after he was angered by a tweet which called for the arrest of Kentucky officers who killed Breonna Taylor (Alexander, 2020).

We see that the police are more concerned with self-preservation than justice and preserving public order. The murder of a young woman is a fact, yet it is highly politicized here because she was a Black woman. The police, public servants, think they can just collect their taxpayer funded paychecks while only serving those they want to or choose to serve. 
Also angered by the publicity and attention given to Breonna Taylor's murder was a

Georgia school teacher. In response to a school morning announcement statement made about

Breonna she responded to her students accordingly:

'Dr. G is on the announcements reading about, what's her name, Breonna something?

The one who was killed in the gunfire from the cops,' McCoy began. 'I'm sorry she was

killed, but you know, when you hang out with people with guns who shoot at cops, you're likely to get caught in the crossfire.'

'You know, if you hang out with people who are criminals and they shoot at a cop you're likely to get caught in the crossfire, it does not matter what color your skin is, you're likely to get caught in the crossfire,' McCoy repeated. 'I'm really truly I'm, it's sad that she put herself in that position but she put herself in that position by hanging out with somebody she shouldn't have been with' (Fieldstadt, 2021).

The teacher in question was under investigation by the school district following the incident.

Double Death. The above excerpts lead directly to the next code "double death" which

focuses on the character interrogation and assassination of Black victims. This code, however, differs from the last in that it centers state moves to blame Breonna for her own murder rather than the perspectives of individuals. The following statement made by Breonna's boyfriend Kenneth Walker's attorney best characterizes the theme of this code:

We believe the city used Kenneth as a pawn to cover up the events that took place on March 13, 2020, and further used him to cover up the deep-seated failures within the Louisville Metro Police Department.' 'It does not go unnoticed that neither the city nor the LMPD has apologized for using Kenneth as a scapegoat for an improper raid gone bad,' he added (Better Georgia, 2021).

The following statement was made by the attorney for Taylor's family:

Prosecutors tried to get Breonna Taylor's ex-boyfriend Jamarcus Glover to say that Breonna Taylor was part of an 'organized crime syndicate' in exchange for a plea deal...It's enormously ironic that the accused drug dealer here acted with honor, refusing to falsely discredit Bre after her death...

while prosecutors and police acted in the most egregiously dishonest and dishonorable way possible. The police killed Bre once, and now they're trying to kill her again by killing her reputation and her good name' (Better Georgia, 2020). 
This final statement exemplifies how the media understands the actions of the state in the aftermath of Breonna's murder:

The authorities have been busy harassing the Black men who knew Taylor, while trying to name Taylor, posthumously, as a criminal defendant. Instead of building a case against the police officers who killed her, it would appear that Kentucky prosecutors have been doing everything they can to build a case against Taylor, in a desperate yet classic[1] attempt to blame a Black person for 'forcing' the cops to kill them (Mystal, 2020).

\section{Afterlife 6: Breonna the Victim of Performative Justice}

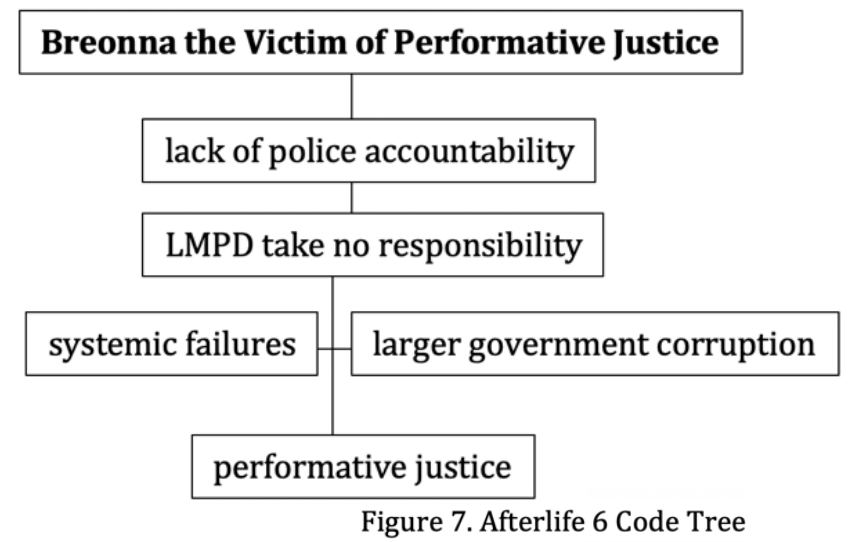

This afterlife tells the stories that were presented in media on the lack of direct material consequences for the murder of Breonna Taylor. It consists of five codes: "lack of police accountability," "LMPD take no responsibility," "systemic failures," "larger government corruption," and "performative justice." This afterlife is best understood through this quote: "With every death of a Black person at the hands of the police, there are two real tragedies: the death itself and the inaction and delays that follow it" (Iasimone, 2020). The performative justice afterlife is a play on the phrase performative activism, defined as white ally "activism" that serves more as self-promotion and virtue signaling for the purpose of "receiving some kind of reward — on social media, it's that virtual pat on the back for being a 'good person' or 'on the right side"” (Metta, 2020; Phillips, 2020). Performative justice then, are moves made by the state and state actors that effectively serve more as good public relations rather than a commitment to 
fulfilling public pleas and demands for justice for Breonna. This afterlife looks at media reporting that illuminates the causes and effects of these kinds of state actions.

Lack of Police Accountability and LMPD Take No Responsibility. This code tracked reports of how the police sidestepped responsibility for killing Breonna. The following selections highlight the LMPD's lack of transparency:

'Each step of the way since this tragic killing, Ms. Taylor's family and the public has had to demand action from their state and local leaders to learn what happened on the night of the killing and to seek justice for Ms. Taylor. They have been disappointed at every turn' (Targeted News Service, 2020).

Cops released 'blank' report saying [Breonna] suffered 'NO' injuries on night she was shot eight times and killed by cops (Kenton, 2020).

The incident report also consists of many falsities and incorrect claims, such as listing Taylor's injuries as "none", even though she was shot eight times before bleeding to death. It also stated that the officers did not force their way into the apartment, even though a battering ram was used on the front door to break it open (Young, 2020).

For weeks, the city treated Breonna like she was a criminal, calling her a "suspect" before finally admitting that she was an innocent, crimeless victim (Panetta, 2020).

A "lack of transparency" from police after the team's open records requests were denied..."This administration simply believes it is above the law," (Roos, 2020).

These frames have affected public opinion in the following way:

It is impossible to summon any respect for any law enforcement in the United States remembering that Jonathan Mattingly and Myles Cosgrove are still going to work in their blue uniforms (Bunch, 2020).

Systemic Failures. This code looks at micro narratives on the LMPD's actions and policies that uniquely engendered an environment that almost ensured Breonna would not have survived the raid that night. This code began with narratives that sought to uncover what really went wrong on the night of the raid. It interrogated the LMPD's actions that night and how they compared to department policy. Some framing under this logic include: 
An ambulance that had been stationed near Taylor's apartment in anticipation of the initial search had been called off, the suit said. It said the EMS unit was cleared because police 'had never actually intended to raid Breonna's home unless (Glover) was there'... Taylor lived for another five or six minutes after she was shot but an ambulance was not on the scene (Mulraney, 2020).

An ambulance on standby outside the apartment was told to leave an estimated hour before the raid, completely contradicting standard police protocol (Toua, 2020).

The Courier-Journal reported that for more than 20 minutes Ms Taylor laid where she collapsed in her hallway until around 1.10am and wasn't given any medical assistance (Randall, 2020).

'In the six minutes that elapsed from the time Breonna was shot, to the time she died, we have no evidence suggesting that any officer made entry in an attempt to check and assist her' (MaGee, 2020).

Following this frame comes narratives explicating a series of harmful LMPD practices

that laid the ground for the raid that resulted in Breonna's murder as shown here:

In the past two years, before the city banned them in June, Louisville Metro Police Department officers received court approval for at least 27 no-knock warrants... for 22 of those warrants, $82 \%$ of the listed suspects were Black and $68 \%$ were for addresses in the West End, a section of Louisville with predominantly Black neighborhoods (Mencarini, Costello \& Duvall, 2020).

Jaynes violated department procedures for preparation of a search warrant and truthfulness. Jaynes acknowledged in a May interview with Louisville police investigators that he didn't personally verify that a drug trafficking suspect, Jamarcus Glover, was receiving mail at Taylor's apartment (AP Newswire, 2021).

Larger Government Corruption. This code follows micro narratives that the state deliberately took actions that prevented Breonna's family and other loved ones from achieving justice. It is composed of articulations like these:

The attorneys for Breonna Taylor's family this week accused Louisville Mayor Greg Fischer and the Louisville Metro Police Department of covering up information in the investigation into Taylor's death, which allegedly resulted in delays in the case...police "unlawfully denied several open records requests" and alleged the mayor's administration has been "the least transparent, the slowest and the most frustrating" of all U.S. cities in its handling of recent police violence involving black Americans (Roos, 2020).

A connection between gentrification programs and brutal police tactics 'wouldn't be uncommon' ...'Cities often use police to pursue redevelopment ends and gentrification 
often coincides with increased policing,' he said in an interview. 'So if this were the case in Louisville, it would hardly be unique. So I wasn't surprised [by the lawsuit], but of course ... it's a shame that cities are still using arrest tactics, especially for... drug crimes to pursue redevelopment,' especially in a case that apparently cost an innocent person her life (Salon, 2020).

Performative Justice. This code depicts the largely empty and symbolic instances of justice/accountability efforts initiated by the state made to placate those calling for justice. This code is largely framed around the actions of the Louisville mayor's office, Attorney General Cameron and the Grand Jury process. Then President Trump made the following empty virtue signaling condolence to Taylor's family:

Donald Trump offered his condolences to Ms Palmer and her family. "I think it's a sad thing and I give my regards to the family of Breonna. I also think it's so sad what is happening, everything about that case including law enforcement," the president said. "So many people suffering, so many people needlessly suffering. But with respect to Breonna, we give our regards to her family" (Buncombe, 2020).

Trump name drops Breonna for attention and to broaden his platform and audience only to make clear that his administration stands on the side of law enforcement.

Most central to this discussion are the actions of Kentucky Attorney-General Daniel Cameron, an overview of the controversies are shown here:

[Cameron] announced the results of the grand jury investigation last month. At that announcement, he said prosecutors 'walked the grand jury through every homicide offence'... He also said "the grand jury agreed" that the officers who shot Ms. Taylor were justified in returning fire after they were shot at by Mr. Walker (ABC Premium News (Australia), 2020).

Soon after this statement was made several of the grand jurors responded by filing a lawsuit that would allow them to share their experiences of being on the grand jury and its proceedings to the public, and the request was granted. We see the performative justice of the state being countered by concrete change and justice initiated by the people through these narratives:

Jurors were rankled by Cameron's statements after the proceedings, including that grand jurors "agreed" that no other charges were justified. "I felt like he was trying to throw the 
blame on somebody else, that he felt like, we as jurors, we weren't going to (speak) out," she said. "He made it feel like it was all our fault, and it wasn't" (AP Newswire, 2020).

'Our review of the grand jury proceedings reveals that Kentucky Attorney General Daniel Cameron's team presented evidence in a biased manner that protected the involved officers rather than hold them accountable' (Targeted News Service, 2020).

Prosecutors from the Kentucky attorney general's office never presented grand jurors with the option to consider indicting officers on more serious charges for Taylor's death (Jack, 2020).

Three grand jurors in the Breonna Taylor case filed a petition with the state House of Representatives, calling for the impeachment of Attorney General Daniel Cameron for mischaracterizing their findings and presenting bs to the media to make himself look better... Cameron failed in his duties and breached public trust for his handling of the big case (Jack, 2021).

Following being called out by members of Breonna's grand jury Cameron attempted to

remedy his image by presenting more symbolic justice shown here:

Kentucky's attorney general has formed a task force to study the search warrant process nearly a year after the fatal shooting of Breonna Taylor...The warrant used at Taylor's home and how it was obtained was not part of Cameron's investigation... The task force will consist of the chairs of the Kentucky Senate and House judiciary committees; two representatives appointed by the Chief Justice of Kentucky's Supreme Court; several police members; a member of the Kentucky NAACP and three citizen appointments. It will be chaired by the attorney general's office (AP news wire, 2021).

This announcement highlights how empty justice is when the victim is a Black woman. The chair of this task force is the same entity that failed to even present murder charges for her death or evidence that was not completely biased in favor of the officers, meaning the same false promise of justice is likely to repeat itself. Mignolo $(2009,2011)$ supports the emptiness of this action through the articulation that the institutions responsible for injustices are perpetually going to be incapable of solving the problems they engendered.

The city of Louisville and the LMPD also tried to make themselves look better in light of the controversy and outrage following an unproductive grand jury proceeding. In the ten months following Breonna's murder, with the underscoring of department failures presented in the media 
and by activists, the LMPD went through four police chiefs in an attempt to distance itself from its controversies, symbolically attempting to position the people into believing that a new era of LMPD practices and leadership has been brought forth. I will illustrate this through the coverage of the new police chief eras. Of the interim chiefs is Black woman Yvette Gentry who was appointed around the time of the grand jury, her positionality is meant to placate us into believing that finally there will be someone in police leadership who cares about serving justice for Breonna. Gentry is credited with the following moves towards justice:

Officer Myles Cosgrove and Det. Joshua Jaynes received notice last week from Louisville Police interim Chief Yvette Gentry that she intends to dismiss them from the department (AP Newswire, 2021).

Louisville Police Department fires cop who shot Breonna Taylor dead and officer who obtained no-knock warrant that led to botched raid (Ruiz, 2021).

(LMPD) major who oversaw officers involved in the March 13 shooting death of 26year-old Black woman Breonna Taylor, has been demoted to lieutenant after allegedly defying an order from her commanding officer not to question departmental investigators looking into her department's behavior in the raid that led to Taylor's death (Villarreal, 2021).

The appointment of the new permanent chief emphasizes just how hollow police reform

is through the following statements:

Police Chief Who Resigned After Fatal Shooting Will Lead Louisville Department (headline)

Shields comes to a city that is still dealing with an even more prominent police shooting than the one she had to deal with in Atlanta - that of Ms. Taylor...

qualified chiefs with progressive views, including Ms. Shields, have been sidelined after high-profile incidents of police violence, often sacrificed by elected officials looking for political cover...

Martin, the political activist, said she was disappointed that officials appointed Ms.

Shields, who was asked to resign by the Atlanta chapter of the N.A.A.C.P. following the killing of Mr. Brooks...Ms. Shields "can expect activists from Atlanta to be in Louisville — we want to hold her accountable." (Wright, 2021).

Louisville has hired Atlanta's former chief to lead its police department after months of unrest over the fatal shooting of Breonna Taylor, and fired two more officers involved in the deadly raid (Tampa Bay Times, 2021). 
The above excerpts show the issues associated with the newest Louisville Metro PD chief.

Shields was asked to resign following a fatal and unnecessary police shooting of a Black man at her last department, in order to allow the city of Atlanta to heal from her mismanagement of the department. So why then does Louisville think the answer to their issues with an even higher profile police shooting of a Black person is Chief Shields? Under this frame, it is clear that police chiefs get reshuffled throughout other problematic departments as part of empty in-name-only political maneuvering.

Some public reactions to the symbolic nature of justice in the Breonna Taylor case are as follows:

The prosecutors in Kentucky have one goal: to secure an acquittal for the police officers who shot Taylor should public pressure somehow force them to bring charges against those officers (Mystal, 2020).

Activists and racial justice campaigners reacted with anger on Wednesday after a grand jury revealed that only one police officer involved in the killing of Breonna Taylor would face charges, and none of those charges relate to her death..."It does not address her being a victim of being killed. The value of her life is not at all addressed. When we say Black Lives Matter, this indictment says it does not matter" (Hall, 2020).

The way in which grand juries have been deployed, the way in which the district attorney and the police handled this from the very beginning, sends a very powerful message about the different tiers of justice we have in this country and how the system is not broken, but in so many ways is operating exactly the way it was designed... The system worked to protect the police officers but not the citizens that police officers are supposed to serve. The people of Louisville deserve better and Black people in that town deserve better (Targeted News Service, 2020).

\section{Afterlife 7: Breonna the Inspiration of Change}

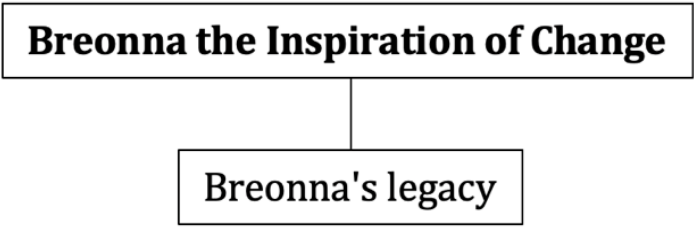

Figure 8. Afterlife 7 Code Tree 
This final afterlife leads us through an exploration of how Breonna's murder has permanently altered society. In the wake of her death she has become an American symbol, "Breonna is bigger than Breonna" (Sloan, 2020). This afterlife sought to capture in order to chronicle how Breonna Taylor became the Say Her Name campaign's first major crossover icon, becoming the first Black woman martyr of the Black Lives Matter movement. To reiterate the words of her mother Tameka Palmer: "I hate that she had to die to be great" (Sloan, 2020). While only encompassing one code "Breonna's legacy," this narrative afterlife takes Ms. Palmer's quotation in mind, by exploring the greatness that was inspired in the direct wake of Breonna's death.

Perhaps the most significant of Breonna's legacies is that she made activists out of us all. The horrifying circumstances of what the state perpetrated against Breonna leading to and following her death inspired millions of people to take on the mantle of affecting institutional changes. The foremost activists to emerge after Breonna's murder, was her family, specifically her mother and sister, who took on the task of justice for all as a coping mechanism because the lack of justice in her case did not allow them the closure to fully process their grief as shown here:

Breonna Taylor's mom described her relentless grief on the five-month anniversary of her daughter's death Thursday and gave new details of her first meeting with Kentucky's top prosecutor. "One hundred and fifty days. Five months. Yeah. Every day is still March 13," Tamika Palmer said wearily as she stood outside Louisville City Hall. "There definitely shouldn't be another Breonna Taylor, anywhere. It's definitely bigger than Breonna. Five months. I'm grateful to everybody. I'm grateful for people who are saying her name" (Dillon, 2020).

In the months since the 26-year-old woman was killed by three Louisville police officers in March, Breonna Taylor's mother Tamika Palmer, has tried to both seek justice for her slain child, and be an anchor for her daughter, Juniyah, who is 20. "She's had to become this activist, this person who's fighting constantly against the world. It's sad because she 
doesn't get to be her 20-year-old-self. I feel a little of who she may have wanted to be has become lost in this," she said...Ms Palmer said she wanted to use the tragedy to force action and to prevent it happening to others, especially people of colour. Also, at the front of her mind, is the desire to protect her other child (Buncombe, 2020).

Ms. Palmer's afterlife following the death of her oldest child is seen to be one of an advocate, a public speaker, and a philanthropist. Cardi B's Woman of the Year award at the 2020 Billboard Women in Music event was by Breonna's mother Tamika Palmer, a platform that allowed greater visibility and prominence to what happened to her daughter (Atkinson, 2020). Ms. Palmer was also a speaker at the Hudson County Community College Speaker Series Event (US Fed News, 2021). In addition to public appearances she created The Breonna Taylor Foundation with the objective to:

Support economic, social, and racial justice through police reform and government accountability. The foundation also seeks to help young people to realize their full potential, empowering them to participate in political processes and achieve better health, with mentorship programs for high-school girls, after-school initiatives, and educational support (Iasimone, 2021).

Not all justice moves from state actors were performative, Breonna's legacy included changing hundreds of years of legal precedent that previously ensured the grand jury process be as secretive as possible. After the outrage that none of the three officers would be indicted for murder material moves to changing the structures and practices of policing and the legal system did happen such as the following:

[In December of 2020] Virginia lawmakers passed a host of police and criminal justice reforms, including a ban on the use of chokeholds, a requirement that officers intervene to stop the use of excessive force by another officer, and changes that make it easier to decertify officers who commit misconduct. 'We're here today because when the country saw what happened in March, people said that's wrong, you need to do something,' Gov. Northam said of Taylor's killing (AP Newswire, 2020).

Arizona OK's 'Justice for Breonna Taylor' Law Banning No-Knock Warrants, and More (Greenwald, 2021). 
A new bill under consideration in the Utah Legislature seeks to rein in the use of controversial "no-knock" warrants that allow police to burst into someone's home without warning in order to make an arrest or search for evidence of crimes...[it] The bill would mandate that a supervisory official review a search warrant affidavit, perform a "risk assessment" of the circumstances, ensure "reasonable intelligence-gathering efforts have been made" and then determine whether it's time for a warrant or if the officer should consider gathering more information (Stevens, 2021).

Taylor's death brought to light the use of such raids, and 'place-based' policing strategies[9] that targeted areas being gentrified by the city. [Legislators state that]'As the state that created no-knock warrants, Wisconsin has the responsibility to be the state to end their use (Holmes, 2021).

The courts changed shape for the following reasons:

Members of the grand jury panel were given the green light to speak publicly under a Monday ruling from Jefferson Circuit Court Judge Annie O'Connell.

In the same ruling, O'Connell ordered the release of grand jury records, citing the need to show if 'publicly elected officials are being honest'.

'This is a rare and extraordinary example of a case where, at the time this motion is made, the historical reasons for preserving grand jury secrecy are null,' O'Connell wrote in the ruling. O'Connell said she made her decision after considering 'the interest of citizens of the Commonwealth of Kentucky to be assured that its publicly elected officials are being honest in their representations' (Ruiz, 2020).

"This is a rare and extraordinary example of a case where, at the time this motion is made, the historical reasons for preserving grand jury secrecy are null," Jefferson Circuit Court Judge Annie O'Connell wrote in the ruling (AP Newswire, 2020).

The activism stemming from the grand jurors were qualified in the following ways:

The grand jurors did not choose this battle,' Kevin Glogower, the attorney representing the jurors, said in a statement Friday. 'This battle chose them. These are randomly selected citizens who were compelled to sit on a grand jury and were terribly misused by the most powerful law enforcement official in Kentucky' (Ruiz, 2021).

The grand juror said she decided to talk in part because she wanted Palmer to know 'we didn't have anything to do with' the lack of charges on the officers who shot Taylor. "I didn't feel that the family was getting justice,' she said (AP Newswire, 2020).

Breonna Taylor Grand Jurors Lodged Petition To Prosecute Attorney General Daniel Cameron (Legal Monitor Worldwide, 2021).

Through Breonna Taylor, the state directly and indirectly victimized and traumatized so many people, myself included, in a way that was so unsustainable we were left with no choice but to 
speak up for her, to fight for her. By July of 2020, four months after her murder online activism in her name broke records, the "Change.org petition demanding accountability for the death of Breonna Taylor [had] surpassed 10 million signatures;" becoming the second most signed in the site's history (Panetta, 2020). The outdoor memorial for Breonna located in the downtown Louisville park that served as the rallying point of protests was moved indoors to a Black history museum. So that she could be forever remembered and honored as the victim of police brutality who inspired the world to speak up (AP Newswire, 2020). The following quotes speak to why everyday people have chosen to rally behind Breonna:

Six months literally since Breonna Taylor was gunned down in her own home, we've seen that a community has risen up...part of changing the world and part of that change is exposing all of the things, all of the laws, all of the structures, all of the systems that stand in the way of equality and justice and freedom. So while we are not getting the verdicts that our community needs and deserves right now, I am hopeful about both the ongoing protests and advocacy movements and the potential for achieving real change (Targeted News Service, 2020).

Camille Bascus, a 50-year-old black woman, traveled more than 400 miles from Atlanta to Louisville 'to represent the people without voices, because they no longer have a heartbeat. We have a voice and our lives matter' (Schrader, 2021).

The public pressure and attention to the Breonna Taylor case also brought with it the following unexpected consequences:

[There is now extremely] low morale in the LMPD. An internal survey conducted in the summer of 2020 showed that approximately $75 \%$ of respondents said that if they had a chance to leave and move to another agency, they would... In addition, the department is having issues recruiting and retaining new staff (Kallingal \& Romine, 2021).

In addition to several separate calls to impeach and or prosecute AG Cameron, he is haunted by Breonna's memory in other smaller ways as well. Media framing of Cameron now characterizes him as "the controversial Breonna Taylor attorney general" in news headlines of stories about him (Spocchia, 2020). Journalists are honoring her by saying her name instead of his. 


\section{Summary of Results: Hypotheses Revisited}

\section{Hypothesis 1 (H1)}

Hypothesis 1 stated Breonna Taylor's media afterlife exists in order to make police killings against Black Americans more palatable and important to white moderate audiences. This is supported through afterlives one through three: Breonna the Ideal Victim, Breonna the Victim of a Failed Raid and Breonna the Meme. Breonna the Ideal Victim as a narrative afterlife serves to wet the palate of moderate white audiences, it introduced them to a Black woman who defied their stereotypes. If a Black woman living a respectable life like Breonna could be killed in her own home, so too could they. The initial conversations around Breonna's murder did not center it as a race thing, but rather one that was random and unfortunate. She dedicated her life to helping others, but she did so under a system that failed to preserve her own. Following this, Breonna the Victim of a Failed Raid as an afterlife led those now emotionally invested in the dead innocent Black woman to consider placing blame for her death to the beloved police. The final supporting afterlife Breonna the Meme is the story of what happens when these watereddown retellings of what happened to her brings forth activism. The hypothesis is the cause of this effect. It reveals what happens when widespread publicity and celebrity activism coalesce to bring about a "woke" new anti-Blackness in performative activism/allyship or digital Blackface.

\section{Hypothesis 2 (H2)}

Hypothesis 2 stated that media framing would lead us to question Breonna's legitimacy as a central part of our social justice activism to undermine the Black Lives Matter protests and activism. While supported through the fifth afterlife Breonna the Catalyst of Retaliatory Violence, this hypothesis did not characterize very much of the data in the sample. This could be due to my choice of database NexisUni not returning very many articles that were explicitly 
conservative leaning, this could also be due to conservative publications not giving Breonna or her story very much attention. There were only two such articles that appeared in the data, as such they did not merit a code or a place in any of the seven narrative afterlives. However, I will include discussion of them here as honorable mentions and to qualify how these articles support the hypothesis.

These two articles said things like "it appears Mr. Walker used his girlfriend as a shield" as their explanation for why Breonna died (Sundance, 2020). There was no reflexivity or questioning of any of the LMPD's actions. They attacked the left media for pushing false facts about some big looming agenda that they failed to name. They alluded to there being some kind of grand conspiracy unfolding because Breonna Taylor was allowed to be remembered and mourned. These articles read resentful of this attention, of her narrative afterlife. The other article is brief its headline states: "Shocking Report Leaked in Breonna Taylor Death Investigation Shows How Involved She Really Was" (MJA, 2020). It claims they received exclusive new evidence that "shows just how involved Taylor was in Glover's drug enterprise and why the police were at her house the night of her death" yet it never extends how the evidence proves their claims (MJA, 2020). It merely draws readers looking for conformation bias in and attached the new information as an attachment knowing most would not open it and attempt to do any corroboration of their own.

\section{Summary}

There were very many narrative afterlives of Breonna Taylor, most seemed to allow us to process and explore our wanning distrust of the U.S. justice system. Breonna Taylor's revival in the media shows us that real work still needs to be done. It highlights that much of this work needs to originate within all of us, as well as in the institutions and practices we are now 
condemning. Perhaps her death has made us aware that silent and unquestioning of unjust legislations and state practices have existed for far too long. Perhaps through her death we are mourning the sense of justice that watching the footage of George Floyd's murder shattered. Maybe from this new vantage point of reflection, viewing (in)justice through her eyes, we can build a better world. 


\section{CHAPTER V: CONCLUSION: WHAT BRE LEFT BEHIND: THE LEGACY OF BREONNA}

\section{TAYLOR}

An innocent woman was killed in her home, by the police, and it took two months for us to hear about it. Journalists and political commentators have argued our delay in care and media attention was due to the then-emerging pandemic, first declared two weeks prior to her murder; compounded by the fact Breonna Taylor was a woman and a Black one at that (AP Newswire, 2021). Hill (2020: 89) states that while Breonna "met all of the bourgeois liberal standards of the 'worthy victim,"' it still took the death of George Floyd for us to become outraged by hers. Others argued that this invisibility was due to the lack of audiovisual evidence of what was done to Breonna. There was no video evidence of what happened to Trayvon Martin, yet we still rallied behind him. There were audiovisual remnants of Sandra Bland's encounter with police, yet the societal response to her death did not come close to reaching the same level of outrage (Hill, 2020). The disparities in care and media attention are not about evidence, but the identity of the victim, male or female. Our living present is becoming history, as it is constantly being documented and curated in the news and on social media (Shaw, 2019). As such, it is important we analyze it in real time before political meaning making has the chance to re-color events and our perceptions of them. This chapter first discusses how the first six narrative afterlives fit into and contribute to the literature base. Thereafter, the thesis concludes with my vision of the future, as told through the seventh and final afterlife of Breonna's legacy as a decolonizing lens.

\section{The Seven Narrative Afterlives in Context}

It is important to first note and remember that prior to becoming a martyr for the Black Lives Matter movement, Breonna Taylor was human, just like the rest of us. For the entirety of the twenty-six years she spent here on Earth, she was loved and noted for having been driven by 
her compassion for others ("Justice Denied," 2020). She was "more than the [event] that made us know [her]." And she "should not be reduced to [her death] at the hands of a corrupt police force" (Gagliardo-Silver, 2020; para. 5). Jeanne Theoharis's (2018) A More Beautiful and Terrible History: The Uses and Misuses of Civil Rights History, allows a vantage point from which to approach the erasure of the human being behind the movement. The narrative afterlives of Breonna Taylor uncovered some subtle ways slavery and genocide still linger in places we cannot immediately see or articulate (King, 2019). This section illustrates how Breonna's afterlives serve as a social and political autopsy of U.S. anti-Blackness.

The first major afterlife, Breonna the Ideal Black Victim, emerges from the historic context. We have always had a habit of presenting "Black victims as perfect in order to justify our cries for justice" (Hill, 2020; 84). In turn, the state looks to those deviations from perfection to retroactively justify the deaths of Black people. The criminalization of Black victims through drug association seems to be the state's favorite mode of deflection of blame. The state initially tried to justify their actions in the raid that led to Breonna's death, by first charging her boyfriend with the attempted murder of a police officer, and then by trying to get her ex-boyfriend to implicate her in his drug operation (Sloan, 2020). When Sandra Bland died in a Texas jail, the state tried to make the case that she committed suicide because she was depressed as evidenced by the weed in her system (HBO, 2018). When George Floyd died, the state coroner's office claimed there were drugs in his system that might have contributed to his death; even after we all saw him get killed (Taylor, 2021).

The explanatory power within the prolific nature of the Breonna the Victim of a Failed Raid and Breonna the Victim of a Flawed System afterlives raises concerns that this type of framing in the media allows refuge to the police in extending them the benefit of the doubt. 
Readers were led to believe that no-knock raids happen all the time, and are generally uneventful, but that the raid on Breonna's home was aberrant. It does not acknowledge that the year before her murder, five of the LMPD officers who played a role in the raid of her home were also involved in a similar drug raid also premised on a poor investigation. The LMPD were given a tip about marijuana being grown and sold out of a home and did nothing with that information for so long, by the time of the bust someone new had moved into the home (Sloan, 2020). The difference between the two raids was that the LMPD got lucky the first time; no one stood their ground, so no one died. It was not the raid that failed Breonna, but the Louisville Police Department and the Attorney General's Office.

Most of the articles within the sample qualified that the involved officers were white positioning us to believe a Black officer would have somehow prevented Breonna from being murdered. As if half of the officers responsible for what happened to George Floyd were not people of color. It is not a question of white police officers but rather policing as a whole, the system as a whole-Attorney General Cameron, a Black man, is responsible for not presenting murder charges against the officers, because the system is designed to fail us in order to protect itself (Cobbina, 2019). The Breonna the Victim of (In)Justice afterlife shows that the issue at hand is so much deeper than white officers failing to preserve the life of a Black woman. It is the entirety of the institutions that comprise the system of justice coalescing that murdered Breonna and allowed her killers to walk freely. In order for justice to be realized the work cannot begin and end with officers behind bars, it must include interrogation and modification of all the contributing systems and practices, not just the police.

Breonna the Meme as an afterlife expands on the literature of the invisibility of Black women victims, providing us with some implications of this in the digital era. Never before have 
we seen online activism that trivializes the event it is protesting. The point of this activism seems not to be the end goal of attaining justice, but rather the act of participating in it - commodifying Breonna's death for personal gain. The memeification of Breonna Taylor allowed us to expand our consciousness, journalists and writers began tracking the phenomena and traced it back to digital Blackface. Digital Blackface shows that even when the circumstances of our conversations about Black people and therefore Black life are oriented around tragedy, pain, and suffering, it is decontextualized to become a point of humor, entertainment even. The "arrest the cops" memes are only the newest iteration of digital anti-Black violence, wherein "the pain and suffering of a Black woman is given a backseat to the humor people extract from their circumstances" (Coco, 2020). McKittrick (2006: xv) would attribute phenomena like this as a function of Black women's being "seemingly in place by being out of place." Meaning that because there is no room for Black women in our normative institutional frameworks, supplementary modes of justice seeking, like meme activism, will exist and proliferate, often with unseen and unintended consequences.

The Breonna the Catalyst of Retaliatory Violence afterlife reveals a further flaw in the premise of qualified immunity: police officers cannot be held personally liable for their actions, but a similar reciprocal protection does not exist for civilians. Police officers should not get to sue suspects for injuries incurred while performing their job and certainly not because their pride is hurt. Essentially the public are being held hostage to the egos, emotions, and self-control of its peacekeepers. The FBI defines terrorism as: "the unlawful use of force and violence against persons or property to intimidate or coerce a government, the civilian population, or any segment thereof, in furtherance of political or social objectives" (FBI, 2010). Under that framework, 
police officers who kill Black persons and refuse to do their jobs, endangering us in the process of their protest, are engaging in terrorism.

As of October 20, 2021, 878 people have been killed by the police in the United States, $26 \%$ have been Black, despite Black people only comprising 13\% of the population (Mapping Police Violence, (n.d.)). Comparatively, a grassroots site called The Officer Down Memorial Page named 383 officers killed in the line of duty this year (Honoring Officers Killed in 2021, (n.d)). However, the cause of death of 249 of those police officers they claimed were killed in the line of duty thus far this year, was Covid-19, 15 more were said to have died of heart attacks, none of these things are unique to the inherent danger of policing. This leaves only 119 officer deaths that could be attributed to the perils of their work environment. The power of how information is presented is apparent here as $69 \%$ of the officers reported to have died in the line of duty actually died of natural causes, a gross hyperinflation of the numbers. There is a nearly 7.5 times greater chance of getting killed by the police than a police officer getting killed at work. This statistic does not take intent into account, it does not differentiate between officers killed at work due to accidents and those killed willfully by a member of the public. This runs completely contrary to the first half of the Retaliatory Violence frame, which focused on fearmongering that engaging in demonstrations against police brutality leads to surges in violence against police officers.

The Breonna the Victim of Performative Justice afterlife underscores the relative lack of worth of a Black woman to the state; the only material justice served for Breonna was the wrongful death settlement her family received. On first glance, the $\$ 12$ Million settlement seems to be the least the state could do, however, upon a closer reading it shows us how far we still are away from realizing racial equality. When compared to the immediate justice response to the 
2017 shooting death of white woman Justine Ruszczyk Damond by a Black Minneapolis police officer, it appears fear is only a legitimate part of policing when those in question are Black. Justine was shot and killed in an alley, there were no witnesses, yet the officer was quickly charged and sentenced to 12.5 years for murder and her family was given a $\$ 20$ million settlement (BBC, 2019). In Breonna's case, it took international pressure and attention just to get the state to placate us with charges against one officer for damaging Breonna's neighbor's property, and there were witnesses in her case. It can also be concluded that the life of a Black woman was worth $\$ 8$ Million less than that of a white one. Breonna's life was only worth $60 \%$ of that of a white woman. This is a very clear connection to, and corroboration that, the $3 / 5$ ths Compromise that federally marked the political worth of enslaved Black persons as only $60 \%$ of that of a white person (Cooper, 2017). Recently, Republican lawmakers have rewritten the legacy of the 3/5ths Compromise, to weaponize it against the teaching of Critical Race Theory in schools, falsely asserting it was a move towards ending slavery (Sherman, 2021). But the state's performance of justice in the case of Breonna Taylor serves as a painful reminder, and rebuttal, that there was no positive motivation behind the compromise, Black people went from being worth nothing to $3 / 5$ ths of a person, where we remain today.

As presented throughout the last chapter, the media leads us to believe the only way forward in the wake of brutal and unnecessary police killings of Black Americans lies in police reform. This is interesting to note given that much of their reporting, if read through a decolonial lens, shows us that preserving the system of policing will never be revolutionary enough to be emancipatory. The issues these news articles claim to be troubling keep being repeated under new names and administrations, coded as institutional reform. This is why we need to center decolonization in criminology study. We need to explicitly represent and discuss reality as it 
stands, so we can see the normative ways we have attempted to reparate for those systemic harms are not working. We need not change the terms of the conversation we need to change the content (Mignolo, 2011). Changing the content means centering the narratives and visions of justice of those most impacted and marginalized: Black women (Crenshaw, et al., 2015; Ritchie, 2018). This thesis set out to begin uncovering the unique needs of Black women, when it comes to securing justice after a police shooting through use of Breonna Taylor's life and death as a framework. My humble hope is that this study will bring forth a new analytic consciousness from which we can begin reimagining a justice that includes Black women.

\section{Aspiration}

Christina Sharpe (2016: 109) proposes the use of "aspiration" as a theoretical thought project to imagine ways "to keep breath in the Black body" given the "virulent antiblackness everywhere" that robs us of it. To live "in the wake of slavery, in spaces where we were never meant to survive, or have been punished for surviving and for daring to claim or make spaces of something like freedom" is to aspire (Sharpe, 2016; 130). Simply put, aspiration here is embodiment of the desire to attain or accomplish Black life in the diaspora, in the afterlife of chattel slavery, to "ascend" and "soar" past those legacies (Sharpe, 2016; Merriam-Webster, (n.d.)). It is taking back Black dignities and futures out from under the suffocation of white supremacist settler colonial logics and violence. As such, it functions as a Black feminist decolonial project; to many, my rhetoric and pedagogy will be framed and perceived as violence, an attack on America vis-à-vis whiteness (Sharpe, 2016; Ciccariello-Maher, 2017; Mignolo, 2009, 2011). In questioning and challenging the normative performance of criminological study, this thesis lends itself to the renovation of our conception of the United States' system of (in)justice by imposing a "rebirth of dialectical thought" (Ciccariello-Maher, 2017; 2). The 
remainder of this thesis discusses my imaginings of a system of policing that better protects Black women from becoming collateral damage to the carceral state, like Breonna Taylor (Crenshaw, et al., 2015; Valencia, 2018).

\section{Future Studies}

In the commission of completing this study, several gaps in the literature emerged, provoking thought of future studies based on this one. Most closely aligned to this thesis, and offered as direct expansions, are a need to get a fuller picture of the (mis)representation of Breonna. To do so, a future study could focus on a similar content analysis using only non-U.S. publications as they were identified as offering the most inaccurate facts. The need to simultaneously compare the media representations and afterlives of Breonna Taylor and George Floyd also arises, allowing a deeper understanding of what misogynoir ${ }^{8}$ in justice looks and sounds like. Also highlighted by this study, comes the need to discursively analyze the Breonna Taylor grand jury proceedings. Another study could look at how the state assigns value to lives, how are police violence and wrongful death settlement numbers reached, and how does race, gender, and age, among other factors, contribute to this valuation of life?

\section{Policy Recommendations}

The pandemic forever changed how we live and work, it forced us to consider "what other parts of life as usual [were] no longer acceptable and should be challenged;" it was the perfect backdrop to force us to finally begin confronting systemic racism and police brutality (Cheung, 2020). Based on the issues highlighted and presented by the data, I propose that the following policy changes could lead us to a world where the unacceptability of what happened to

\footnotetext{
${ }^{8}$ Misogynoir is a term coined by U.S. scholar Moya Bailey for a kind of anti-Blackness specific to Black women, a combination of the two words misogyny and noir (French for Black). It offers an intersectional analysis of misogynistic violence and logic.
} 
Breonna Taylor would be difficult to replicate. The two biggest legislations that need to come to end are the War on Drugs, the political campaign and legal mandate that brought the police to Breonna's door, and qualified immunity, which protected the officers responsible for killing her from legal recourse.

The court system was shown to be a theater, in which (in)justice is performed as empty placation where Black women victims are concerned, therefore it is imperative several facets be reconfigured. The first modification should be centered around the grand jury process, currently the only rule appears to be the veil of secrecy surrounding it. Cannon Lambert, Sandra Bland's family's lawyer, stated of the grand jury process:

I think it's a farce...the criminal investigation. I bet you money that the D.A. down there will say all of the evidence that we presented to the grand jury was assessed and they made a determination that nobody should be charged. But the practical reality of a grand jury investigation is that it's not adversarial. I can't be there. I can't submit any evidence. They get to choose what evidence they submit and what evidence they don't. they may not choose to submit any of the dashcam video if they investigate Encinia [Bland's arresting officer]. They get to say Sandy was pulled over because she failed to use her turn signal, she got aggressive, and she had to be arrested. And there's no way for us to know whether or not that's the only evidence they give. Why? Because it's a secret proceeding, it's a secret proceeding no one will ever be able to access (HBO, 2018).

What is amazing about Breonna's case is the fact several jurors on her case sued in order to speak out about what did not get presented at the grand jury and they won. A judge ruled that they could break the veil of silence and secrecy, in addition to this, she ruled that the recordings and proceedings be released. This appears to be the first-time grand jury proceedings were made public access, setting a new legal precedent, meaning other controversial proceedings could potentially be released. An entirely new body of legal scholarship could emerge predicated on grand jury reformation because we dared to say the name Breonna Taylor. From this study of past proceedings should emerge guidelines prosecutors must meet; they must be held 
accountable to the people. Included in this reform should be an amendment to an adversarial system, meaning the other party should be able to present evidence of their own, it should also be open to the public. In the case of future police officer prosecutions, perhaps a specialty court or prosecutor that only prosecutes police officers - not appointed by a District attorney's office out to protect their friends, but a real outside counsel dedicated to state accountability. These theoretical changes would ensure the miscarriages of justice that allowed the police to get away with murdering Breonna Taylor in a court of law cannot be replicated in perpetuity.

\section{Imagine}

Imagine if the media and politicians had used the same designations, condemnation, and scorn placed on assemblages of Black protesters, on white militias and activists. The ones who have inflicted far greater harm, fear, and terror for far lesser goals. Like their perceived constitutional right to die and to kill others for the sake of their own convenience and pleasure. Not because members of their communities have been historically and systematically killed by the police and disparities in care. Not because every day they live under the banner of a very real fear they may never see their loved ones alive again. And very little legal recourse exists to ensure whoever is responsible will be held accountable. They simply wanted Black people to stop making them uncomfortable whining and complaining about racial and social justice. They aimed to eternally silence our beliefs and assertions that our lives should matter too, not instead of, but in tandem to, their white ones.

In the face of a global emergency, many militaristically fought to maintain that killer haircut for which they have always been complimented, and those craft beers that are supposed to be to die for. It was inconceivable that for a single moment of solidarity, we acknowledge that Black people are dying in disparate rates from explicit forms of state violence, and invisible ones 
in lack of access to equitable healthcare and concern. Through our desperate pleas for our lives, we brought people to the point of violence. Needless vigilante killings framed as protestmockery. Their answer to our cries, that our lives have not and will not matter to them.

Innocent lives ended out of an anger we are told we must make room for and understand. Anger that eventually this racial progress will call on them to make concessions that they will call oppression. Our demands for justice and racial progress were asking for too much too fast. And because we have been told to make room in our hearts for this anger and violence, the police took alive the white supremacist who killed nine Black people innocently worshiping at the Emmanuel Baptist church, and because he said he was hungry, took him to a drive through. While this same institution broke into Breonna Taylor's home and shot her dead, because they thought there was a possibility, they would find drug money. These same peacekeepers also tried to aggressively arrest George Floyd for using a counterfeit $\$ 20$ bill, killing him with their bare hands in the process.

When it became clear that all legal options, loopholes and acts of coercion by the president of the United States, the self-inaugurated resurrector of democracy, had failed to subvert the will of the people, Trump supporters stormed the nation's capital. They had guns and the intent and the tools to injure, to kill, and to make hostages out of lawmakers for the heinous and unacceptable act of fulfilling their oath to the people of this nation that elected them, rather than pledge undying fealty to the president. And unlike the brutality protesters were met with this summer from the police, for the most part this was allowed, the police only killed a single person. The deaths and injuries were the fault of the white power activists Trump told during the first presidential debate to "stand back and stand by" rather than the police, and the national guard that were deployed en masse in full riot gear this summer to incite fear and violence 
among non-violent Black protesters. Eleven police officers were injured in this single event. Throughout this act of what is no less than terrorism, I implored aloud to myself where were the officers who anointed themselves preservationists of democracy, of law and order? Where were the military grade weapons and tactics, they deployed last summer? What was it that allowed them to just stand by without fear and allow themselves to be senselessly injured while guns were pointed at them?

While this same reverence for human life did not exist when they fired indiscriminately out of fear at little Black boys at their own homes with toy guns, young Black teenagers with candy in their pockets "mistaken" for a gun, and young Black men suspiciously exercising in public. Lives cut short for the criminal act of being unintentionally "fear inducing."

Imagine now if there were a reciprocal burden white people must face in order to prove they belong among the ranks of the living. If they too were forced to awaken every day and reaudition for their humanity by playing respectability politics. Would we still be debating empirical reality? That the police are an occupying force in our nation. Treating those labeled deviant as enemy combatants that deserve to be put down using any means necessary; and that it is unacceptable? Would we be able to accept and mobilize behind the notion that police abolition means simply, decentering the police as the first line of defense for all social ailments? Could we build a society that is mutually beneficial and safe, dare I say free, for all? This is the realization of my decolonial criminology, the presence of equality beginning on the level of rhetoric, giving us the necessary tools to reshape and renovate our lived reality. 


\section{REFERENCES}

Abbotsford News. (2021, February 3). PHOTOS: Newly unveiled art installation pays tribute to Breonna Taylor at SFU. Abbotsford News.

ABC Premium News. (2020, October 21). A grand juror has revealed why US police officers who shot Breonna Taylor weren't charged with murder. ABC Premium News (Australia).

ABC Premium News. (2020, September 24). Breonna Taylor shooting sees former police officer Brett Hankison charged with wanton endangerment of her neighbours. ABC Premium News (Australia).

Abisoye, O. (2021, January 22). Breonna Taylor Jurors File Petition To Impeach Kentucky Attorney General. Daily Independent (Nigeria).

ACLU. (n.d.). Against drug prohibition. Retrieved April 12, 2021, from https://www.aclu.org/other/against-drug-prohibition

Agozino, B. (2003). Counter-Colonial Criminology: A critique of Imperialist Reason, London: Pluto Press.

Agozino, B. (2004). Reparative Justice: A Pan-African Criminology Primer. In Pan African Issues in Crime and Justice, Kalunta-Crumpton and Agozino, B. (eds), 228-248.

Alexander, H. (2020, July 31). Florida sheriff threatens to pull security for Tampa Bay Rays after official team tweet called for the arrest of officers involved in Breonna Taylor's death. MailOnline.

Alexander, M. (2012). The New Jim Crow. New York, NY: New Press. Amatulli, (2020, August 20). LeBron James, Lakers Wear Crossed-Out MAGA Hats Demanding Justice For Breonna Taylor. The Huffington Post. 
Amatulli, J. (2020, August 7). Oprah Winfrey Demands Justice For Breonna Taylor With 26 Kentucky Billboards. The Huffington Post.

Andrews, T. (2020, July 3). The debate around breonna taylor memes: Do they bring attention to the cause or trivialize her death? The Washington Post. Retrieved September 17, 2021, from https:/www.washingtonpost.com/technology/2020/07/03/breonna-taylor-memes/.

Aniftos, R. (2020, June 5). Beyonce Demands 'Justice' for Breonna Taylor on Her 27th Birthday. Billboard.

Aniftos, R. \& Kaufman, G. (2020, July 16). YBN Cordae, Trae Tha Truth Arrested at Breonna Taylor Protest in Louisville. Billboard.

AP news wire. (2020, December 30). Officer who sought warrant at Taylor home could be dismissed. The Independent (United Kingdom).

AP news wire. (2020, December 31). Officer in Breonna Taylor case fights move to fire him. The Independent (United Kingdom).

Ap News wire. (2020, December 4). Council won't appoint new prosecutor in Breonna Taylor case. The Independent (United Kingdom).

AP news wire. (2020, December 8). Taylor's family praises Virginia ban on no-knock warrants. The Independent (United Kingdom).

AP news wire. (2020, November 11). Lawsuit: Former Louisville officer sexually assaulted woman. The Independent (United Kingdom).

AP news wire. (2020, November 16). 3rd Breonna Taylor grand juror: Cops 'got slap on the wrist.' The Independent (United Kingdom).

AP news wire. (2020, November 16). All protest charges dropped against Kentucky lawmaker. The Independent (United Kingdom). 
AP news wire. (2020, November 17). Man indicted in shooting of 2 officers at Taylor protest. The Independent (United Kingdom).

AP news wire. (2020, November 2). Breonna Taylor memorial moving to an African American museum. The Independent (United Kingdom).

AP news wire. (2020, October 14). Breonna Taylor's boyfriend recounts her shooting by police. The Independent (United Kingdom).

AP news wire. (2020, October 20). Judge says Breonna Taylor grand juror can speak about case. The Independent (United Kingdom).

AP news wire. (2020, October 21). Officer in raid says Breonna Taylor 'didn't deserve to die.' The Independent (United Kingdom).

AP news wire. (2020, October 23). 2nd Breonna Taylor grand juror criticizes proceedings. The Independent (United Kingdom).

AP news wire. (2020, October 28). Breonna Taylor grand jurors: Officers deserved more charges. The Independent (United Kingdom).

AP news wire. (2020, October 30). Official: Rifle shell casings found at Breonna Taylor scene. The Independent (United Kingdom).

AP news wire. (2021, January 21). Kentucky to study warrant process after Taylor shooting. The Independent (United Kingdom).

AP news wire. (2021, January 4). Kentucky officers in Breonna Taylor face termination hearing. The Independent (United Kingdom).

AP news wire. (2021, January 6). 2 detectives involved in Breonna Taylor raid are fired. The Independent (United Kingdom). 
AP news wire. (2021, January 8). Police chief's past sows doubts in wake of Taylor's death. The Independent (United Kingdom).

AP news wire. (2021, March 12). Federal look into Breonna Taylor's death casts a wider net. The Independent (United Kingdom).

AP news wire. (2021, March 13). In Louisville, Breonna Taylor's family honors her legacy. The Independent (United Kingdom).

AP news wire. (2021, March 8). Judge ends shooting case against Breonna Taylor's boyfriend. The Independent (United Kingdom).

Arriola, L. R. (2013). Protesting and Policing in a Multiethnic Authoritarian State: Evidence from Ethiopia. Comparative Politics, 45(2), 147-168. doi:10.5129/001041513804634271

Associated Press State \& Local. (2021, February 4). Fired officer in Breonna Taylor case wants trial venue moved.

Associated Press. (2020, September 23). Breonna Taylor: Timeline of events in case. Retrieved March 17, 2021, from https://www.fox5dc.com/news/breonna-taylor-timeline-of-eventsin-case

Associated Press. (2021, January 29). Civil rights attorney Ben Crump hired by family of bodyslammed teen; Crump has previously represented the families of Trayvon Martin, Ahmaud Arbery, Breonna Taylor, George Floyd and Jacob Blake. Tampa Bay Tim Astor, M. (2020, August 25). Daniel Cameron, Kentucky A.G., Speaks at the R.N.C.: Full Transcript. The New York Times.

Atkinson, B. (2020, December 1). Attorney for George Floyd, Breonna Taylor families is VSU's keynote graduation speaker. The Progress-Index (Petersburg, Virginia). 
Atkinson, B. (2020, December 7). Breonna Taylor's aunt tells Virginia bill-signing ceremony her niece 'still needs justice'. The Progress-Index (Petersburg, Virginia).

Atkinson, K. (2020, December 8). Miley Cyrus, Bernie Sanders \& Breonna Taylor's Mom Among 2020 Billboard Women in Music Presenters. Billboard.

Atlanta Journal Constitution. (2021, March 9). Judge throws out criminal charges against Breonna Taylor's boyfriend. Atlanta Journal Constitution Online.

Baptist, E. E. (2016). Half has never been told: Slavery and the making of american capitalism. New York, NY: Basic Books.

Barbaro, M., Mills, A., Chaturvedi, A., Guillemette, D., Young, A. L., Anderson, L., \& Spiegel, A. (2020, September 9). The killing of Breonna Taylor, part 1. The New York Times. Retrieved September 30, 2021, from https://www.nytimes.com/2020/09/09/podcasts/thedaily/breonna-taylor.html.

Barbaro, M., Mills, A., Chaturvedi, A., Guillemette, D., Young, A. L., Anderson, L., \& Spiegel, A. (2020, September 10). The killing of Breonna Taylor, part 2. The New York Times. Retrieved September 30, 2021, from https://www.nytimes.com/2020/09/10/podcasts/thedaily/Breonna-Taylor.html.

Basit, T. (2003). Manual or electronic? The role of coding in qualitative data analysis. Educational Research, 45(2), 143-154. https://doi.org/10.1080/0013188032000133548 BBC. (2019, May 4). Justine Damond: US City of Minneapolis pays family \$20m. BBC News. Retrieved October 19, 2021, from https://www.bbc.com/news/world-us-canada-48158787. BBC. (2020, July 16). George Floyd: What happened in the final moments of his life. Retrieved March 08, 2021, from https://www.bbc.com/news/world-us-canada-52861726 
Belam, M. (2020, September 23). Breonna Taylor decision: two officers shot in Louisville as protests erupt across US - as it happened. The Guardian (London).

Bell, C. (2020). Code of the School: Punishment, Violence, and Victimization in Public High Schools. Manuscript in preparation.

Bernucca, C. (2020, July 24). NBA Notebook: LeBron James calls for justice for Breonna Taylor. DPA International (Englischer Dienst).

Better Georgia. (2020, July 20). Breonna Taylor petition hits 10 million signatures. Better Georgia.

Better Georgia. (2020, September 2). Ben Crump Denounces Prosecutors' Efforts to Frame Breonna Taylor. Better Georgia.

Better Georgia. (2021, March 11). Breonna Taylor's boyfriend finally cleared in police-raid gone wrong. Better Georgia.

Better Georgia. (2021, March 13). Justice for Breonna Taylor Campaign seeks to outlaw noknock warrants. Better Georgia.

Bhatia, S., Athreya, V., Grenyer, R., \& Macdonald, D. W. (2013). Understanding the role of representations OF human-leopard conflict in MUMBAI Through Media-Content Analysis. Conservation Biology, 27(3), 588-594. https://doi.org/10.1111/cobi.12037

Bird, D. (2020, July 15). Real Housewives' Porsha Williams arrested during Black Lives Matter protest; Real Housewives of Atlanta star Porsha Williams has been filmed, being restrained by cops as the reality star was taking part in a Breonna Taylor protest. Daily Star Online.

Bittenbender, S. (2021, January 25). Three Breonna Taylor grand jurors file impeachment petition against Kentucky AG. College Heights Herald: Western Kentucky University. 
Blue Virginia. (2020, December 7). Video: Gov. Northam Ceremonially Signs 'Breonna's Law' Prohibiting Use of No-Knock Search Warrants in Virginia. Blue Virginia.

Blum, J. (2020, November 14). Missouri's First Black Congresswoman: GOP Colleagues Called Me 'Breonna Taylor.' The Huffington Post.

Blum, J. (2020, September 2). Naomi Osaka Wears 'Breonna Taylor' Mask During First Match Of U.S. Open. The Huffington Post.

Bogel-burroughs, N. (2020, May 14). Months after LOUISVILLE police KILL woman in her Home, Governor calls for review. Retrieved March 04, 2021, from https://www.nytimes.com/2020/05/14/us/breonna-taylor-louisville-shooting.html

Bogel-Burroughs, N. (2020, May 14). Months After Louisville Police Kill Woman in Her Home, Governor Calls for Review. The New York Times.

Bogel-Burroughs, N. (2021, March 08). What to know about the trial of Derek chauvin. Retrieved March 09, 2021, from https://www.nytimes.com/live/2021/derek-chauvin-trialexplained

Bond, K. (2020, June 5). Kanye West to pay George Floyd's daughter's college tuition fees as part of a \$2million donation; The rapper's donation has been provided to charities associated with Floyd, Ahmaud Arbery and Breonna Taylor. standard.co.uk

Booker, B. (2021, January 06). 2 Louisville police Officers connected To Breonna Taylor's death have been fired. Retrieved March 08, 2021, from https://www.npr.org/2021/01/06/953285549/two-louisville-police-officers-connected-tobreonna-taylor-shooting-have-been-fi

Bouldin, A. (2020, November 24). Investigative Documentary 'Say Her Name: Breonna Taylor,' releases new details in the Breonna Taylor case. Better Georgia. 
Brazzell, M. (2021, May 28). We keep us safe: The transformative justice movement. ROAR Magazine. https://roarmag.org/essays/transformative-justice-movement/.

Breed, A. G. (2018, August 10). 'The lost CAUSE': The women's group fighting for confederate monuments. Retrieved April 23, 2021, from https:/www.theguardian.com/usnews/2018/aug/10/united-daughters-of-the-confederacy-statues-lawsuit

Bremner, J. (2020, June 6). Protests 'Keeps Me Determined' Says Breonna Taylor's Mother. Newsweek.com.

Brice-Saddler, M., \& Mettler, K. (2019, December 04). George Zimmerman sues Trayvon MARTIN'S FAMILY, prosecutors for $\$ 100$ million. Retrieved February 18, 2021, from https://www.washingtonpost.com/nation/2019/12/04/george-zimmerman-sues-trayvonmartins-family-prosecutors-million/Butler, C. (2016). Abstraction Beyond a 'Law of Thought': On Space, Appropriation and Concrete Abstraction. Law and Critique, 27(3), 247-268. doi:10.1007/s10978-016-9186-Z

BROKAW, S. (2020, December 5). Breonna Taylor: Kentucky declines to appoint new special prosecutor. UPI.

Brookover, B. (2020, June 04). Twenty-eight years after Rodney King case, there's still no justice or peace: Bob Brookover. Retrieved December 14, 2020, from https://www.inquirer.com/phillies/george-floyd-protests-rodney-king-20200604.html

Brown, Y. (2015, August 17). The subtle linguistics of polite white supremacy. Retrieved April 08, 2021, from https://medium.com/@YawoBrown/the-subtle-linguistics-of-polite-whitesupremacy-3f83c907ffff

Bunch, W. (2020, July 27). Breonna Taylor and our morally bankrupt nation. The Philadelphia Daily News. 
Bunch, W. (2020, July 28). We can no longer remain silent; As long as Breonna Taylor's killers walk the streets, none of us are truly free. The Philadelphia Inquirer.

Buncombe, A. (2020, October 15). Exclusive: Breonna Taylor's mother on her daughter's legacy, Trump and race in America. The Independent (United Kingdom).

Burke, D. \& Mansfeild, K. (2020, June 28). One dead and another injured after gunman 'opens fire' at Breonna Taylor protest; A man has died in a shooting at Kentucky's Jefferson Square Park -which has become the focus of protests against the death of Breonna Taylor, who was killed in a police raid of her home. mirror.co.uk.

Burke, M. (2020, July 22). Breonna Taylor petition draws 10M signatures, 2nd-highest ever on website. NBCNEWS.com.

Burke, M. (2020, October 14). 'What war probably Sounds like': Breonna Taylor's boyfriend recalls her fatal shooting. Retrieved March 04, 2021, from https://www.nbcnews.com/news/us-news/what-war-probably-sounds-boyfriend-breonnataylor-recalls-her-fatal-n1243426

Burke, M. (2021, January 21). Ex-Louisville officer charged in Breonna Taylor case wants trial venue moved. NBCNEWS.com. 
Business Wire. (2020, August 17). BET Her, the Network Dedicated to Black Women, Partners With PlayersTV to Air Kyrie Irving's Breonna Taylor Special, "\#SayHerName, Justice For Breonna Taylor"; The One-hour Special Premieres Saturday, August 22 at 9 PM ET/PT Only on BET Her and Saturday, August 29 at 11 PM ET/PT on BET; ---; In addition to driving action around Breonna Taylor's case, the special will feature panel conversations with Kyrie Irving, Common, Jemele Hill, Dr. Brittney Cooper, Congresswoman Ayanna Pressley, Brittany Packnett Cunningham, Black Lives Matter co-founder Alicia Garza, among other leading voices on the frontlines of the movement; \#JusticeForBreonnaTaylor. Business Wire.

Butler, P. (2017, August 11). US justice is built to humiliate and oppress black Men. it starts with The chokehold... Retrieved March 04, 2021, from https://www.theguardian.com/usnews/2017/aug/11/chokehold-police-black-men-paul-butler-race-america

Butler, P. (2017, August 14). Sexual torture: American policing and the harassment of black men. Retrieved March 04, 2021, from https://www.theguardian.com/usnews/2017/aug/14/stop-and-frisk-policing-black-men-torture-sexual-harassment-paulbutler

Butler, P. (2017). Chokehold: Policing Black Men. The New Press.

Carey, I. (2019, October 08). Outrage over image of George Zimmerman SIGNING bag of Skittles. Retrieved February 18, 2021, from https://www.fox26houston.com/news/outrageover-image-of-george-zimmerman-signing-bag-of-skittlesCiccariello-Maher, G. (2017). Decolonizing dialectics. Durham, NC: Duke University Press. 
Carrega, C., \& Ghebremedhin, S. (2020, November 17). Timeline: Inside the investigation of Breonna Taylor's killing and its aftermath. Retrieved March 17, 2021, from https://abcnews.go.com/US/timeline-inside-investigation-breonna-taylors-killingaftermath/story?id $=71217247$

Cave, D., Albeck-ripka, L., \& Magra, I. (2020, June 06). Huge crowds around the Globe march in solidarity against police brutality. Retrieved March 11, 2021, from https://www.nytimes.com/2020/06/06/world/george-floyd-global-protests.html

CBS/AP. (2021, March 09). Georgia house votes to repeal Civil War-era citizen's Arrest law a year after AHMAUD Arbery killed. Retrieved April 22, 2021, from https://www.cbsnews.com/news/georgia-house-repeal-citizen-arrest-law-ahmaud-arberydeath/

CGTN. (2020, June 3). World leaders CONDEMN George Floyd killing as violence spreads in U.S. Retrieved March 11, 2021, from https://news.cgtn.com/news/2020-06-03/Worldleaders-condemn-George-Floyd-killing-as-violence-spreads-in-U-S-R1Q3fbg9Es/index.html

Chaney, C., \& Robertson, R. V. (2013). Racism and Police Brutality in America. Journal of African American Studies, 17(4), 480-505.

Chaturvedi, A. (2020, September 11). Investigating the Killing of Breonna Taylor; the daily newsletter. The New York Times.

Cheung, H. (2020, June 08). George Floyd DEATH: Why US protests are so powerful this time. Retrieved March 04, 2021, from https://www.bbc.com/news/world-us-canada-52969905

Chudzinski, K. (2020, August 11). Jessica Alba and Olivia Wilde join celebs paying tribute to Breonna Taylor and call for justice 150 days after her death. MailOnline. 
Clayton, A. (2021, July 22). They lost loved ones to gun violence. then their grief was politicized. The Guardian. https://www.theguardian.com/us-news/2021/jul/22/gunviolence-families-defund-police-movement?fbclid=IwAR1E7EOhVbpAPbyIRfx_5cleWSFW84eA79O0-eorLD-hkn0jd5Q0aUxNg.

Clements, S. (2013, February 14). The war on drugs has Screwed black people and now it's coming for white people. Retrieved April 23, 2021, from https://www.vice.com/en/article/nnmxa8/americas-war-on-drugs-is-the-holocaust-in-slowmotion

CNN Wire. (2020, December 28). A bust of Breonna Taylor was damaged in an apparent act of vandalism. CNN.

CNN Wire. (2020, December 5). Kentucky board denies request from Breonna Taylor's family for special prosecutor. CNN.com.

Cobbina, J. (2019). Hands up, don't shoot: Protesting the police in Ferguson and Baltimore. New York, NY: New York University Press.

Coco, J. (2020, July 4). Breonna Taylor is not a meme. Medium. Retrieved September 17, 2021, from https://medium.com/outerlands/breonna-taylor-is-not-a-meme-fa500ab2381b.

Congressional Documents and Publications. (2020, May 28). House Judiciary Committee Democrats Demand DOJ Open Investigations in Response to Recent Murders of Ahmaud Arbery, Breonna Taylor, and George Floyd; Pledge Additional Oversight and Legislation. Congressman Hank Johnson's office. (2015, April 03). Rep. Johnson reintroduces bipartisan bill to de-militarize police. Retrieved October 16, 2020, from https://hankjohnson.house.gov/media-center/press-releases/rep-johnson-reintroducesbipartisan-bill-de-militarize-police 
Cooper, T. (2017, November 2). The 3/5 compromise still affects us today... Medium. Retrieved October 26, 2021, from https://medium.com/@taikeincooper/the-3-5-compromise-stillaffects-us-today-59aadf144d0d.

Coppedge, M., Gerring, J., Altman, D., Bernhard, M., Fish, S., Hicken, A., . . Teorell, J. (2011). Conceptualizing and Measuring Democracy: A New Approach. Perspectives on Politics, 9(2), 247-267. doi:10.1017/S1537592711000880

Cornell Law School. (n.d.). presumption of innocence. Legal Information Institute. https://www.law.cornell.edu/wex/presumption_of_innocence.

Costello, D., McLaren, M., Robinson, C. T., Loosemore, B., \& Ladd, S. (2020, May 28). 'no justice, no peace': 7 people shot amid downtown Louisville protests for Breonna Taylor. Journal. Retrieved October 13, 2021, from https://www.courierjournal.com/story/news/2020/05/28/breonna-taylor-shooting-protesters-rally-downtownlouisville/5280279002/.

Covert, T. J., \& Wasburn, P. C. (2007). Measuring media BIAS: A content analysis of time and Newsweek coverage of domestic social Issues, 1975?2000. Social Science Quarterly, 88(3), 690-706. https://doi.org/10.1111/j.1540-6237.2007.00478.x

Crenshaw Kimberlé Williams, Ritchie, A. J., Anspach, R., Gilmer, R., \& Harris, L. (2015). (rep.). Say Her Name: Resisting Police Brutality Against Black Women. African American Policy Forum Center For Intersectionality And Social Policy Studies.

Daniels, C., \& Burnett, J. (2020, March 15). Family says victim OF officer-involved shooting was Accomplished EMT. Retrieved March 04, 2021, from https://www.whas11.com/article/news/local/family-says-victim-of-officer-involvedshooting-was-accomplished-emt/417-0f53a062-412f-448b-8990-6c13b2c98fa3 
Daragahi, B. (2020, June 10). Why the george floyd protests went global. Retrieved March 08, 2021, from https://www.atlanticcouncil.org/blogs/new-atlanticist/george-floyd-protestsworld-racism/

Davis, K., \& Heilbroner, D. (Directors). (2018, December 4). Say Her Name: The Life and Death of Sandra Bland [Video file].

De la Cretaz, B. (2020, May 13). Police shot Breonna Taylor in her own home in MARCH. Why are we just hearing her story now? Retrieved March 04, 2021, from https://www.refinery29.com/en-us/2020/05/9810753/breonna-taylor-louisville-policeshooting-death

de Menezes, J. (2020, August 19). LeBron James and LA Lakers teammates wear parody Make America Great Again cap to call for justice for Breonna Taylor; Several Lakers players arrived at their game against the Portland Trail Blazers wearing red caps that read 'Make America arrest the cops who killed Breonna Taylor' following her death at the hands of authorities in March. The Independent (United Kingdom).

Deliso, M. (2021, March 12). ABC news. Retrieved March 17, 2021, from https://abcnews.go.com/US/timeline-impact-george-floyds-deathminneapolis/story?id=70999322

Dillion, N. (2020, June 20). Ky. cop canned. Accused of 'blindly' shooting Breonna Taylor. Daily News (New York).

Dillon, N. (2020, August 14). 'Every day is still March 13' Mom speaks about Breonna Taylor's death. Daily News (New York). 
Doherty, J. B. (2016). Us Vs. Them: The Militarization Of American Law Enforcement And The Psychological Effect On Police Officers \& Civilians. Southern California Interdisciplinary Law Journal, 25, 416-450.

Dor, D. 2003. On newspaper headlines as relevance optimizers. Journal of Pragmatics 35:695721.

Drug Policy Alliance. (2020). A brief history of the drug war. Retrieved April 12, 2021, from https://drugpolicy.org/issues/brief-history-drug-war

Duvall, T. (2020, September 25). Breonna Taylor shooting: A Minute-by-minute timeline of the events that led to her death. Retrieved March 17, 2021, from https://www.courierjournal.com/story/news/local/breonna-taylor/2020/09/23/minute-by-minute-timelinebreonna-taylor-shooting/3467112001/

Duvernay, A. \& Moran, J. (2016) 13 ${ }^{\mathrm{TH}}$. USA.

Edwards, V. (2020, December 29). Two cops to be fired over Breonna Taylor killing: Louisville police to remove detective who obtained no-knock warrant - and second officer who shot the EMT three times. MailOnline.

Edwards, V. (2020, November 16). Third Breonna Taylor juror claims the investigation was incomplete and accuses prosecutors of only wanting to give cops who killed the EMT 'a slap on the wrist.' MailOnline.

Eligon, J. (2019, May 03). A Black Officer, a White Woman, a Rare Murder Conviction. Is It 'Hypocrisy,' or Justice? Retrieved December 13, 2020, from https://www.nytimes.com/2019/05/03/us/mohamed-noor-guilty.html 
EUR/Electronic Urban Report. (2020, December 2). Congresswoman-Elect Cori Bush Says She Was Mistaken for Breonna Taylor at Congressional Freshmen Orientation (Watch). EUR/Electronic Urban Report.

Fanon, F. (1967). A Dying Colonialism. Grove Press.

Fanon, F. (1969). Toward the African Revolution. Grove Press.

Farmer, J. (2021, February 3). Black Lives Matter is still crucial despite waning media attention. The Shorthorn: University of Texas - Arlington.

FBI. (2010, May 21). Terrorism 2002/2005. FBI. Retrieved October 19, 2021, from https://www.fbi.gov/stats-services/publications/terrorism-2002-2005.

Fieldstadt, E. (2021, March 3). Georgia district investigating teacher who said Breonna Taylor deserved to get shot. NBCNEWS.com.3-Mar-21 Elisha

Flynn, M. (2020, May 29). Seven shot in Louisville as protests turn violent nationwide overnight. Retrieved March 04, 2021, from https://www.washingtonpost.com/nation/2020/05/29/seven-shot-louisville-police-brutalityprotests-turn-violent-nationwide-overnight/

Fruen, L. (2020, May 12). Family of black EMT, 26, sues police after she was shot 'at least EIGHT times' in the middle of the night in her Kentucky apartment during 'botched' drugs raid for man who was already in custody. MailOnline.

Gagliardo-Silver, V. (2020, June 5). Today is Breonna Taylor's birthday. To truly honor her, we can't just pursue the cops who shot her; Reform or a handful of prosecutions isn't the answer to Breonna Taylor's death - it's nowhere near enough. The Independent.

Gamal, F. (2016). The Racial Politics of Protection: A Critical Race Examination of Police Militarization. California Law Review, 104, 979-1008. 
Garba, T., \& Sorentino, S. (2020). Slavery is a metaphor: A critical commentary on Eve Tuck and K. Wayne Yang's "decolonization is not a metaphor". Antipode, 0(0), 1-19.

Gaztambide-Fernández, R. (2014). Decolonial options and artistic/aestheSic entanglements: An interview with Walter Mignolo. Decolonization: Indigeniety, Education \& Society, 3(1), 196-212.

Gentner, D., \& Wolff, P. (2000). Metaphor and Knowledge Change. In E. Dietrich \& A. Markman (Eds.), Cognitive dynamics: Conceptual change in humans and machines (pp. 295-342). essay, Lawrence Erlbaum Associates.

Glover, S., Richards, C., Devine, C., \& Griffin, D. (2020, July 23). A key miscalculation by OFFICERS contributed to the tragic death Of Breonna Taylor. Retrieved March 04, 2021, from https://www.cnn.com/2020/07/23/us/breonna-taylor-police-shooting-invs/index.html

Goldberg, R. (2010). The Challenge Of Change: Social Movements As Non-State Actors. Utah Law Review.

Gottschalk, S. (2018, August 01). The infantilization of Western culture. Retrieved November 13, 2020, from https://theconversation.com/the-infantilization-of-western-culture-99556 Greenwald, D. (2021, February 4). Arizona OK's 'Justice for Breonna Taylor' Law Banning NoKnock Warrants, and More. The People's Vanguard of Davis.

Greenwald, D. (2021, January 25). Citizens, Including 3 Grand Jurors in Breonna Taylor Case, Want to Impeach Kentucky AG. The People's Vanguard of Davis.

Gross, J. (2020, May 21). F.B.I. to Investigate Shooting of Breonna Taylor by Louisville Police. The New York Times. 
Guardian Sport and Agencies. (2020, July 9). Philadelphia Union wear names of black Americans killed by police on shirts; Union honor Breonna Taylor, Eric Garner, others on shirt backs. Philadelphia win in their first match of MLS is Back tournament. The Guardian (London).

Habel, M. A., Liddon, N., \& Stryker, J. E. (2009). The HPV Vaccine: A Content Analysis of Online News Stories. Journal Of Women's Health, 18(3). https://doi.org/10.1089=jwh.2008.0920

Haines, E. (2020, May 12). Family seeks answers in fatal police shooting of Louisville woman in her apartment. Retrieved March 04, 2021, from https://www.washingtonpost.com/nation/2020/05/11/family-seeks-answers-fatal-policeshooting-louisville-woman-her-apartment/

Hair, C. (2020, September 26). Car rally calls for justice in Breonna Taylor case. The Columbian (Vancouver, Washington).

Hall, L. (2020, June 5). Kanye West creates college fund for George Floyd's daughter and makes \$2m additional donations; Rapper also offered to pay legal costs of families of Ahmaud Arbery and Breonna Taylor. The Independent (United Kingdom).

Hall, L. (2020, May 12). Breonna Taylor: Black healthcare worker 'shot at least eight times by police' in own home, lawsuit says; Police claimed they were executing a drug warrant when shooting took place. The Independent.

Hall, N. (2020, October 22). Anonymous Grand Juror Reveals Homicide Charges Never Presented in Breonna Taylor Case. The People's Vanguard of Davis (California).

Hall, R. (2020, September 23). Anger follows 'offensive' lack of charges for police officers who killed Breonna Taylor. The Independent (United Kingdom). 
Hansen, S. (2020, May 29). 7 People Shot In Louisville 1 In Critical Condition As Violent Protests Erupt Across The Country. Forbes.com.

Hassett-Walker, C. (2021, January 12). How you start is how you Finish? The Slave patrol and Jim CROW origins of policing. Retrieved April 19, 2021, from https://www.americanbar.org/groups/crsj/publications/human_rights_magazine_home/civil -rights-reimagining-policing/how-you-start-is-how-you-finish/

HBO. (2018). Say Her Name: The Life and Death of Sandra Bland. United States . Retrieved May 3, 2021.

Healy, J. (2020, September 08). Black, native American and fighting for recognition in Indian country. Retrieved April 28, 2021, from https://www.nytimes.com/2020/09/08/us/enslaved-people-native-americansoklahoma.html

Higham, A. (2020, June 4). Breonna Taylor: Who was Breonna Taylor? What happened to her?; BLACK LIVES MATTER protests have engulfed America after years of police brutality against black people. Who was Breonna Taylor and what happened to her? ExpressOnline.

Higham, A. (2020, September 13). Breonna Taylor: Why is Lewis Hamilton supporting her? What happened to her?; LEWIS HAMILTON has made headlines by wearing a T-shirt emblazoned with the words "Arrest the cops who killed Breonna Taylor". Who was Breonna Taylor? Express Online.

Hill, E., Tiefenthäler, A., Triebert, C., Jordan, D., Willis, H., \& Stein, R. (2020, June 01). How George Floyd Was Killed in Police Custody. Retrieved January 10, 2021, from https://www.nytimes.com/2020/05/31/us/george-floyd-investigation.html 
Hill, E., Tiefenthäler, A., Triebert, C., Jordan, D., Willis, H., \& Stein, R. (2020, May 31). How George Floyd was killed in police custody. Retrieved March 04, 2021, from https://www.nytimes.com/2020/05/31/us/george-floyd-investigation.html

Holiner, D. (n.d.). We need to talk about the memeification of Breonna Taylor's death. BUST. Retrieved September 17, 2021, from https://bust.com/feminism/197414-memeificationbreonna-taylor.html.

Holloway, K. (2018, October 07). 7 things the United daughters of the Confederacy might not want you to know about them. Retrieved April 23, 2021, from https://www.salon.com/2018/10/06/7-things-the-united-daughters-of-the-confederacymight-not-want-you-to-know-about-them_partner/

Holmes, I. (2021, February 3). No-knock search warrants began in Wisconsin, Rep. Myers wants to end them here She says it's the Badger State's responsibility to end the practice. Wisconsin Examiner.

Honoring Officers Killed in 2021. The Officer Down Memorial Page (ODMP). (n.d.). Retrieved October 27, 2021, from https://www.odmp.org/search/year/2021.

Housman, D. (2020, December 30). Louisville Police To Fire Two Officers Involved In Breonna Taylor Shooting; Taylor was killed in the Mar. 13 raid on her home. The Daily Caller.

Hubbard, S. (2021, March 13). Breonna Taylor died one year ago. The fight for justice is far from over. The Guardian (London).

i-Independent Print. (2020, December 30). Breonna Taylor statue smashed. i-Independent Print Ltd.

Iasimone, A. (2020, June 14). Beyonce Demands Justice for Breonna Taylor in Letter to Kentucky Attorney General. Billboard. 
Iasimone, A. (2021, March 13). Megan Thee Stallion \& Fashion Nova Donate $\$ 100 \mathrm{~K}$ to Breonna Taylor Foundation on Anniversary of Her Death. Billboard.

International Business Times. (2020, August 11). Celebrities Wear 'Arrest The Cops Who Killed Breonna Taylor' Shirts To Raise Awareness. International Business Times News.

International Business Times. (2020, August 19). LeBron James, Lakers Wear Fake MAGA Hats In Support Of Breonna Taylor. International Business Times News.

International Business Times. (2020, August 20). Upheaval On Social Media: Call For Justice For Breonna Taylor's Death Intensifies. International Business Times News.

International Business Times. (2020, July 15). 87 Face Felony Charges Over Breonna Taylor Protest At Kentucky Attorney General's Home. International Business Times News.

Itkowitz, C., \& Brice-Saddler, M. (2020, May 09). Father and SON charged in the killing of black Georgia JOGGER, Ahmaud Arbery, after Footage sparked outrage. Retrieved March 04, 2021, from https://www.washingtonpost.com/politics/2020/05/07/killing-ahmaudarbery-draws-condemnation-calls-prosecution/

Jack, F. (2020, December 31). Ben Crump Responds to Expected Firings of Det. Jaynes and Det. Cosgrove in Breonna Taylor Killing. EUR/Electronic Urban Report.

Jack, F. (2020, October 28). Breonna Taylor Grand Juror Calls Proceedings A 'Betrayal' in Exclusive Interview / WATCH. EUR/Electronic Urban Report.

Jack, F. (2021, January 24). 3 Breonna Taylor Grand Jurors File Petition to Impeach Kentucky AG Daniel Cameron. EUR/Electronic Urban Report.

Jacobs, M. S. (2017). The Violent State: Black Women's Invisible Struggle Against Police Violence. William \& Mary Journal of Race, Gender, and Social Justice, 24(1), 39-100. 
James, J. (2013). "Concerning Violence": Frantz Fanon's Rebel Intellectual in Search of a Black Cyborg. South Atlantic Quarterly, 112(1), 57-70. doi:10.1215/00382876-1891233

Jankowicz, M. (2020, July 6). The police warrant on Breonna Taylor's apartment was part of a gentrification drive, her family says. Business Insider US.

Jankowicz, M. (2020, July 6). The police warrant on Breonna Taylor's apartment was part of a gentrification drive, her family says. The Business Insider.

Jones, K., Hassan, C. \& Asmelash, L. (2020, May 12). A Kentucky EMT was shot and killed during a police raid of her home. The family is suing for wrongful death. CNN.com.

JustAnnet. (2021, April 10). Latasha Harlins: The 15-year-old murdered over Orange Juice. Medium. Retrieved October 21, 2021, from https://medium.com/crimebeat/latasha-harlinsthe-15-year-old-murdered-over-orange-juice-7cdee60c3834.

Kallingal, M. \& Romine, T. (2021, January 29). Louisville police department gets harsh rebuke in new report commissioned after Breonna Taylor's killing. CNN Wire.

Kappeler, V. E. (2014, February 7). A brief history of slavery and the origins of american policing. Retrieved April 19, 2021, from https://plsonline.eku.edu/insidelook/brief-historyslavery-and-origins-american-policing

Kaufman, G. (2020, July 6). Queen Latifah, Cardi B, Beyoncé, Lizzo and More Honor Breonna Taylor's Memory With Birthday Posts. Billboard.

Kaufman, G. (2020, June 16). Alicia Keys on Speaking Up For Breonna Taylor, 'Verzuz' Battle and New Song 'Perfect Way to Die.' Billboard.

Kaufman, G. (2020, June 4). Demi Lovato Encourages Fans to Send Cards to Kentucky Attorney General on Breonna Taylor's Birthday. Billboard. 
Kaufman, G. (2020, June 5). Selena Gomez Calls For Justice on Breonna Taylor's Birthday: She Would Have Been 'The Same Age I Am.’ Billboard.

Kaufman, G. (2020, June 5). Solange, Demi Lovato, Lizzo, Selena Gomez \& More Demand Justice For Breonna Taylor on Her Birthday. Billboard

Kaufman, G. (2020, September 3). Teyana Taylor Channels Breonna Taylor, George Floyd, Trayvon Martin in Powerful 'Still’ Video. Billboard.

Kelly, M., \& Eltohamy, F. (2021, February 25). Cherokee nation strikes down language that Limits citizenship RIGHTS 'By Blood'. Retrieved April 28, 2021, from https://www.npr.org/2021/02/25/971084455/cherokee-nation-strikes-down-language-thatlimits-citizenship-rights-by-blood

Kendi, I. X. (2021, April 19). Compliance will not save me. The Atlantic. https://www.theatlantic.com/ideas/archive/2021/04/compliance-will-not-save-mybody $/ 618637 /$.

Kenton, L. (2020, December 13). Tyler Perry Donates \$100K to Breonna Taylor's boyfriend for legal defense against lawsuit filed by one of the Louisville cops who shot dead the EMT, 26, during botched police raid. MailOnline.

Kenton, L. \& Mulraney, F. (2020, June 11). Louisville council votes to BAN no-knock warrants in honor of Breonna Taylor - just hours after cops released 'blank' report saying she suffered 'NO' injuries on night she was shot eight times and killed by cops. MailOnline.

Kim, S. (2021, January 7). More Than Twice As Many Arrested Protesting Breonna Taylor Verdict Than in Capitol Riots. Newsweek.com.

King Jr., M. L. (1963). Letter from a Birmingham Jail. Letter from a Birmingham Jail [King, Jr.]. N.p, n.d. Web. http://www.africa.upenn.edu/Articles_Gen/Letter_Birmingham.htm 
King, G. (2020, October 14). How Walker says he learned that Breonna Taylor did not survive and why her death leaves such a huge void in his life. CBS THIS MORNING. other, New York City, New York; CBS.

Kramer, R.C. (2016). State crime, the prophetic voice and public criminology activism. Critical Criminology, 24(1), 519-532.

Krippendorff, K. (1989). Content analysis. In E. Barnouw, G. Gerbner, W. Schramm, T. L.

Worth, \& L. Gross (Eds.), International encyclopedia of communication, 1, pp. 403-407.

Oxford University Press. http://repository.upenn.edu/asc_papers/226

Krippendorff, K. H. (2004). Content analysis: an introduction to its methodology. 2nd edition. Sage Publications, Thousand Oaks, California.

Ladson-Billings, G. (1998). Just What is Critical Race Theory and What's It Doing in a Nice Field Like Education? International Journal of Qualitative Studies in Education, 11(1), 724.

Ladson-Billings, G., \& Tate, W. F. (1995). Toward a Critical Race Theory of Education. Teachers College Record, 97(1).

Lamarre, C. (2020, June 25). Common, Rapsody \& More Rally in Kentucky to Demand Justice For Breonna Taylor. Billboard.

Lasswell, H. D. (1948). The structure and function of communication in society. In L. Bryson (Ed.), The communication of ideas (pp. 37-51). New York: Harper and Row.

Legal Monitor Worldwide. (2020, April 13). LMPD officers criticize judge for releasing man who initiated shootout that caused woman's death; suspect's lawyer has different story to narrate. Legal Monitor Worldwide. 
Legal Monitor Worldwide. (2021, January 23). Trial date set for former Louisville Metro officer charged for shooting in Breonna Taylor's house raid. Legal Monitor Worldwide

Legal Monitor Worldwide. (2021, January 27). Breonna Taylor grand jurors seek impeachment of Kentucky AG Cameron. Legal Monitor Worldwide.

Legal Monitor Worldwide. (2021, January 28). Breonna Taylor Grand Jurors Lodged Petition To Prosecute Attorney General Daniel Cameron. Legal Monitor Worldwide.

Leishman, R. (2020, August 4). Oprah Gives Her Usual O Magazine Cover Spot to Breonna Taylor. The Mary Sue.

Leonor, M. (2020, December 8). Northam marks passage of ban on no-knock warrants; Alongside members of Breonna Taylor's family, Northam ceremonially signs bill banning no-knock warrants. Richmond Times Dispatch (Virginia).

Lepore, J. (2020, July 13). The invention of the police. Retrieved April 19, 2021, from https://www.newyorker.com/magazine/2020/07/20/the-invention-of-the-police

Levenson, E. (2020, September 24). A timeline Of Breonna Taylor's case since police broke down her door and shot her. Retrieved March 17, 2021, from https://www.cnn.com/2020/09/23/us/breonna-taylor-timeline/index.html

Levenson, E., \& Carrega, C. (2020, September 15). Louisville agrees to PAY Breonna TAYLOR'S Family \$12 million and enact police reforms in historic settlement. Retrieved March 09, 2021, from https://www.cnn.com/2020/09/15/us/breonna-taylor-louisvillesettlement/index.html

Lieblich, E., \& Shinar, A. (2017). POLICE MILITARIZATION AND THE PRESUMPTION OF THREAT. Law and Ethics of Human Rights, 1-70. 
Lischer, R. (2018, April 4). Analysis | What Martin Luther King Jr. would think of Black Lives Matter today. The Washington Post. https://www.washingtonpost.com/news/acts-offaith/wp/2018/04/04/what-martin-luther-king-jr-would-think-of-black-lives-matter-today/.

London Free Press. (2020, August 8). Oprah billboards demand justice for Breonna Taylor; Kentucky. London Free Press.

Louisville-Jefferson County Metro Government. (n.d.). Details and timeline of the Breonna Taylor case. Retrieved March 17, 2021, from https://louisvilleky.gov/government/mayorgreg-fischer/details-and-timeline-breonna-taylor-case

Lovan, D. (2020, December 4). Council won't appoint new prosecutor in Breonna Taylor case. Associated Press State \& Local.

Lovan, D. (2020, June 11). Louisville bans 'no-knocks' after Breonna Taylor's death; Louisville bans 'no-knocks' after Breonna Taylor's death. Canadian Press.

Lovan, D. (2020, May 22). Prosecutor to drop charge against Breonna Taylor's boyfriend; Prosecutor to drop charge against Breonna Taylor's boyfriend. Canadian Press.

Lovan, D. (2021, March 12). Federal look into Breonna Taylor's death casts a wider net. Canadian Press.

Luperon, A. (2020, December 28). Sculpture of Breonna Taylor Was Vandalized, Police Now Are Investigating. Law and Crime.

Luperon, A. (2020, December 30). Interim Police Chief: Detective 'Lied' When He Said He Verified Underlying Basis of Breonna Taylor Search Warrant. Law and Crime.

Luperon, A. (2020, May 11). Attorney for Ahmaud Arbery's Father Now Represents Family of EMT Killed in Allegedly Botched Raid. Newstex Blogs Law and Crime. 
Lyman, B. (2021, January 23). REPORT: Attorney General Who Oversaw Breonna Taylor Case Facing Impeachment Petition. The Daily Caller.

Madani, D. (2020, December 30). Louisville police move to fire officers in Breonna Taylor case who got warrant, fired fatal shot. NBCNEWS.com.

MaGee, N. (2020, August 20). Jamarcus Glover, Suspect in Breonna Taylor Botched Raid, Arrested for Drug Trafficking. EUR/Electronic Urban Report.

MaGee, N. (2020, July 10). Outrage Over New York Times' Breonna Taylor Doc as Part of New Series. EUR/Electronic Urban Report.

MaGee, N. (2020, November 16). Cori Bush Says GOP Lawmakers Thought She was Breonna Taylor [VIDEO]. EUR/Electronic Urban Report.

MaGee, N. (2020, September 2). Breonna Taylor's Boyfriend Sues City, Louisville Police Over Botched Drug Raid [VIDEO]. EUR/Electronic Urban Report.

MaGee, N. (2021, January 7). Louisville Fires 2 White Officers Involved in Breonna Taylor Deadly Raid. EUR/Electronic Urban Report.

MailOnline. (2020, November 23). Breonna Taylor protest leader, 21, is shot dead 'during carjacking' near University of Louisville campus. MailOnline.

Mamo, H. (2020, August 20). Demi Lovato’s One Birthday Wish Is to Stand for Breonna Taylor. Billboard.

Mamo, H. (2020, June 10). Alicia Keys Leads All-Star Call for Justice for Breonna Taylor in Powerful PSA. Billboard.

Mamo, H. (2021, February 1). Rihanna Calls Out Kentucky Attorney General's Black History Month Post, Demands Justice For Breonna Taylor. Billboard. 
Mapping Police Violence. (n.d.). About the data. Retrieved March 10, 2021, from https://mappingpoliceviolence.org/aboutthedata/

Mapping Police Violence. Mapping Police Violence. (n.d.). Retrieved October 27, 2021, from https://mappingpoliceviolence.org/.

Martin, J. (2021, January 28). 75 Percent of Louisville Police Want to Quit Following Breonna Taylor Shooting: Report. Newsweek.com.

Martynova, I. A., \& Glukhov, G. V. (2015). Exploring the Echoes of Social Changes: Case Study of Language Infantilism. Mediterranean Journal of Social Sciences, 6(6), 3rd ser. doi:10.5901/mjss.2015.v6n6s3p315

Marx, K. (1843). Letters: Letters from the DEUTSCH-FRANZÖSISCHE Jahrbücher by Karl Marx. Retrieved March 25, 2021, from https://www.marxists.org/archive/marx/works/1843/letters/43_09.htm

Matt Mencarini, Costello, D. \& Duvall, T. (2020, November 30). Black homes targets of 'noknock' warrants; In Ky., Breonna Taylor died after such a search. USA TODAY.

Matthes, J., \& Kohring, M. (2008). The content analysis of media frames: Toward improving reliability and validity. Journal of Communication, 58(2), 258-279. https://doi.org/10.1111/j.1460-2466.2008.00384.x

Mattingly, D., \& Wise, J. P. (2020, March 13). Officers, suspect involved in deadly confrontation identified. Retrieved March 06, 2021, from https://www.wave3.com/2020/03/13/officers-suspect-involved-deadly-confrontationidentified/ 
Mattingly, D., \& Wise, J. P. (2020, May 16). Officers, suspect involved in deadly confrontation identified. Retrieved March 04, 2021, from https://www.wave3.com/2020/03/13/officerssuspect-involved-deadly-confrontation-identified/

Maynard, R. (2018). Reading Black Resistance through Afrofuturism: Notes on postApocalyptic Blackness and Black Rebel Cyborgs in Canada. TOPIA: Canadian Journal of Cultural Studies, 39, 29-47. doi:10.3138/topia.39.04

Mbembe, A. (2017). Critique of Black Reason. Durham, NC: Duke University Press.

McAlister, S. (2020, July 30). Piecing together the night Of Breonna Taylor's death. Retrieved March 17, 2021, from https://www.whas11.com/article/news/investigations/breonnataylor-case/breonna-taylor-timeline-death-investigation/417-1b3038f9-50a9-4dae-adfc6ede31f41657

Mcfadden, B. (2020, June 28). Shooting rampage in US as 'gunman opens fire' at protest crowd over death of black woman; A video on social media showed a man opening fire as people ran for safety at the park in Kentucky last night where demonstrators had gathered over the death of black woman Breonna Taylor. Daily Star Online.

McKittrick, K. (2006). Demonic Grounds: Black Women and the Cartographies of Struggle. Minneapolis: University of Minnesota Press.

McLaughlin, E. C. (2020, October 20). Breonna Taylor would be alive if police hadn't given her time to answer the door, officer involved in raid says. CNN.com.

Merriam-Webster. (n.d.). Afterlife. Merriam-Webster. https://www.merriamwebster.com/dictionary/afterlife. 
Metta, J. (2020, July 20). The problem of performative activism. Black Lives Matter|Al Jazeera. Retrieved October 19, 2021, from https://www.aljazeera.com/opinions/2020/7/20/theproblem-of-performative-activism.

Mizell, G. (2020, August 20). Why Does the W.N.B.A. \#SayHerName? Ask Angel McCoughtry. The New York Times.

MJA. (2020, August 29). Shocking Report Leaked in Breonna Taylor Death Investigation Shows How Involved She Really Was. iOTWreport.

MJA. (2020, December 29). Breonna Taylor sculpture smashed by vandals in California. iOTWreport.

Mulraney, F. (2020, July 7). Cops carried out Breonna Taylor's deadly no-knock warrant to search for suspects with no connection to her and previously called it off, her family claims. MailOnline.

Murray, R. (2016, July 22). The Consequences of Militarized Police Forces: Justin Murray. Retrieved October 16, 2020, from https://mises.org/blog/consequences-militarized-policeforces

Myrdal, G. (1944). An American dilemma: the Negro problem and modern democracy. New York: Harper. National Police Misconduct Reporting Project (2011). Retrieved from: http://www.policemisconduct.net/2010-npmsrp-police-misconduct-statistical-report/

Mystal, E. (2020, May 15). Breonna Taylor Was Murdered for Sleeping While Black. The Nation Blogs.

Mystal, E. (2020, September 2). The Authorities Are Still Gunning for Breonna Taylor. The Nation Blogs. 
Neimanis, A. (2019). The weather UNDERWATER: Blackness, White feminism, and the BREATHLESS SEA. Australian Feminist Studies, 34(102), 490-508. doi:10.1080/08164649.2019.1697178

Neimanis, A. (n.d.). The sea and the breathing. Retrieved April 17, 2021, from https://www.eflux.com/architecture/oceans/331869/the-sea-and-the-breathing/

Newsweek. (2020, June 5). 'Happy Birthday Breonna Taylor'—Woman Killed By Police Would Have Turned 27. Newsweek.com

Nolan, E. (2020, August 27). Oprah Erects 26 Breonna Taylor Billboards in Louisville Demanding Justice. Newsweek.com.

O'Connell, O. (2020, December 28). Breonna Taylor sculpture smashed by vandals in California. The Independent (United Kingdom).

O'Dowd, M. F., \& Heckenberg, R. (2020, June 24). Explainer: What IS decolonisation? Retrieved February 19, 2021, from https://theconversation.com/explainer-what-isdecolonisation-131455

Olito, F. (2020, June 03). Protests against police have broken out across the country. Here's how policing has evolved in the US since its beginnings in the 1600s. Retrieved April 19, 2021, from https://www.insider.com/history-of-police-in-the-us-photos-2020-6

Oriola, T. B. (2005). Biko Agonzino and the Rise of Post-Colonial Criminology. African Journal of Criminology \& Justice Studies, 2(1), 104-124.

Panetta, G. (2020, July 19). A Change.org petition demanding justice for Breonna Taylor is now the second most-signed in the site's history. The Business Insider.

Pariseau, L. (2020, August 13). Tobe Nwigwe Never Planned to Go Viral. Then He Rapped About Breonna Taylor. The New York Times. 
Patterson, W. L. (2017). WE CHARGE GENOCIDE: The crime of the government against the negro people. Place of publication not identified: INTL.

Paybarah, A. (2020, July 30). Louisville May Become Latest City to Declare Racism a Public Health Crisis. The New York Times.

Perano, U. (2020, August 8). Oprah Winfrey demands justice for Breonna Taylor in series of Louisville billboard buys. Axios.

Philips, D. (2021, February 28). Before George Floyd and Breonna Taylor, there was Latasha Harlins. NBC Los Angeles. Retrieved October 21, 2021, from https://www.nbclosangeles.com/news/national-international/latasha-harlins-mural-losangeles-riots/2537429/.

Phillips, H. (2020, June 4). Performative Allyship is deadly (here's what to do instead). Medium. Retrieved October 19, 2021, from https://forge.medium.com/performative-allyship-isdeadly-c900645d9f1f.

Picoult, J. (2016, October 25). Jodi PICOULT: How I confronted my racism. Retrieved March 25, 2021, from http://ime.com/4544356/jodi-picoult-confronts-racism/

Pilkington, E. (2021, April 23). Bones of black children killed in police bombing used in ivy league anthropology course. The Guardian. https://www.theguardian.com/usnews/2021/apr/22/move-bombing-black-children-bones-philadelphia-princetonpennsylvania?fbclid=IwAR3PFBK4d4BN4_L3WXsRjrOh3Yro9GJmMebIE4IKeRwcfU0 RehvZPWJbAo0.

Police Violence Map 2021. Mapping Police Violence. (2021, June 30). https://mappingpoliceviolence.org/. 
Povoledo, E., \& Hauser, C. (2020, June 03). Pope Francis calls unrest in u.s. 'Disturbing'. Retrieved March 11, 2021, from https://www.nytimes.com/2020/06/03/us/protests-popefrancis-obama-justin-trudeau-george-bush.html

Powers, P. (2001). Performing a discourse analysis. In The methodology of discourse analysis. Boston: Jones and Bartlett.

PR Newswire. (2020, July 7). PLAYERSTV will premiere \#SAYHERNAME: BREONNA TAYLOR on Wednesday, July 8th at 7 pm ET; The special features Producer and 6x NBA All-Star KYRIE IRVING, Award-winning artist COMMON and journalist JEMELE HILL among other leaders \& activists.

Purdue Writing Lab. (n.d.). Active versus passive voice // Purdue Writing lab. Purdue Writing Lab.https://owl.purdue.edu/owl/general_writing/academic_writing/active_and_passive_voi ce/active_versus_passive_voice.html.

Rahim, Z., \& Picheta, R. (2020, June 01). Thousands around the world PROTEST George floyd's death in global display of solidarity. Retrieved March 11, 2021, from https://www.cnn.com/2020/06/01/world/george-floyd-global-protests-intl/index.html

Randall, L. (2020, July 18). Breonna Taylor 'gasped for air for five minutes' after being shot by police; Breonna Taylor coughed and gasped for air for five minutes after police sprayed her home with bullets -a policeman also hit by the gunfire was treated first on the scene. mirror.co.uk.

Raskin, A. (2020, July 24). LeBron James honors Breonna Taylor in his first NBA bubble game by writing her name and the day she died on his sneakers then demands the cops who shot her dead be arrested. MailOnline. 
Retta, M. (2021, March 15). The internet's memory of Breonna Taylor. The Cut. Retrieved September 17, 2021, from https:/www.thecut.com/2021/03/internets-memory-breonnataylor.html.

Rezvani, A., Pupovac, J., Eads, D., \& Fisher, T. (2014, September 02). MRAPs And Bayonets: What We Know About The Pentagon's 1033 Program. Retrieved October 16, 2020, from http://www.npr.org/2014/09/02/342494225/mraps-and-bayonets-what-we-know-about-thepentagons-1033-program

Riotta, C. (2020, August 13). Breonna Taylor's family pushes for charges against officers after 'positive' meetings with mayor and attorney general; 'We need to take our city back so there won't be any more names. We don't need another Breonna Taylor, David McAtee or Tyler Gerth'. The Independent (United Kingdom).

Riotta, C. (2020, September 15). Breonna Taylor's family reaches 'substantial' settlement including major police reforms; Attorney representing Breonna Taylor's family confirms settle has been reached in wrongful death lawsuit. The Independent (United Kingdom).

Ritchie, A. (2017, August 16). How black women's bodies are violated as soon as they enter school. Retrieved March 04, 2021, from https://www.theguardian.com/usnews/2017/aug/16/black-women-violated-us-policing-racial-profiling

Ritchie, A. J. (2017). Invisible No More: Police Violence Against Black Women and Women Of Color. Boston, MA: Beacon Press.

Ritschel, C. (2020, September 8). Naomi Osaka says she stopped wearing hoodies over racism fears as she wears Trayvon Martin mask during US Open; Tennis star has also worn masks printed with names of Breonna Taylor, Ahmaud Arbery and Elijah McClain. The Independent (United Kingdom). 
Romano, A. (2020, August 10). "arrest the cops who killed Breonna Taylor": The power and the peril of a catchphrase. Vox. Retrieved September 17, 2021, from https://www.vox.com/21327268/breonna-taylor-say-her-name-meme-hashtag.

Roos, M. (2020, June 16). Attorneys for Breonna Taylor's Family Accuse Louisville Mayor of Cover-up. Newsweek.com.

Rowley, G. (2020, August 11). Cardi B Wishes More Male Rappers Would Speak Out About the Murder of Breonna Taylor. Billboard.

Ruiz, K. (2020, August 12). I haven't grieved because I don't want to face it': Breonna Taylor's sister recalls moment she learned her sister was shot dead by police in their Louisville home as she demands cops be arrested and charged. MailOnline.

Ruiz, K. (2020, October 22). Breonna Taylor raid cop blames her boyfriend for her death saying he put her in an 'impossible situation' when he fired first and if he really thought police were intruders he should've told her to 'hide'. MailOnline.

Ruiz, K. (2020, October 27). Breonna Taylor grand jurors say Louisville cops' actions were 'criminal' and 'negligent' the night of the fatal raid - as they speak out against the jury's controversial ruling in an anonymous interview. MailOnline.

Ruiz, K. (2021, January 22). Three Breonna Taylor grand jurors file petition to impeach Kentucky AG Daniel Cameron claiming he 'misrepresented their findings' in the case and lied about allowing them to consider homicide charges against the Louisville cops. MailOnline.

Ruiz, K. (2021, January 6). BREAKING NEWS: Louisville Police Department fires cop who shot Breonna Taylor dead and officer who obtained no-knock warrant that led to botched raid. MailOnline. 
Russo, C.H. (2020, September 2). Breonna Taylor's Boyfriend Sues Police Over Charges Filed After Botched Raid. The Huffington Post.

Salon. (2020, July 19). Abolishing the whole prison-industrial complex. Salon.com.

Salon. (2020, July 23). Was Breonna Taylor killing driven by gentrification? Studies suggest it's possible. Salon.com.

Saraisky, N. G. (2015). Analyzing Public Discourse: Using Media Content Analysis to Understand the Policy Process. Current Issues in Comparative Education, 18(1), 26-41.

Saunders, P. (2008). Defending the dead, confronting the archive: A conversation with $\mathrm{m}$. nourbese philip. Small Axe: A Caribbean Journal of Criticism, 12(2), 63-79. doi:10.1215/$12-2-63$

Schrader, A. (2021, March 13). Protesters march in cities across the country to demand justice for Breonna Taylor, one year after she was shot and killed by cops during a botched raid. MailOnline.

Sharpe, C. (2016, November 16). Lose your kin. Retrieved April 27, 2021, from https://thenewinquiry.com/lose-your-kin/

Sharpe, C. (2017, April 18). The weather. Retrieved April 17, 2021, from https://thenewinquiry.com/the-weather/

Sharpe, C. E. (2016). In the wake: On blackness and being. Durham; London: Duke University Press.

Shen, M. (2020, December 29). Ceramic bust of Breonna Taylor in Oakland is smashed by vandals in 'act of racism' - as artist raises more than $\$ 14,400$ to replace it with a bronze version. MailOnline. 
Sherman, M. (2021, May 6). Explainer: No evidence '3/5 compromise' aimed to end slavery. AP NEWS. Retrieved October 26, 2021, from https://apnews.com/article/electoral-collegeslavery-election-2020-race-and-ethnicity-government-and-politics0ef97970a86255bf89c897838fcdb335.

Simmons, K. C. (2014). The Coming Crisis in Law Enforcement and How Federal Intervention Could Promote Police Accountability in A Post - Ferguson United States. Wake Forest Law Review, 2, 101-112.

Slisco, A. (2020, July 20). NBA Player Demands Kentucky AG Charge Police in Breonna Taylor Case. Newsweek.com.

Sloan, D. (Producer). (2020, November 20). Say Her Name: Breonna Taylor [Television series episode]. In 20/20. New York City, NY: ABC.

Smith, S. (2020, July 10). Football team wear the names of black people killed by police on their shirts; Philadelphia Union took the opportunity to mark the lives of George Floyd, Breonna Taylor and other black people killed by police brutality, along with supporting the Black Lives Matter movement. mirror.co.uk.

Snyder, A. \& Riess, R. (2021, January 22). Three Breonna Taylor grand jurors among petitioners seeking to impeach Kentucky attorney general. CNN Wire.

Sommerlad, J. (2021, January 17). Breonna Taylor, George Floyd and a national reckoning. The Independent (United Kingdom).

Spocchia, G. (2020, November 10). Controversial Breonna Taylor attorney general joins Trump's election 'fraud' case. The Independent (United Kingdom).

States News Service. (2020, May 22). Harris, McBath Demand Independent DOJ Investigation Into Breonna Taylor Case. States News Service. 
Steiner, C. (2021, March 13). Breonna Taylor's Family Still Fighting for Justice One Year After Her Murder. The Mary Sue.

Stern, C. (2020, August 7). Oprah Winfrey puts her Breonna Taylor O Magazine cover on 26 BILLBOARDS across Louisville - and demands that the police officers involved with her killing be arrested and charged. MailOnline.

Stevens, T. (2021, January 27). New bill seeks to rein in Utah no-knock warrants like the one used in Breonna Taylor case. The Salt Lake Tribune.

Sullivan, H. (2020, September 24). Breonna Taylor protests: what we know so far. The Guardian (London).

Sundance. (2020, September 23). Everything the Media Claimed About Breonna Taylor's Death Was a Lie - Truth Surfaces - No Police Charged in Her Death. The Conservative Treehouse.

Taguchi, E., Kim, D., Rios, K., Rivas, A., \& Ghebremedhin, S. (2020, June 10). Breonna Taylor's mom seeking answers in her death: 'I haven't had time to ... grieve. Retrieved March 29, 2021, from https://abcnews.go.com/US/breonna-taylors-mom-seeking-answersdeath-time-grieve/story?id=71184205

Tampa Bay Times. (2021, January 6). 2 detectives involved in Breonna Taylor raid are fired; Louisville announced it hired a new police chief and fired two police officers involved in the death of the 26-year-old Black woman. Tampa Bay Times.

Tanno, S. (2020, October 30). Cop SUES Breonna Taylor's boyfriend for assault, battery and emotional distress he suffered when he shot him in the leg during botched raid. MailOnline. 
Targeted News Service. (2020, December 7). Hollywood Reporter: Color of Change's Rashad Robinson Says Breonna Taylor Decision Is a 'Wake-Up Call' to Hollywood. Targeted News Service.

Targeted News Service. (2020, May 23). Sen. Harris, Rep. McBath Demand Independent DOJ Investigation Into Breonna Taylor Case.

Targeted News Service. (2020, November 25). LDF Releases Report on Grand Jury Proceedings Involving Police Killing of Breonna Taylor, Calls for Special Prosecutor, New Grand Jury. Targeted News Service.

Targeted News Service. (2021, March 13). Black Women Call for Justice for Breonna Taylor, Demand End to Ongoing Police Violence. Targeted News Service.

Tatum, B. (n.d.). It's not so black and white: Discussing race and racism in the classroom. Retrieved March 25, 2021, from https://www.scholastic.com/teachers/articles/teachingcontent/its-not-so-black-and-white/

Taylor, D. B. (2020, May 30). George Floyd Protests: A timeline. Retrieved March 04, 2021, from https://www.nytimes.com/article/george-floyd-protests-timeline.html

The Associated Press. (2020, June 27). 1 fatally shot at Breonna Taylor protest park in Kentucky; 1 fatally shot at Breonna Taylor protest park in Kentucky. Canadian Press.

The Economist. (2020, June 11). The killing of George Floyd has sparked Global soul-searching. Retrieved March 23, 2021, from https://www.economist.com/international/2020/06/11/thekilling-of-george-floyd-has-sparked-global-soul-searching

The Globe and Mail. (2021, January 23). PETITION SEEKS REMOVAL OF KENTUCKY A-G OVER HANDLING OF BREONNA TAYLOR PROBE. The Globe and Mail (Canada). 
The National. (2020, September 1). US Open Day 1: Naomi Osaka wears 'Breonna Taylor' face mask, Coco Gauff defeated in first round. The National.

The New York Times. (2020, September 08). What to know about the death of George Floyd in Minneapolis. Retrieved March 04, 2021, from https://www.nytimes.com/article/georgefloyd.html

The New York Times. (2021, April 12). What to Know About the Death of Daunte Wright. The New York Times. https://www.nytimes.com/article/daunte-wright-death-minnesota.html. Thompson, J. (2021, March 12). Balloon release in memory of Breonna Taylor occurs before one-year anniversary of her death. College Heights Herald: Western Kentucky University.

Tighe, C. (2020, November 30). The black native american descendants fighting for the right to belong. Retrieved April 28, 2021, from https://www.nbcnews.com/news/nbcblk/blacknative-american-descendants-fighting-right-belong-n1248328

Togoh, I. (2020, June 15). Beyoncé Urges Justice For Breonna Taylor In Letter To Kentucky AG: Take Swift, Decisive Action In Charging The Officers. Forbes.com.

Toua, M. (2020, September 16). Breonna Taylor killed: When was Breonna Taylor killed why?; THE death of Black American woman Breonna Taylor has rocked the US as Black Lives Matter protests broke out all over the world following her death. When was Breonna Taylor killed, and why? Express Online.

Tuck, E., \& Yang, W. K. (2012). Decolonization Is Not a Metaphor. Decolonization: Indigeneity, Education \& Society, 1(1), 1-40.

US Fed News. (2021, February 5). HUDSON COUNTY COMMUNITY COLLEGE SPEAKER SERIES EVENT TO FEATURE BREONNA TAYLOR'S MOM. 
Vibe. (2020, May 23). Breonna Taylor: Family Files Lawsuit After Kentucky Police Kill 26Year-Old Black EMT. Vibe.

Villarreal, D. (2021, February 5). Louisville Cop Kim Burbrink Demoted for Involvement in Breonna Taylor Investigation. Newsweek.com.

Vogt, D. (2020, March 15). Coroner identifies woman shot and killed in officer-involved shooting. Retrieved March 06, 2021, from https://www.wave3.com/2020/03/15/coroneridentifies-woman-shot-killed-officer-involved-shooting/

Waddell, L. (2020, June 14). Beyoncé demands justice for Breonna Taylor in public letter after police shooting; Beyoncé turned the spotlight on Breonna Taylor as she called for justice over the police shooting. mirror.co.uk.

Wade, P. (2020, June 28). Pence Twists MLK's Legacy to Justify Refusing to Say Black Lives Matter. Rolling Stone. https:/www.rollingstone.com/politics/politics-news/pence-twistsmlk-legacy-black-lives-matter-1021596/.

Wang, J. (2018). Carceral Capitalism. South Pasadena, CA: Semiotext(e).

Washington Post Staff. (2020, October 26). George Floyd's America. The Washington Post. https://www.washingtonpost.com/nation/2020/10/12/george-floydamerica/?itid=lb_americas-racial-reckoning-what-you-need-to-know_3.

Waxman, O. B. (2017, March 06). The history of police in America and the first force. Retrieved April 19, 2021, from https://time.com/4779112/police-history-origins/

Weitzer, R. (2015). American Policing Under Fire: Misconduct and Reform. Society, 52(5), $475-$ 480. 
Wertz, F. J., Charmaz, K., McMullen, L. M., Josselson, R., Anderson, R., \& McSpadden, E. (2011). Five ways of doing qualitative analysis phenomenological psychology, grounded theory, discourse analysis, narrative research, and intuitive inquiry. New York, NY: Guilford Press.

Whitman, J. (2017, March 21). Nazis: America taught them racism in laws. Retrieved April 26, 2021, from https://time.com/4703586/nazis-america-race-law/

Williams, B., Hayden, C., \& Jorgensen, J. (2020, March 13). Man charged with attempted murder AFTER Detective injured trying to execute search warrant, one woman killed. Retrieved March 04, 2021, from https:/www.whas11.com/article/news/crime/officerinvolved-shooting-springfield-drive/417-108daa08-f4b0-4b52-ae8b-decd2c8b47f9

Williams, B., Hayden, C., \& Jorgensen, J. (2020, March 13). Man charged with attempted murder AFTER Detective injured trying to execute search warrant, one woman killed. Retrieved March 04, 2021, from https:/www.whas11.com/article/news/crime/officerinvolved-shooting-springfield-drive/417-108daa08-f4b0-4b52-ae8b-decd2c8b47f9

Winkler, A. (2011, May 25). MLK and His Guns. HuffPost. https://www.huffpost.com/entry/mlk-and-his-guns_b_810132.

Wood, J. (2020, June 5). 'I cannot stand it': family of Louisville man shot dead by police speak out; David McAtee, who used to feed cops for free, was killed during curfew in Louisville - and his death bore a striking resemblance to Breonna Taylor's George Floyd killing latest US updates. See all our George Floyd coverage. The Guardian (London).

Wright, M. (2020, November 13). Newly-elected congresswoman Cori Bush blasts Republicans who repeatedly called her BREONNA because she was wearing a face mask bearing Breonna Taylor's name. MailOnline. 
Wright, W. (2021, January 6). Police Chief Who Resigned After Fatal Shooting Will Lead Louisville Department. The New York Times.

Young, V. (2020, August 12). Breonna Taylor: A Young Life Full of Potential Taken Too Soon. Knight News: Queens College (University Wire).

Zakaria, R. (2016, June 16). Is Gone With the Wind's nostalgia for slavery acceptable? Retrieved April 22, 2021, from https://amp.theguardian.com/books/booksblog/2016/jun/16/is-gonewith-the-winds-nostalgia-for-slavery-acceptable-80-years-margaret-mitchell 
APPENDIX A: CODES AND FREQUENCIES

\section{CODES AND FREQUENCIES}

\begin{tabular}{|c|c|c|}
\hline CODE NAME & Description & Frequency/Count \\
\hline ARREST THE COPS & $\begin{array}{l}\text { References to "Arrest the cops" meme } \\
\text { activism }\end{array}$ & 29 \\
\hline ASSIGNED VALUE & $\begin{array}{l}\text { References to Breonna's stature in her } \\
\text { community, that work to qualify her as } \\
\text { a "proper" victim. }\end{array}$ & 116 \\
\hline $\begin{array}{c}\text { *REFERENCES/ } \\
\text { COMPARISONS TO } \\
\text { BLACK MALE VICTIMS }\end{array}$ & $\begin{array}{c}\text { References to other Black male victims } \\
\text { of police brutality and systemic anti- } \\
\text { Blackness. }\end{array}$ & 218 \\
\hline BLAME & $\begin{array}{l}\text { References that position blame for what } \\
\text { happened to Breonna Taylor to a } \\
\text { specific person(s)/event. }\end{array}$ & 27 \\
\hline BLM & $\begin{array}{l}\text { References to Black Lives Matter } \\
\text { activism. }\end{array}$ & 28 \\
\hline BREONNA'S LEGACY & $\begin{array}{l}\text { References/framing about the impact } \\
\text { Breonna Taylor has made on the justice } \\
\text { system and society. }\end{array}$ & 106 \\
\hline CELEBRITY ACTIVISM & $\begin{array}{c}\text { Articles framed around celebrity } \\
\text { activism in the name of Breonna } \\
\text { Taylor. }\end{array}$ & 69 \\
\hline $\begin{array}{l}\text { *CIVIL RIGHTS } \\
\text { REFERENCES }\end{array}$ & $\begin{array}{c}\text { References to the } 1960 \text { s Civil Rights } \\
\text { Movement. }\end{array}$ & 5 \\
\hline DELAY IN JUSTICE & $\begin{array}{l}\text { References made to the time delay in } \\
\text { moves towards justice for Breonna. }\end{array}$ & 18 \\
\hline DOUBLE DEATH & $\begin{array}{c}\text { References that position blame for } \\
\text { Breonna's death on Breonna or } \\
\text { Kenneth Walker, who were both } \\
\text { victims. }\end{array}$ & 15 \\
\hline FAILED RAID & & 194 \\
\hline HONORING BREONNA & $\begin{array}{l}\text { References to actions being taken in } \\
\text { order to honor Breonna Taylor and her } \\
\text { memory. }\end{array}$ & 53 \\
\hline *INACCURATE INFO & $\begin{array}{l}\text { Stated facts about the Breonna Taylor } \\
\text { case that were proven to be inaccurate. }\end{array}$ & 4 \\
\hline INNOCENCE & $\begin{array}{l}\text { References to Breonna's innocence as } \\
\text { a means to qualify her as a "true" } \\
\text { victim. }\end{array}$ & 71 \\
\hline $\begin{array}{l}\text { LACK OF POLICE } \\
\text { ACCOUNTABILITY }\end{array}$ & $\begin{array}{l}\text { References made to the fact that the } \\
\text { police officers who killed Breonna } \\
\text { Taylor have not been adequately } \\
\text { punished. }\end{array}$ & 45 \\
\hline
\end{tabular}




\section{LARGER GOVERNMENT CORRUPTION}

LMPD TAKE NO

RESPONSIBILITY

META-

COVERAGE/COVERAGE ABOUT THE PROTESTS

NATIONWIDE POLICING

PRACTICES

PERFORMATIVE JUSTICE

POLICE REFORM \& ACCOUNTABILITY

POLITICIAN ACTIVISM

RETALIATORY

VIOLENCE

SAY HER NAME

*STRIKETHROUGH

SYSTEMIC FAILURES

TAYLOR'S FAMILY

MEMBERS
Articles that frame what happened to

Breonna Taylor as a result of larger

government corruption and unethical behavior.

References to the Louisville Metro

PD's refusal to accept any

responsibility for Breonna Taylor's death.

Articles that reference the media

14

coverage of the Breonna Taylor case and protests.

Articles that examine U.S. policing

7

through Breonna Taylor's death as a framework.

References to political/legal actions

taken as a result of what happened to

Breonna Taylor that did not make a

material difference. These articles are

framed around informing us that justice

for Breonna is an empty joke.

References to police accountability and

72

reforms as a direct result of what happened to Breonna Taylor.

Articles framed around politicians

6

demanding justice for Breonna.

Articles that draw a direct line between

44

incidence of community violence and the Breonna Taylor case.

References to Say Her Name.

articles/results excluded from the study

sample based on relevance, type of

media (podcasts, news broadcasts and transcripts...), and duplicate articles.

References to systemic failures in the Breonna Taylor case.

Articles framed in the perspective of

Breonna's family and friends. 
APPENDIX B: BREONNA'S EMBEDDEDNESS IN THE NARRATIVE

\begin{tabular}{|cc}
\hline Embeddedness In the Article's Narrative \\
\hline & Frequency \\
\hline Paragraph 2 Mention & 7 \\
\hline Paragraph 3 Mention & 3 \\
\hline Paragraph 4 Mention & 1 \\
\hline Paragraph 6 Mention & 1 \\
\hline Paragraph 7 Mention & 2 \\
\hline
\end{tabular}

